UNIVERSIDADE DE SÃO PAULO

FACULDADE DE FILOSOFIA, LETRAS E CIÊNCIAS HUMANAS

DEPARTAMENTO DE FILOSOFIA

PROGRAMA DE PÓS-GRADUAÇÃO EM FILOSOFIA

SÉRGIO IZIDORO DE SOUZA

Organismo como finalidade segundo Kant 


\title{
Organismo como finalidade segundo Kant
}

\author{
(Versão Corrigida)
}

Tese apresentada ao Programa de PósGraduação de Filosofia da Faculdade de Filosofia Letras e Ciências Humanas da Universidade de São Paulo, para obtenção do título de Doutor em Filosofia sob a orientação do Prof. Dr. Maurício Cardoso Keinert. 
Autorizo a reprodução e divulgação total ou parcial deste trabalho, por qualquer meio convencional ou eletrônico, para fins de estudo e pesquisa, desde que citada a fonte.

Catalogação da Publicação Biblioteca Florestan Fernandes

Faculdade de Filosofia, Letras e Ciências Humanas da Universidade de São Paulo

Catalogação na Publicação

Serviço de Biblioteca e Documentação

Faculdade de Filosofia, Letras e Ciências Humanas da Universidade de São Paulo

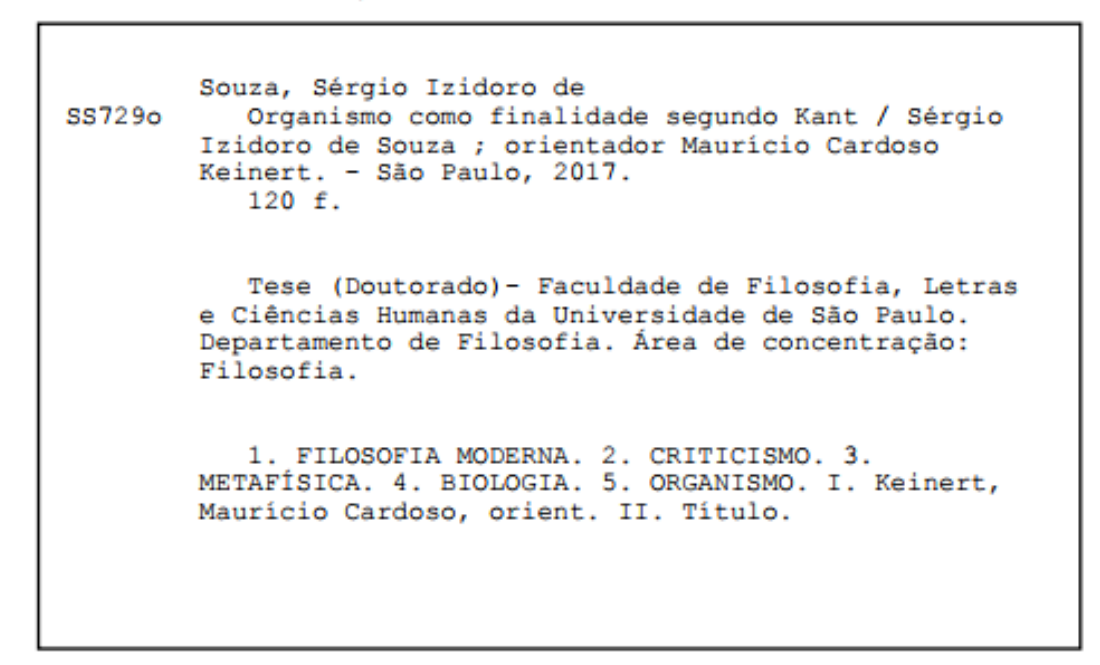


SOUZA, S.I. Organismo como finalidade segundo Kant - Faculdade de Filosofia, Letras e Ciências Humanas, Universidade de São Paulo, São Paulo, 2017. Tese apresentada à Faculdade de Filosofia, Letras e Ciências Humanas da Universidade de São Paulo.

Aprovado em:

Banca Examinadora

Prof(a). Dr(a). $\quad$ Instituição:

Julgamento:__ Assinatura:

Prof(a). Dr(a). Instituição:

Julgamento: Assinatura:

Prof(a). Dr(a).

Instituição:

Julgamento: Assinatura:

Prof(a). Dr(a )

Instituição:

Julgamento: Assinatura: 


\section{Agradecimentos}

Em primeiro lugar gostaria de agradecer ao Prof. Dr. Maurício Cardoso Keinert pela orientação sempre muito atenta e crítica aos meus textos, orientação essa que sem dúvida elevou muitíssimo as minhas qualidades de pesquisador. Gostaria também de agradecer aos Professores Doutores Pedro Paulo Pimenta e Fernando Costa Mattos pelos conselhos dados no exame de qualificação que foram muito valiosos para a próxima etapa da pesquisa. Além disso, gostaria de agradecer aos membros do Grupo Autonomia que discutiram e contribuiram com as inúmeras versões da tese: André Perez, Luiz Gonzaga, Quesidonis e Patrícia, Edilene, Adriana, Lara Pimentel, André Doneux, Rodrigo Tumolo e Rodrigo Andia, Daniel, Paulo, todos sem dúvida contribuíram muito. Também agradeço aos amigos de café, viagens e entretenimento, Elisabete Ferraz, Marcos (GL), Alex, Bruno, Jeferson, Nastasia, Francisco Denis, Michel, Pedro Rubro, Iremar, os uspianos do Grajaú, Francisco, Herodes, Marcelo Candeias, Otacílio, o professor Amir, e todos os outros que eu esqueci o nome. Sueli e Sonia pelo apoio de sempre, e Lubislava Todorova pelo carinho no período.

Por último, agradecemos a bolsa de doutorado concedida pelo CNPq sem a qual essa pesquisa não poderia ser realizada. 
Die Teleologie ist wie eine Dame, ohne die kein Biologe leben kann. Er scheut sich jedoch, mit Ihr in der Öffentlichkeit zu zeigen. Ernst Wilhelm von Brücke 


\section{RESUMO}

SOUZA, S.I. Organismo como finalidade segundo Kant - Faculdade de Filosofia, Letras e Ciências Humanas, Universidade de São Paulo, São Paulo, 2017.

Na teoria da experiência da terceira Crítica, Kant estabelece a articulação das três faculdades de conhecimento. A possibibilidade das coisas em geral, segundo o modelo da analítica do entendimento, está ainda sendo pensada pelas categorias, contudo, em conformidade com as leis do entendimento, estas mesmas coisas dotadas de formas particulares estão sendo pensadas pela legalidade da faculdade de julgar, e ao cabo a razão pensa a possibilidade da totalidade dessas formas arranjadas em ordem em vista de um sistema, segundo a dialética da razão. A partir dessa articulação entre as faculdades mentais em função da experiência, buscou-se determinar os conceitos que possibilitam pensar o organismo mostrando que o organismo é finalidade interna produzida por epigênese e pré-formação. Para pensar a possibilidade de articulação dessas duas teorias embriológicas da história da filosofia, Kant mobilizou conceitos do entendimento, da faculdade de julgar e da razão. A terceira Crítica operou uma série de deslocamentos e articulações conceituais para pensar o organismo. A contingência que era pensada pela razão é deslocada para a faculdade de julgar em sua "legalidade do contingente". A terceira Crítica ainda deslocou a produção do organismo da intenção divina para a espontaneidade natural tendo o princípio da finalidade interna como fundamento mental. Na medida do possível buscamos introduzir a lógica transcendental na representação do organismo, e por esse caminho revelamos que entre os seus conceitos estão a liberdade, a técnica, o sistema e a comunidade, sob os quais Kant articulou as opostas teorias da pré-formação e da epigênese.

Palavras-chave: Kant, organismo, crítica, teleologia, metafísica, biologia. 


\begin{abstract}
SOUZA, S.I. Organism as purposiveness according to Kant - Faculdade de Filosofia, Letras e Ciências Humanas, Universidade de São Paulo, São Paulo, 2017.
\end{abstract}

In the theory of experience of the third Critique, Kant establishes the articulation of the three faculties of knowledge. The possibility of things in general, according to the model of the analytic of the understanding, is still being thought by the categories, but in conformity with the laws of the understanding these same things endowed with particular forms are being thought by the lawfulness of the faculty of judgement, and finally reason thinks the possibility of the totality of these forms arranged in the order of a system, according to the dialectic of reason. From this articulation between the mental faculties for the experience, we tried to determine the concepts that make it possible to think the organism by showing that the organism is an internal purposiveness produced by epigenesis and pre-formation. In order to think about the possibility of articulating these two embryological theories of the history of philosophy, Kant mobilized concepts of the understanding, the faculty of judgement and reason. The third Critique operated a series of dislocations and conceptual articulations to think the organism. The contingency that was thought by reason is shifted to the faculty of judgement in its "lawfulness of the contingent". The third Critique still shifted the organism's production from divine intention to natural spontaneity by having the principle of internal purposiveness as a mental foundation. As far as possible we seek to introduce transcendental logic into the representation of the organism, and through this path we reveal that among its concepts are freedom, technique, system and community, under which Kant articulated the opposing theories of pre-formation and of epigenesis.

Keywords: Kant, organism, criticism, teleology, metaphysics, biology. 
SUMÁRIO:

Introdução

p. 10.

1. Finalidade, técnica e legalidade p. 15.

1.1. A legalidade da contingência na teleologia intencional da razão.......p. 15.

1.2. A legalidade da contingência na finalidade sem fim do juízo reflexionante

2. Finalidade, técnica e liberdade ........................................................ p. 30.

2.1. Finalidade e técnica: o caráter de produto.......................................... 30.

2.2. Liberdade como espontaneidade simples.......................................... 32.

2.3. O caráter próprio de liberdade da técnica da natureza............................ 39.

3.Finalidade, técnica e sistema ............................................................... 48.

3.1. Introdução no sistema das faculdades pelos conceitos de finalidade, técnica e sistema........................................................................................... 48.

3.2. Dedução da finalidade transcendental..............................................p. 63.

3.3. Sistema como princípio transcendental da pré-formação e de reprodução.......................................................................................p. 75.

4.Finalidade, técnica e comunidade ...................................................p. 98.

4.1. A finalidade interna assentada na comunidade ...................................p. 98.

4.2. A finalidade interna assentada na reciprocidade...............................p. 103.

Conclusão ….................................................................. p. 106. 


\section{INTRODUÇÃO}

Immanuel Kant concebeu uma ideia de organismo que conciliou as três principais doutrinas da Idade Moderna, a saber, mecanicismo, pré-formação e epigênese. A conciliação das três doutrinas se dá no §81, onde Kant dá continuidade à solução da antinomia entre mecanismo e finalismo, a partir do deficit recíproco das duas doutrinas e do princípio que se deve subordinar o mecanismo ao princípio teleológico. Kant então põe a questão: Qual espécie de teleologia? Uma que possa instrumentalizar e se misturar com o mecanismo sob a regra da subordinação. Entre as teleologias disponíveis à época, Kant descarta o ocasionalismo e preformacionismo individual, pois estes têm a pretensão de explicar a propagação dos organismos de modo sobrenatural, ou seja, o parentesco e a afinidade entre os organismos produzidos exclusivamente pelas mãos de deus sem qualquer participação da natureza. Ora, segundo Kant, a propagação epigenética tem a vantagem de propôr uma hipótese natural, mesmo que o problema da causa primeira tenha sido cortado, e apenas se leve em conta o processo de propagação, dado a impossibilidade de conhecimento teórico do suprassensível para explicar a causa da primeira organização. A confiança na propagação natural e não hiperfísica, para os naturalistas e filósofos do século XVIII, assentava nas anomalias dos organismos, nas monstruosidades, nos desvios e defeitos do sistema, pois o deus inteligente não cometeria tais erros no sistema da natureza. A doutrina da epigênese e pré-formação genérica defendida por Blumenbach e Kant foi pensada através de uma naturalização da produção dos organismos, isto é, a natureza os produz e é responsável pelas falhas no sistema. E se a natureza é antes de tudo mecânica, segundo a filosofia kantiana, então a possibilidade de pensar os organismos deve poder conciliar mecanismo e teleologia. 
Nosso trabalho será limitado a expor a união da teoria da preformação com a da epigênese. O principal argumento é que esta conciliação é feita sob uma formulação teleológica dupla sobre o organismo: se a causa teleológica é das partes ao todo, então, há uma auto-produção e epigênese; mas se a causa teleológica é o todo (do corpo orgânico) sobre suas partes, então há uma reprodução de formas mais gerais sobre o indivíduo orgânico a partir da clássica teoria da pré-formação.

Este método de solução da contradição entre teorias é comum na filosofia de Kant desde o seu primeiro trabalho em 1747. Seu método consiste em buscar a extensão e o limite de cada teoria e a introdução de uma delas nos espaços onde a primeira não alcança dentro do mesmo objeto. Nesse sentido então uma teoria pode dividir o espaço com outra teoria oposta. De acordo com este método, a epigênese complementa a preformação, isto é, aquilo que a preformação não puder explicar no organismo, a epigênese deve poder explicar. No $\$ 81$ da Crítica da faculdade de julgar, Kant afirma que o "sistema da epigênese (...) também pode ser chamado de sistema da pré-formação genérica"1. Buscaremos mostrar que essa união entre epigênese e pré-formação deve mobilizar uma rede de conceitos de origens diversas.

A teleologia que Kant emprega para refletir sobre o organismo é então dupla: a teleologia tradicional do todo às partes a partir da divisão lógica, que poderia remontar a Platão; e esta outra teleologia das partes para o todo a partir da composição, como auto-organização, a qual deve remontar a Aristóteles. Esta teleologia decorre da necessidade de naturalizar a teleologia, expressada no que Kant chama de "produto da natureza" (Naturprodukt), cuja fórmula é: "uma coisa existe como um fim natural se for causa e efeito de si". Aqui, a idéia de uma "causa e efeito de si" é introduzida para superar a externalidade da causa teleológica (teleologia

\footnotetext{
${ }^{1}$ KANT, I. Kritik der Urteilskraft, AA 05: 423.
} 
divina). Portanto, é necessário pensar a expressão "de si mesmo" (von sich selbst) como uma causa interna e não como uma repetição ou reprodução, mas como uma autoprodução. O exemplo da árvore coloca a tese de Kant de que há reprodução e autoprodução na espécie, no indivíduo e nas partes. O caso da autoprodução das partes é fundamental para a nossa tese, porque o exemplo dado por Kant é o da regeneração, que normalmente foi pensado pela pré-formação e reprodução. Mas Kant pensa-a através da epigênese e da autoprodução, porque a parte está sendo pensada como a causa do todo, e não o oposto, é por isso que ele enfatiza que essas partes não são idênticas a antes e podem ser ainda partes com "deformações" (Mißgestalten) após a regeneração, no entanto, elas possuem a mesma função de preservar o todo. Elas são autoproduzidas, porque o todo não é sua causa, mas seu efeito. A teoria kantiana do organismo articula epigênese e pré-formação pelos conceitos de finalidade, técnica, sistema, espontaneidade e comunidade. Os quatro primeiros conceitos estão presentes desde a Primeira Introdução à Crítica da faculdade de julgar, o conceito de comunidade não aparece diretamente, mas há muitas sugestões sobre ele nos textos de Kant.

O capítulo 1 trata de defender a ideia de que, na filosofia kantiana, a teleologia pode ser introduzida somente onde há contingência. Para isso mostramos que a introdução da causa final na Crítica da razão pura se dá pela teologia dentro do argumento da contingência do mundo e da físico-teologia, o qual já fora refutado e transformado em um argumento utilitarista, o de dar finalidade a tudo o que é produzido pela natureza da razão. Na Crítica da faculdade de julgar o argumento não é utilitarista, mas necessário, na medida em que o entendimento é provado como finito, abre-se a partir daí a possibilidade de uma contingência na experiência que torna-se território de outra faculdade mental. A solução de Kant para o problema da 
contingência aqui é então limitá-la à faculdade de julgar e ao seu princípio transcendental, a finalidade da natureza, e a conhecida fórmula na qual Kant afirma que a 'finalidade é a legalidade do contingente'.

A terceira Crítica ainda necessita deslocar a teleologia comprometida com a teologia para uma teleologia comprometida apenas com a física e a história natural, para isso Kant vê a necessidade de deslocar a causalidade do ideal da razão para a terceira antinomia cosmológica. Esse ponto nós trataremos no capítulo 2, onde mostramos que a solução da contingência do mundo pela introdução de um deus arquiteto da teleologia do mundo é superada na Crítica da faculdade de julgar pela introdução de uma liberdade na natureza atribuída a sua técnica espontânea, pensada aqui pela lacuna contingente entre entendimento e razão. $O$ capítulo 3 trata de mostrar que o organismo é pensado pelos conceitos de finalidade, técnica e sistema, e, sobretudo, que a ideia de sistema da Crítica da faculdade de julgar abandonará o argumento da segunda parte do Apêndice (sistema com teologia) e se aproximará da primeira parte do Apêndice (sistema e parentesco) e dos opúsculos sobre as raças, onde a causa do sistema natural não era um deus, mas uma providência da natureza, a qual será chamada de organização originária na Crítica da faculdade de julgar. No capítulo 4 nós defendemos a ideia mais difícil, mas defendida também por alguns poucos comentadores, que é a do conceito de comunidade na lógica do organismo. Nosso principal argumento é o da diminuição da função do conceito de sistema nos $\S \S 64$ e 65 e daí a necessidade de introdução do conceito de comunidade para preencher a lacuna do conceito de sistema. Kant empregava a ideia de finalidade interna desde o seu primeiro escrito de 1747, ela pode ser reconhecida nos opúsculos e no Apêndice à dialética transcendental. A técnica da natureza existe desde o Gebrauch, mas pensada pelo entendimento, a novidade da terceira Crítica é a 
redução da técnica ao juízo reflexionante. Com isso, Kant conciliará duas das mais reconhecidas teorias teleológicas da modernidade, a epigênese possibilitada pela faculdade de julgar e a sua técnica, e a pré-formação possibilitada pela razão e a sua ideia de sistema, serão as produtoras da finalidade interna que caracteriza os organismos. 


\section{CAPÍTULO 1. Finalidade, técnica e legalidade}

\subsection{A legalidade da contingência na teleologia intencional da razão}

Necessidade e contingência são categorias de modalidade e recebem um tratamento próprio enquanto princípios para a faculdade de juízo determinante nos postulados do pensamento empírico. Mas necessidade e contingência são pensados geralmente em ligação com as categorias de relação de causalidade e comunidade. A legalidade da necessidade tem como fundamento o conceito de causalidade do entendimento na segunda analogia da experiência, onde se afirma: "Princípio da sequência temporal segundo a lei da causalidade: Todas a mudanças acontecem segundo a lei da conexão de causa e efeito."2, a qual estabelece a conexão necessária entre as representações pelo categoria de causalidade condicionada pela série temporal e significa que toda mudança tem uma causa necessária anterior a ela.

Ora, o motivo de introdução de teleologia é a contingência relativamente ao entendimento, o qual em sua atividade de determinação deve pensar a natureza pela categoria de necessidade. A contingência na Dialética transcendental é originada a partir da suspensão das condições da sensibilidade, dado que o espaço e o tempo possibilitam uma necessidade condicionada, portanto, não cabe falar em tempo na causalidade final, como alguns comentadores, por exemplo, buscaram distinguir as duas pela possibilidade de reversão temporal. A tentativa da razão de encontrar os incondicionados para a ideia de mundo produz subjetivamente a ideia de um mundo em contingência, o qual justifica a introdução da teleologia pela teologia, na prova físico-teológica. Ora, trata-se, nesse caso, de uma contingência oriunda da suspensão da estética transcendental, e a sua legalidade será pensada nos termos da teologia como um mundo dotado de uma intenção absoluta. Na terceira Crítica, a

\footnotetext{
${ }^{2}$ KANT, I. Kritik der reinen Vernunft, A 189/B 232.
} 
contingência será introduzida pela impossibilidade de o entendimento determinar o particular enquanto tal, daí a introdução de um outro tipo de teleologia, a finalidade. Nesse caso, se deverá admitir uma mistura do conceito de técnica com uma certa noção de simultaneidade e comunidade pensada para além da terceira analogia da experiência ("lei da reciprocidade ou comunidade"). A finalidade será concebida como legalidade do contingente enquanto tal, isto é, o particular, em sua possibilidade de ser submetido a um conceito particular refletido. Comecemos pela contingência do mundo e só então depois a contingência do particular.

Segundo Konrad $\mathrm{Cramer}^{3}$, todos os leibnizianos alemães faziam a passagem da natureza à teologia pelo conceito de contingência, o que ficou conhecido como argumento da contingência do mundo. Kant passou uma grande parte da sua vida tentando compreender os detalhes do argumento até a sua refutação: "Não há dúvida que Kant teve como alvo desse argumento um teorema fundamental da metafísica leibnizo-wolffiana, a saber, o teorema: 'Todo mutável é contingente' (Omne mutabile est contingens. Baumgarten: Metaphysica §131; Wolff: Ontologia §296)."4 Segundo Kramer ainda, haveriam três conceitos de contingência: a "contingência empírica na existência dos fenômenos na medida que esses apresentam-se como mudanças"; a "contingência inteligível na existência das coisas em geral"; e a “contingência lógica na existência dos fenômenos e das coisas em geral". O autor mostra que Kant tentou provar que "não pode ser justificada uma passagem entre esses três conceitos" de contingência, e que na quarta antinomia "umas das suas teses fundamentais é que é impossível uma passagem analítica da contingência empírica à

\footnotetext{
${ }^{3}$ CRAMER, K. "Kontingenz in Kants 'Kritik der reinen Vernunft" in Probleme der "Kritik der reinen Vernunft": Kant-Tagung Marburg 1981, Burkhard Tuschling, de Gruyter, 1984.

${ }^{4}$ CRAMMER, K. "Kontingenz in Kants 'Kritik der reinen Vernunft"' in TUSCHLING, B. (ed.) Probleme der "Kritik der reinen Vernunft": Kant-Tagung Marburg 1981, p. 152.
} 
contingência inteligivel”, essa passagem era usada pelos metafisicos, e Kant a está inviabilizando.

A contingência não está restrita à quarta antinomia, ela está implícita em toda a crítica da cosmologia racional na Dialética transcendental. Algumas passagens das Reflexões sobre metafísica mostram como Kant via a unidade da cosmologia, essa unidade se dá no conceito de contingência. A citação seguinte mostra como Kant estava vendo em conjunto o mundo da Analítica e da Dialética, a necessidade conhecida pelos sentidos, a passagem à contingência ou acaso, e a introdução de ordem pela razão:

Conhece-se o curso do mundo através dos sentidos, e através da razão a ordem da natureza, e quanto maior a razão mais ordem se descobre. $\mathrm{Na}$ falta de razão tudo aparece como acaso (ou necessidade cega). A natureza é sempre um princípio de ordem. ${ }^{5}$

Kant distingue espécies de necessidade e contingência, a necessidade empírica pensada pelo entendimento e pela sensibilidade ainda admitem uma contingência pensada pela razão: "Algo acontece necessariamente, i.e., segundo o conceito empírico de necessidade, o qual admite ainda uma contingência segundo conceitos da razão."6 Não há dúvida pela Dialética transcendental, que esse tipo de contingência da razão será a contingência do mundo. Ora, a natureza pensada como necessária é possibilitada pelos conceitos de causalidade e comunidade. Mas a cosmologia racional ainda pode pensar a contingência do mundo e a comunidade de substâncias do mundo como contingente:

\footnotetext{
${ }^{5}$ Man erkennet den Lauf der Natur durch die Sinne, und durch die (Vernunft die) Ordnung der Natur; ie größer die Vernunft, desto mehr Ordnung entdekt man. Beym Mangel der Vernunft scheint alles Zufall (oder blinde Nothwendigkeit ). Die Natur ist iederzeit ein principium der Ordnung. (KANT, I. AA XVII, Reflexionen zur Metaphysik, p. 547)

${ }^{6}$ Etwas geschieht nothwendig, d.i. nach dem empirischen Begriffe der Nothwendigkeit, welches doch eine Zufalligkeit nach Begriffen der Vernunft zuläßt. (KANT, I. AA XVII, Reflexionen zur Metaphysik. p. 509)
} 
A composição de um todo de substâncias é uma prova da contingência. A limitação de cada coisa é uma prova da contingência. A mudança de cada coisa é uma prova da contingência. Se não a partir do espaço como fundamento da possibilidade da comunidade de substâncias segundo leis da sensibilidade à intuição de uma causa validamente concluída antes de todas as coisas que podem estar em comunidade. E a partir do tempo infinito como o fundamento de possibilidade da duração das coisas à eternidade e necessidade da causa. $^{7}$

Na mesma linha de raciocínio, a composição das partes para o todo, portanto a comunidade, é vista como contingente pela razão, que exige o inverso para que haja necessidade: "Todo comércio e portanto todo composto é enquanto tal contingente."» A contingência do mundo, ideia dialética, leva a razão a tomar esse mundo como dependente de causa necessária: "A composição prova a contingência (e dependência), pois um ser necessário não pode ser composto. A totalidade prova a dependência da unidade. A composição prova também a finitude." 9 Trata-se do argumento fundamental da cosmoteologia, o mundo tomado na sua forma a mais incondicionada é o mundo contingente, daí a passagem à teologia: “Cosmoteologia é construida na proposição: a primeira causa de uma coisa contingente é a partir de liberdade, não a partir da necessidade da sua natureza; primeiro motor, teleológico."10 A possibilidade de passar da experiência necessária ao mundo contingente está assentada na ideia de que se trata de uma necessidade condicionada

\footnotetext{
${ }^{7}$ Die composition eines totius substantiarum ist ein Beweis der Zufalligkeit; Die Einschränkung jedes Dinges ist ein Beweis der Zufalligkeit. Die Veränderung jedes Dinges ist ein Beweis der Zufalligkeit. $\mathrm{Ob}$ nicht aus dem Raume als dem Grunde der Möglichkeit des commercii der substantiarum nach Gesetzen der Sinnlichkeit auf die Anschauung einer vor alle Dinge, die in commercio stehen könen, gültigen Ursache könne geschlossen werden. Und aus der unendlichen Zeit als dem Grunde der Moglichkeit der Dauer der Dinge auf die Ewigkeit und nothwendigkeit der Ursache. (KANT, I. AA XVII, Reflexionen zur Metaphysik. p. 410)

8 Alles commercium und mithin alles compositum ist als solches zufällig. (KANT, I. AA XVII, Reflexionen zur Metaphysik. p. 534)

${ }^{9}$ Die composition beweiset die Zufälligkeit (und abhangigkeit ) denn nothwendige Wesen können nicht zusammengesetzt seyn. Die totalitaet beweiset die Abhängigkeit von Einem. Die Composition beweiset auch die finitudinem. (KANT, I. AA XVII, Reflexionen zur Metaphysik. p. 507)

${ }^{10}$ Cosmotheologie ist auf den Satz erbaut: die erste Ursache eines zufelligen Dinges ist es aus Freyheit, nicht aus der Nothwendigkeit seiner Natur; erster Beweger, teleologisch. (KANT, I. AA XVII, Reflexionen zur Metaphysik. p. 605)
} 
às condições da sensibilidade, o que na renúncia à "apreensão do múltiplo" (Apprehension des Mannigfaltigen) empírico leva ao incondicionado da contingência, que por sua vez leva ao incondicionado da necessidade de deus:

Toda necessidade e contingência que se pode representar é condicionada. A incondicionada é pensada problematicamente. Ambos, o absolutamente contingente (e.g. ação livre) e o absolutamente necessário, não se deixam pensar. ${ }^{11}$

A liberdade de deus é uma liberdade fora do mundo, isso para marcar a diferença da liberdade transcendental da terceira antinomia, a espontaneidade é uma liberdade negativa dentro do mundo. A ideia de mundo como sistema é uma ampliação máxima do conceito de corpo como massa: na primeira antinomia o mundo é um todo (quantidade), na segunda antinomia ele possui partes (qualidade), as quais, na terceira antinomia, estão em relação interna e se pergunta, não pela relação entre as partes, mas pela totalidade da causalidade, se mecânica ou livre. Aqui não pode ser comunidade, mas se poderia pensar em comunidade incondicionada, e por isso ainda não sistema, as antinomias deveriam ter solução dogmática para que se decidisse sobre a sistematicidade do mundo, como se sabe, a solução do Apêndice será outra.

Da contingência do mundo então os metafísicos faziam a passagem a existência da necessidade absoluta, o deus como ser necessário, e Kant refuta o argumento pela crítica da contingência intelectual. O argumento cosmológico consiste então em pensar que o mundo é contingente e precisa ter uma causa necessária. A fisico-teologia introduz as contingências nas próprias coisas e faz uso

\footnotetext{
${ }^{11}$ (Alle Nothwendigkeit und Zufalligkeit, die wir uns vorstellen können, ist bedingt. Die unbedingte ist problematisch gedacht. Schlechterdings zufallig (e. g. freye Handlung) und schlechterdings nothwendig lassen sich beyde nicht denken.) (KANT, I. AA XVII, Reflexionen zur Metaphysik. p. 260)
} 
então de uma prova empírica da existência de deus. A crítica da prova está na impossibilidade de apreender a totalidade empírica para passar à totalidade absoluta.

Na primeira apresentação da quarta antinomia, Kant trata de esclarecer em que sentido é possível antinomia para os conceitos de possível, efetivo e necessário, já que eles não cumprem a primeira vista a exigência da série, mas apenas:

"na medida em que o contingente na existência se deve sempre considerar condicionado, e segundo a regra do entendimento, nos remete para uma condição, que, por sua vez, nos remete necessariamente para uma condição mais elevada, até que a razão encontre na totalidade desta série a necessidade incondicionada." 12

A série completa dos fenômenos é ao cabo uma série contingente, há aqui sem dúvida um paralelo com a terceira antinomia, pois nesta, a série nos fenômenos era pensada como segundo o mecanismo, e introduzia-se a espontaneidade como causa primeira da série. Na quarta antinomia, o contingente condiocionado a uma condição conduz à necessidade incondicionada. Na representação da quarta antinomia, a antítese afirma que "Não há em parte alguma um ser absolutamente necessário, nem no mundo, nem fora do mundo, que seja a sua causa."13. A contingência no mundo foi introduzida, como se viu, pela razão na medida em que pensou a totalidade da série como condicionada, pois o entendimento pensa as partes da série como necessárias. Ora, a antítese da quarta antinomia cosmológica toma o mundo como contingente, não haveria no mundo ou fora dele qualquer ser absolutamente necessário. Para os nossos propósitos não há necessidade de expor toda a quarta antinomia em toda a sua extensão, estamos interessados apenas em descobrir a legalidade do contingente pela razão, a qual assenta na intencionalidade

\footnotetext{
${ }^{12}$ KANT, I. Crítica da razão pura, A 415 / B 442. Trad. M. P. Santos e A. L. Morujão.

${ }^{13}$ KANT, I. Crítica da razão pura, A 453 / B 481. Trad. M. P. Santos e A. L. Morujão.
} 
da razão, para alcançar isso nós nos espelhamos nos $\$ \S 76$ e 77 da terceira Crítica, onde a contingência é introduzida em uma limitação do entendimento discursivo, e legislada pela finalidade, conceito oriundo do procedimento técnico espontâneo da faculdade de julgar reflexionante.

Nosso interesse aqui é mostrar apenas a introdução da contingencia pela razão, na medida em que esta leva em consideração a totalidade da série como questão, para ver aí se a contingência comporta-se de modo idêntico ou não na dialética transcendental. No Apêndice, por exemplo, Kant não usou a contingência como parte da introdução da teleologia. A contingência é parte fundamental do argumento cosmológico e físico-teológico da existência de deus. A contingência no argumento cosmológico no Ideal da razão, não foge a esse procedimento da razão, isto é, o mundo é tomado em totalidade, como um existente, e esse existente como contingente conduz a uma causa necessária, deus. O argumento físico-teológico não parece seguir esse caminho, e foi provavelmente por essa diferença que ainda houve possibilidade de lidar com ele na terceira Crítica. Segundo Lebrun, o filósofo não teria analisado completamente essa prova, a nossa opinião é que a prova é descartada, mas o procedimento de prova é reaproveitado.

Kant, além disso, não parece estar introduzindo a contingência pela totalidade da série, mas pelo entendimento na observação empírica. Kant começa a sua crítica a prova físico-teológica apontando que a prova ontológica era uma prova pura assentada no conceito de "coisas em geral" (Dingen überhaupt); que a prova cosmológica tinha uma pretensa experiência em geral, e assentava em "uma experiência de uma qualquer existência em geral" (Erfahrung von irgendeinem Dasein überhaupt); e a prova físico-teológica começava pela física através de "uma experiência determinada, portanto, e de coisas do mundo presente" (eine bestimmte 
Erfahrung, mithin die der Dinge der gegenwärtigen Welt). Tal prova não é produzida puramente pela razão, pois seus passos iniciais se dão na experiência. Ora, Kant alerta que ideia nenhuma pode ter experiência: "É próprio de uma ideia,

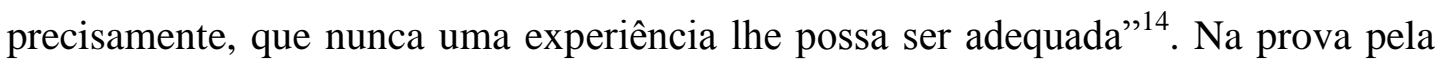
física, deus deveria pertencer a série das condições, mas ele não pertence, é preciso sair da série para pensá-lo, e então a prova pela experiência não está sendo válida. $O$ argumento começaria pela experiência física, passaria então a cosmologia, pensando o mundo em totalidade como finalidade, beleza e ordenação, e por fim a deus como causa desse mundo artesanal:

O mundo actual presente abre-nos um campo tão incomensurável de variedade, de ordem, de finalidade e de beleza, quer se considere na infinitude do espaço, quer na ilimitada divisão deste, que apesar dos conhecimentos que o nosso débil entendimento nele pôde adquirir, toda a linguagem é impotente para traduzir tantos e tão grandes prodígios. ${ }^{15}$

$\mathrm{O}$ argumento teleológico dogmático consistia em pensar um deus existente. $\mathrm{O}$ criticismo kantiano se descompromete com o argumento da existência, e deriva a teleologia das nossas faculdades de representação. O argumento de Kant na segunda parte do Apêndice à dialética transcendental rejeita a fundamentação pela prova da existência pelo que Kant chama de "razão perversa". A ideia de deus nesse caso é introduzida e sustentada pela ideia de unidade sistemática, a qual consiste em pensar que a razão pode introduzir teleologia no mundo colocando a ideia de fim como gênero supremo da unidade sistemática. Aqui a legalidade do contingente não se distingue da intencionalidade divina, a não ser pela vantagem de não depender do argumento físico-teológico.

\footnotetext{
${ }^{14}$ KANT, I. Crítica da razão pura, A 621 / B649. Trad. M. P. Santos e A. L. Morujão.

${ }^{15}$ KANT, I. Crítica da razão pura, A 622 / B650. Trad. M. P. Santos e A. L. Morujão.
} 


\subsection{A legalidade da contingência na finalidade sem fim do juízo reflexionante}

Na primeira Introdução à Crítica da faculdade de julgar, Kant introduz o conceito de finalidade formal como fundamento da finalidade estética e da finalidade orgânica. Na medida em que a forma particular é separada das determinações transcendentais da matéria legisladas pelo entendimento, se abrirá a possibilidade de a faculdade de julgar ser a legisladora das formas particulares na medida em que essas formas apresentem finalidades entre si (possibilidade de serem submetidas a um conceito comum, daí a aparência de terem sido produzidas por tal conceito). Ora, a distinção entre a finalidade apenas formal e a estética dar-se-á na submissão da forma ao sentimento, e na finalidade orgânica a forma será submetida a um conceito, o conceito de causa final. A forma legislada pela finalidade em suas três figuras será a forma contingente para o entendimento, vejamos como isso se dá, para ao cabo lançar alguma luz sobre a legalidade da finalidade.

É pela finitude do entendimento que se introduz a contingência no particular e torna-se o território (o das formas) da faculdade de julgar. O entendimento deve distinguir possibilidade e efetividade, pois se o nosso entendimento fosse intuitivo e não discursivo então não haveria diferença entre possibilidade e efetividade (posição da coisa em relação ao conceito; posição da coisa mesma além do conceito).

Para um entendimento sem essa distinção aconteceria o seguinte: todo os objetos que eu conheço existem; e a possibilidade de um não existir, isto é, contingência do mesmo se ele existir, portanto também algo distinto da necessidade, não seria possível a representação de um tal ser. ${ }^{16}$ Grifo nosso.

\footnotetext{
${ }^{16}$ Für einen Verstand, bei dem dieser Unterschied nicht einträte, würde es heißen: alle Objekte, die ich erkenne, sind (existieren); und die Möglichkeit einiger, die doch nicht existierten, d.i. Zufälligkeit derselben wenn sie existieren, also auch die davon zu unterscheidende Notwendigkeit, würde in die Vorstellung eines solchen Wesens gar nicht kommen können. KANT, I. Kritik der Urteilskraft, AA V: 403.
} 
Kant está montando um argumento por analogia. É por isso que ele discute a finitude discursiva do entendimento como abertura para a possibilidade de a razão buscar deus no téorico e liberdade no prático. O indicador de argumento analógico de Kant é o advérbio "Igualmente" "(Ebenso), o que lhe permite pensar que a finitude discursiva do entendimento igualmente abra a possibilidade para a técnica da natureza além do mecanismo da natureza. Kant então introduz a ideia de uma legalidade do contingente, ou seja, trata-se de pensar aqui que a finalidade é a legalidade do contingente ao entendimento. Essa legalidade é exigência da razão, pois esta exige que a lacuna deixada pelo entendimento seja preenchida, segundo o seu princípio da determinação completa, a faculdade de julgar reflexionante toma esse território para si, sem todavia poder determinar os objetos sob ela.

O $§ 77$ trata da propriedade do entendimento que possibilita a contingência, finalidade, técnica e sistema da natureza introduzidas via contingência no parágrafo anterior. Kant introduz a ideia de um outro entendimento diferente do nosso para possibilitar a reflexão sobre o nosso, isto é, um entendimento intuitivo para comparálo com um entendimento discursivo. A justificativa para isso é a mesma que foi utilizada para a distinção entre fenômeno e númeno, foi preciso pensar uma outra intuição (não sensível) para comparar com a nossa intuição sensível limitada ao campo dos fenômenos. O fato de o fundamento da finalidade estar em uma limitação do entendimento limita também a causalidade aí introduzida a ser apenas regulativa.

A contingência está, deste modo, no particular, pois a faculdade de julgar deriva o particular do universal do entendimento, mas esse universal do entendimento discursivo não determina o particular. Por determinação aqui se deve entender a determinação completa, princípio da razão que o entendimento não pode satisfazer, o particular não pode ter determinação completa. Assim, o particular é 
contingente na medida em que há infinitas maneiras para que ele possa ser determinado pelo universal, pois para o nosso entendimento discursivo (faculdade de conceitos) é contingente a multiplicidade de formas que o particular pode tomar, conceito nenhum pode prever essa multiplicidade.

Kant busca dar uma ideia do que seria o entendimento intuitivo. Trata-se apenas de uma comparação com outro entendimento como hipótese para mostrar que o nosso é distinto ${ }^{17}$. Uma intuição com espontaneidade completa seria um entendimento intuitivo, uma intuição que não obedece ao entendimento que vai do universal ao particular e singular. O entendimento intuitivo vai do universal-sintético (da intuição de um todo) ao particular, isto é, do todo às partes. O universal-analítico do entendimento discursivo é somente conceito, conceitos universais; o universalsintético do entendimento intuitivo é a totalidade do objeto, ou da natureza ou do mundo, daí a necessidade de uma intuição absolutamente espontânea. Nós não temos essa intuição livre, a qual seria um entendimento intuitivo, não podemos intuir senão das partes ao todo. O universal do entendimento aliado a intuição pelas partes faz então com que o mundo seja representado e conhecido mecanicamente, como relação de causa e efeito. A limitação do entendimento é o principal legitimador da contingência. A aliança entre universal analítico e intuição a partir das partes deixa indeterminado o múltiplo empírico para que a faculdade de julgar produza seus próprios conceitos, assim a contingência é possibilitada porque o todo empírico dos particulares, ou seja, as formas particulares não são intuíveis em totalidade, devem

\footnotetext{
${ }^{17}$ Es ist hiebei auch gar nicht nötig zu beweisen, daß ein solcher intellectus archetypus möglich sei, sondern nur, daß wir in der Dagegenhaltung unseres diskursiven, der Bilder bedürftigen, Verstandes (intellectus ectypus), und der Zufälligkeit einer solchen Beschaffenheit, auf jene Idee (eines intellectus archetypus) geführet werden, diese auch keinen Widerspruch enthalte. KANT, I. Kritik der Urteilskraft, AA V: 408.
} 
ser reconstruídas pelas faculdades de julgar, daí ela ter autonomia na legalidade do contingente.

Com isso passamos a definição de finalidade como legalidade do contingente. A fórmula se aplica tanto à finalidade formal quanto à finalidade real da natureza. A terceira Crítica desloca a contingência da razão para o meio-termo entre entendimento e razão ocupado pela faculdade de julgar, na medida em que a contingência está ligada ao particular indeterminado e não ao incondicionado da razão. Novamente a contingência é pensada em relação ao entendimento. Kant emprega essa fórmula em duas ocasiões, a primeira se dá na seção VI da Primeira Introdução: "finalidade é uma legalidade do contingente enquanto tal."18 A segunda ocorrência se dá no §76: "cuja legalidade do contingente chama-se finalidade"19 É sobretudo nas Introduções que é afirmado que a faculdade de julgar é legisladora na medida em que por parentesco e direito deve ser aceita entre as faculdades superiores e autônomas. A finalidade formal abre a possbilidade de sistematizar as leis empíricas, com isso é de se esperar que pela finalidade real as leis particulares do organismo devam igualmente ser sistematizáveis.

$\mathrm{Na}$ Analítica da faculdade de juízo teleológico, o conceito de contingência cumpre apenas dois papéis. O primeiro é no contexto da prova físico-teológica, já refutada na primeira Crítica. A terceira Crítica desenvolve a ideia de uma "teleologia da natureza" que não prova a existência de deus, mas possibilita um meio-termo na oposição entre o mecanismo da natureza e a prova moral da existência de deus. A teleologia natural não prova teoricamente a existência de deus, mas serve para confirmar a prova moral. O uso como prova teórica é infundado e Kant está então

\footnotetext{
${ }^{18}$ KANT, I. Erste Einleitung, AA XX: 217.

${ }^{19}$ KANT, I. Kritik der Urteilskraft, AA V: 404.
} 
revelando esse uso indevido da contingência: "para provar a contingência da mesma (da natureza) e sua forma" ${ }^{20} \mathrm{O}$ segundo papel do conceito de contingência, e é o que nos interessa, é o de justificar a introdução da razão como faculdade necessária para se pensar a natureza contra a insuficiência do entendimento: "Essa contingência da sua forma em todas as leis empíricas da natureza em relação à razão [...] é mesmo um fundamento para a admitir a causalidade da mesma como se ela fosse possível apenas pela razão." ${ }^{21}$ Como se vê, já aqui se pensa o organismo sob uma multiplicidade de leis ainda desconhecidas mas desejáveis, condição que justifica a introdução do princípio da finalidade, técnica e sistema para legislar sobre essa contingência através da pesquisa empírica. A faculdade de julgar legisla a contingência mas tem como meta a legislação do entendimento: "Essa contingência encontra-se completa e naturalmente no particular que a faculdade de julgar deve conduzir até o universal dos conceitos do entendimento. ${ }^{, 22}$.

O exemplo do hexágono, a outra ocasião no §64 em que Kant emprega o conceito de contingência, diz respeito a uma contingência encontrada na natureza que só é possível pela razão ("porque a contingência nele, com um tal conceito, só é possível na razão"23), no caso do hexágono somente um homem poderia tê-lo desenhado na areia pela sua técnica e inteligência. Trata-se nesse caso de uma legalidade da razão sobre a contingência. Os $\S \S 64$ e 65 não apresentam mais nenhuma ocorrência do conceito de contingência, e o seu uso foi sem dúvida o de mostrar a necessidade incortonável de fazer apelo à razão. Todavia, Kant introduz um problema na fundamentação pela razão, que é o de a causa ser exterior e hiperfisica, no que ele chama de "produto da arte", para que ela seja tomada como

\footnotetext{
${ }^{20}$ KANT, I. Kritik der Urteilskraft, AA V: 360.

${ }^{21}$ KANT, I. Kritik der Urteilskraft, AA V: 370.

${ }^{22}$ KANT, I. Kritik der Urteilskraft, AA V: 406.

${ }^{23}$ KANT, I. Kritik der Urteilskraft, AA V: 370.
} 
produto da natureza vai ser preciso tomar o fio condutor do juízo reflexionante, e por isso a contingência será submetida ao seu procedimento. O procedimento consiste em comparar os particulares para a produção de conceitos e leis empíricas, daí a transferência da contingência da razão para a faculdade de julgar.

Ainda há a presença do conceito de contingência na Dialética do juízo teleológico. Antes uma advertência: nossa interpretação da Dialética da faculdade de juízo teleológico não visa uma explicação extensa e sistemática dela como fazemos para os $\S \S 64$ e 65 da Analítica. Buscamos neste capítulo mostrar o problema da contingência, e para isso adentramos a Dialética. A diferença entre as ocorrências da categoria de contingência na Analítica e na Dialética está em que na primeira, a categoria de contingência é sobretudo o conceito de virada do mecanismo à autoprodução. Na Dialética, por sua vez, a contingência será objeto de discussão extensa e não apenas conceito de abandono do mecanismo. Em suma, consiste em pensar que se o entendimento aplica a categoria de contingência a um objeto, este então tem de ser pensado pela razão e a faculdade de julgar, e consequentemente a categoria de contingência tem de ser complementada pela ideia de fim da razão e de finalidade da faculdade de julgar.

A fórmula "finalidade é a legalidade do contingente" institui um território verdadeiramente independente aos domínios do entendimento e da razão. Com isso Kant também acaba mostrando que a categoria de contingência não é supérflua no entendimento, pois só essa faculdade pode reconhecer a contingência objetiva, mesmo que outras faculdades devam legislar sobre ela. A legislação da faculdade de juízo reflexionante consiste na forma de uma lei oriunda da comparação e sistematização empírica. Kant entende que a construção do objeto por esse caminho tem a forma técnica, isto é, a reunião de partes em vista de uma finalidade. O 
procedimento técnico da faculdade de julgar, na medida em que há ausência de conceito, e todavia um conceito não dado deve orientar a sua atividade, forma a ideia de uma autoprodução, daí que se deva pensar essa espécie de legislação como autolegislação. Técnica e finalidade sem fim são caracteres essenciais dessa legalidade do contingente, ao contrário da técnica intencional da razão. 


\section{CAPITULO 2. Finalidade, técnica e liberdade}

\subsection{Finalidade e técnica: o caráter de produto}

A concepção de organismo da terceira Crítica se distingue da primeira Crítica na medida em que nesta o organismo ainda era pensado apenas como "produto da arte". Na terceira Crítica, houve o esforço de concebê-lo como "produto da natureza" e para isso foram necessárias uma série de transformações conceituais. O ponto de vista do organismo como produto da arte é anterior ao período crítico, aqui são vencidos os obstáculos dogmáticos para pensá-lo além da técnica como uma técnica da natureza fundamentada na técnica do juízo reflexionante. Ora, na terceira Crítica, o conceito de produto ocupa uma posição semelhante ao de objeto na primeira Crítica, pois na mesma medida em que o objeto fora submetido às condições transcendentais das formas do espaço e tempo, categorias e ideias regulativas, também a construção do conceito de produto (da natureza e da arte bela) foi escrutinizada pela lógica da finalidade. Tanto para a bela arte quanto para o organismo valerá o mesmo conceito de produto como uma autoprodução.

A definição mais geral de finalidade encontra-se na Analitica do belo, onde “fim é o objeto de um conceito, na medida em que esse é visto como a causa daquele (o fundamento real da sua possibilidade)" ${ }^{24}$ A definição de produto em geral é a mesma de fim como "objeto de um conceito", na medida em que o conceito foi produzido como objeto.

Do outro lado da terceira Crítica a mesma presença chave do conceito de produção, por exemplo, na Analítica da faculdade de juízo telelógico, em uma crítica ao mecanicismo sustentada no conceito de produção contra o de movimento: "Em um relógio, uma parte é o instrumento de movimento da outra, mas uma roda não é a

${ }^{24}$ KANT, I. Kritik der Urteilskraft, AA V: 220. 
causa eficiente de produção da outra." ${ }^{25}$ Ou na Metodologia, onde o conceito ocasionalista de "produção" (Hervorbringung) dos organismos é criticado: "Se admite-se o ocasionalismo da produção de seres organizados, então toda a natureza é aqui perdida." ${ }^{26} \mathrm{O}$ conceito de produção, assim, é um conceito chave para a compreensão do organismo, e de tal modo que é preciso ir mesmo na primeira parte da obra, por exemplo, na definição de fim como causa de produção de uma obra: "Pois chama-se fim o efeito representado cuja representação é ao mesmo tempo o fundamento de determinação da causa eficiente inteligente para a sua produção."27. Esse efeito é o objeto que se dá o nome de arte, isto é, o fim é princípio de produção: "sem a regra pré-dada um produto nunca se chamaria arte",28

A arte bela deverá ter uma posição excepcional em relação a essa definição de arte como produto de causa conceitual. Pois a sua autonomia assentará na possibilidade de ela não se submeter a conceitos, daí que ela tenha de ter a forma de uma finalidade sem fim, como se fosse produzida por si mesma e sem uma finalidade determinada. Esse sentido de arte está em conformidade com o conceito de técnica da natureza terceira Crítica, como resultado de uma produção sem conceito determinante e tendo por isso a aparência de uma autoprodução. Arte e liberdade estão aqui sem dúvida em uma necessária aparência de identidade.

\footnotetext{
${ }^{25}$ In einer Uhr ist ein Teil das Werkzeug der Bewegung der andern, aber nicht ein Rad die wirkende Ursache der Hervorbringung des andern. KANT, I. Kritik der Urteilskraft, B374.

${ }^{26}$ Wenn man den Okkasionalism der Hervorbringung organisierter Wesen annimmt, so geht alle Natur hiebei gänzlich verloren. KANT, I. Kritik der Urteilskraft, B422.

27 Denn, die vorgestellte Wirkung, deren Vorstellung zugleich der Bestimmungsgrund der verständigen wirkenden Ursache zu ihrer Hervorbringung ist, heißt Zweck. KANT, I. Kritik der Urteilskraft, B426.

${ }^{28}$ ohne vorhergehende Regel ein Produkt niemals Kunst heißen. KANT, I. Kritik der Urteilskraft, B307.
} 


\subsection{Liberdade como espontaneidade simples}

A espontaneidade é liberdade sem intenção, portanto, uma causalidade que dá início a uma série, mas a falta-lhe um conceito do fim a atingir. Há aí uma diferenciação, como se vê, com o conceito geral de produção, o qual se define como o objeto de um conceito como causa. O problema com a espontaneidade é que Kant estipula apenas dois tipos de causalidade, a do entendimento e a da razão, então teria que ser possível violar essa restrição do $§ 65$ e admitir a espontaneidade como uma causa intermediária, ou como causalidade sem necessidade, como causalidade do contingente. Que a espontaneidade deva ser tomada ao menos hipoteticamente como causalidade é uma sugestão do $\$ 78$, o último da Dialética da faculdade de juízo teleológico, e onde Kant introduz o conceito de espontaneidade no organismo:

assim, é igualmente necessário para ela pensar um tipo especial de causalidade que não se encontra na natureza, já que a mecânica das causas naturais tem a sua própria, mas para a receptividade de muitas e diferentes formas com a qual a matéria é capaz segundo a última, deve introduzir ainda uma espontaneidade de uma causa (que portanto não pode ser matéria), sem a qual não poderia dar nenhum fundamento daquelas formas. ${ }^{29}$ Grifo nosso.

Temos, por isso, motivos para introduzir e diferenciar a espontaneidade da liberdade prática, a qual é uma liberdade sob conceitos e por isso deve ser compreendida como autodeterminação. A ideia de espontaneidade ${ }^{30}$ tem como

\footnotetext{
${ }^{29}$ so ist es eben so notwendig für sie, eine besondere Art der Kausalität, die sich nicht in der Natur vorfindet, zu denken, als die Mechanik der Naturursachen die ihrige hat, indem zu der Rezeptivität mehrerer und anderer Formen, als deren die Materie nach der letzteren fähig ist, noch eine Spontaneität einer Ursache (die also nicht Materie sein kann) hinzukommen muß, ohne welche von jenen Formen kein Grund angegeben werden kann. KANT, I. Kritik der Urteilskraft, B411.

${ }^{30}$ Marc Zobrist chama essa investigação pré-crítica de Kant de "metafísica do eu" dos anos 1770, o fundamento disso está no conceito de substância que está por trás da teoria kantiana do sujeito e da intersubjetividade, isto é, a espontaneidade e receptividade da substância. "Para o sujeito finito, o problema apresenta-se na medida em que possui também sempre um lado receptivo, de tal modo que não age apenas espontaneamente a partir de si, mas também, como na metafísica leibnizo-wolffiana, em conexão com as outras substâncias." ZOBRIST, M. Subjekt und Subjektivität in Kants theoretischer Philosophie: Eine Untersuchung zu den transzendentalphilosophischen Problemen des
} 
referência a terceira antinomia. Ora, a espontaneidade é independência (Unabhängigkeit), indeterminação e contingência, e não ainda a liberdade da razão prática, e por isso ela pode ser usada como um meio termo entre natureza e liberdade. A definição de espontaneidade na terceira antinomia a toma como uma causalidade primeira, independente de causa anterior, como a primeira de uma série que se inicia por si mesma:

Segundo isso, deve ser admitida uma causalidade através da qual algo acontece sem que a causa seja determinada segundo leis necessárias através de outra causa precedente, isto é, uma espontaneidade absoluta da causa, uma série de fenômenos que corre segundo leis naturais iniciadas de si mesmas, portanto, liberdade transcendental, sem a qual, no curso da natureza, a série de fenômenos do lado das causas nunca seria completa. $^{31}$

Kant identifica espontaneidade e liberdade transcendental, e desta passa a liberdade prática que ele define como: "A liberdade no sentido prático é a independência do arbítrio da necessitação pelo impulso da sensibilidade." ${ }^{32} \mathrm{O}$ essencial aí é a independência em relação à sensibilidade. A liberdade transcendental ou espontaneidade é a independência em relação à série causal condicionada pelo tempo, daí a capacidade de auto iniciar um estado:

entendo por liberdade no sentido cosmológico a capacidade de auto iniciar um estado, cuja causalidade assim não assenta na lei da natureza segundo a qual uma causa está sob outra causa, que é determinada segundo o tempo. ${ }^{33}$

Selbstbewusstseins und Daseinsbewusstseins. p. 12. Além disso, o conceito de espontaneidade tem origem em Aristóteles nos juízos não deliberados, ou seja, em juízos espontâneos. Cf . Marco Sgarbi

${ }^{31}$ Diesem nach muß eine Kausalität angenommen werden, durch welche etwas geschieht, ohne daß die Ursache davon noch weiter, durch eine andere vorhergehende Ursache, nach notwendigen Gesetzen bestimmt sei, d.i. eine absolute Spontaneität der Ursachen, eine Reihe von Erscheinungen, die nach Naturgesetzen läuft, von selbst anzufangen, mithin transzendentale Freiheit, ohne welche selbst im Laufe der Natur die Reihenfolge der Erscheinungen auf der Seite der Ursachen niemals vollständig ist. KANT, I. Kritik der reinen Vernunft, A446 /B474.

${ }^{32}$ Die Freiheit im praktischen Verstande ist die Unabhängigkeit der Willkür von der Nöthigung durch Antrieb der Sinnlichkeit. KANT, I. Kritik der reinen Vernunft, A534 / B562.

${ }^{33}$ verstehe ich unter Freiheit, im kosmologischen Verstande, das Vermögen, einen Zustand von selbst anzufangen, deren Kausalität also nicht nach dem Naturgesetze wiederum unter einer anderen Ursache steht, welche sie der Zeit nach bestimmte. Die Freiheit ist in dieser Bedeutung eine reine 
Kant emprega a ideia de espontaneidade em toda a filosofia transcendental. Por exemplo, segundo Marcus Willaschek ${ }^{34}$, haveria uma dependência da Analítica em relação a Dialética, pois o argumento da espontaneidade na dialética é um pressuposto da espontaneidade do entendimento na analítica, a faculdade legisladora da natureza: “As leis universais do entendimento, as quais são ao mesmo tempo leis da natureza, são tão necessárias (embora geradas a partir de espontaneidade) quanto as leis do movimento da matéria" ${ }^{\text {35 }}$. Kant faz uso dela na Analítica Transcendental para caracterizar o entendimento como faculdade espontânea.

Que as funções lógicas do juízo são o fundamento comum do nosso conhecimento dos objetos no espaço e no tempo conforme o entendimento de um lado, e das nossas determinações da vontade do outro lado, isso explica-se porque elas são expressão da mesma espontaneidade $^{36}$

Já na seção Ideia de uma lógica transcendental da primeira Crítica, Kant define as faculdades superiores de conhecimento de "espontaneidade dos conceitos", e as inferiores de receptividade:

Nosso conhecimento desprega-se de duas fontes fundamentais da mente, das quais a primeira é a capacidade de sentir as representações (a receptividade das impressões), a segunda a capacidade de conhecer um objeto através dessas representações (espontaneidade dos conceitos); pela primeira um objeto nos é dado, pela segunda é

transzendentale Idee, die erstlich nichts von der Erfahrung Entlehntes enthält, KANT, I. Kritik der reinen Vernunft, A533 / B561.

34 WILLASCHEK, M. "Die 'Spontaneität des Erkenntnis'. Über die Abhängigkeit der 'Transzendentalen Analytik' von der Auflösung der Dritten Antinomie” in: J. Chotas, J. Karásek, J. Stolzenberg (ed.): Metaphysik und Kritik. Interpretationen zur 'Transzendentalen Dialektik' der Kritik der reinen Vernunft, p. 165 e sgs.

${ }^{35}$ Die allgemeinen Gesetze des Verstandes, welche zugleich Gesetze der Natur sind, sind derselben eben so notwendig (obgleich aus Spontaneität entsprungen), als die Bewegungsgesetze der Materie. KANT, I. Kritik der Urteilskraft, B186.

36 "Dass die logischen Urteilsfunktionen der gemeinsame Grund unserer verstandesmässigen Erkenntnis von Gegenständen in Raum und Zeit einerseits und unserer Willensbestimmungen andererseits sind, erklärt sich dadurch, dass sie Ausdruck ein und derselben Spontaneität sind." Cf. KLEMME, H. F. "Spontaneität und Selbsterkenntnis : Kant über die ursprüngliche Einheit von Natur und Freiheit im Aktus des 'Ich denke' (1785-1787)" in Sind wir Bürger zweier Welten: Freiheit und moralische Verantwortung im traszendentalen Idealismus, Meiner, 2012, p. 196. 
pensado em relação àquela representação (como mera determinação da mente). ${ }^{37}$

Mais a frente ele especifica a faculdade de conhecimento como sendo o entendimento, e dotado de uma espontaneidade produtora (hervorzubringen) de conhecimento: “então, ao contrário, a capacidade de produzir as representações mesmas, ou a espontaneidade do conhecimento, é o entendimento"38 Aqui não é o lugar para desenvolver isso, o problema diz respeito a teoria de Kant de que o "eu penso" não é originado empiricamente, também não é derivado de algum conceito, ou determinado teleologicamente, mas fruto de uma mera espontaneidade. Mas se aí Kant identificava a espontaneidade com o entendimento, na Antropologia de um ponto de vista pragmático de 1798 , ele a identifica com a reflexão, o que deve significar que a espontaneidade engloba todas as faculdades de conhecimento superiores:

Se representamos a ação interna (espontaneidade) pela qual um conceito (um pensamento) se torna possível - reflexão -, e a susceptibilidade (receptividade) por meio da qual se torna possível uma percepção (perceptio), isto é, a intuição empírica - apreensão - , ambos atos, porém, com consciência, a consciência de si mesmo (apperceptio) pode ser dividida na consciência da reflexão e na da apreensão. A primeira é uma consciência do entendimento, a segunda, do sentido interno; aquela é a apercepção pura, esta a empírica, aquela sendo erroneamente chamada de sentido interno. p. 34.

Mas a espontaneidade não se limita ao sujeito do conhecimento e ao sujeito da ação, ela se estende ao sujeito da estética:

\footnotetext{
37 Unsere Erkenntnis entspringt aus zwei Grundquellen des Gemüts, deren die erste ist, die Vorstellungen zu empfangen (die Rezeptivität der Eindrücke), die zweite das Vermögen, durch diese Vorstellungen einen Gegenstand zu erkennen (Spontaneität der Begriffe); durch die erstere wird uns ein Gegenstand gegeben, durch die zweite wird dieser im Verhältnis auf jene Vorstellung (als bloße Bestimmung des Gemüts) gedacht. KANT, I. Kritik der reinen Vernunft, A 50 / B74.

38 so ist dagegen das Vermögen, Vorstellungen selbst hervorzubringen, oder die Spontaneität des Erkenntnisses, der Verstand. KANT, I. Kritik der reinen Vernunft, A 51 / B75.
} 
A espontaneidade no jogo das capacidades de conhecimento, cuja concordância contém o fundamento desse prazer, capacita o conceito pensado para a mediação da conexão do domínio do conceito de natureza com o conceito de liberdade nas suas consequiências, pois a liberdade exige ao mesmo tempo a receptividade da mente para o sentimento moral. ${ }^{39}$

O conceito não é exclusivo, como muitos outros na terceira Crítica, da reflexão sobre o organismo, pois também a arte bela é refletida através de alguma ideia de espontaneidade. A espontaneidade no jogo das faculdades constitui a passagem entre os dois domínios, o que por sua vez é espontaneidade de jogo entre entendimento e razão. Mas se a liberdade tem origem sempre na terceira antinomia, e se ela é encontrada e pensada em outros lugares é sempre porque há um parentesco ou afinidade entre elas que possibilita o deslocamento:

A espontaneidade no jogo da capacidades de conhecimento cuja concordância contém o fundamento dessse prazer torna possível o conceito pensado para a mediação da conexão do domínio do conceito de natureza como o conceito de liberdade em suas consequências. ${ }^{40}$

Ao que tudo indica, a espontaneidade é uma ideia da razão aplicável às outras faculdades mentais, o que nos autoriza já suficientemente a atribuí-la à faculdade de juízo reflexionante. Lehmann, por exemplo, usa a expressão "espontaneidade organizadora" emprestada de Grayeff ${ }^{41}$, o que é uma sugestão forte para ao menos relacionar espontaneidade e sistema. No contexto da dedução transcendental, a espontaneidade significa que o conhecimento não é determinado nem ante (inatismo)

\footnotetext{
${ }^{39}$ Die Spontaneität im Spiele der Erkenntnisvermögen, deren Zusammenstimmung den Grund dieser Lust enthält, macht den gedachten Begriff zur Vermittelung der Verknüpfung der Gebiete des Naturbegriffs mit dem Freiheitsbegriffe in ihren Folgen tauglich, indem diese zugleich die Empfänglichkeit des Gemüts für das moralische Gefühl befördert. KANT, I. Kritik der Urtheilskraft, AA V: 197.

${ }^{40}$ Die Spontaneität im Spiele der Erkenntnisvermögen, deren Zusammenstimmung den Grund dieser Lust enthält, macht den gedachten Begriff zur Vermittelung der Verknüpfung der Gebiete des Naturbegriffs mit dem Freiheitsbegriffe in ihren Folgen tauglich KANT, I. Kritik der Urtheilskraft, AA V: 197.

${ }^{41}$ LEHMANN, G. Beiträge zur Geschichte und Interpretation der Philosophie Kants, p. 162.
} 
nem post (empirismo), mas por uma certa autonomia cognitiva, onde as categorias são originadas por aquisição a priori. $\mathrm{O}$ mesmo deve valer para o organismo, como sendo tomado como uma espécie de natureza intermediária entre mecanismo e liberdade, e entre entendimento e razão.

A espontaneidade é a base de toda a subjetividade transcendental, e ela se auto-organiza com a razão formando uma teleologia interna: "A caracterização kantiana da espontaneidade do pensamento através da reflexão deixa-se fazer inteligível na ligação com a compreensão teleológica da razão enquanto condição subjetiva do conhecimento." 42 Essa auto-organização da espontaneidade possui uma relação de complementaridade nas Críticas $\left(1^{\mathrm{a}}\right.$ e $\left.3^{\mathrm{a}}\right)$ : “A teleologia interna na espontaneidade do pensamento forma como que uma fundamentação epistêmica comum da $\mathrm{KrV}$ e KU."43

Como se vê, a espontaneidade é definida como uma espécie de causalidade, e nesse contexto como uma causalidade da razão. Kant, então, deslocou a derivação do organismo da teologia para a cosmologia.

Ora, do ponto de vista do entendimento, todo movimento na experiência tem que ter uma causa externa, mas para os movimentos sem causa externa experienciável é necessário pensar uma causalidade interna que pode ser conforme a espontaneidade da faculdade de julgar ou conforme o dever ser da razão.

Em todos os casos de aparecimento da espontaneidade no sujeito se faz presente o mesmo sentido, trata-se de uma atividade livre mas não determinada por

\footnotetext{
${ }^{42}$ Die Kantische Charakterisierung der Spontaneität des Denkens durch die Reflexion läßt sich in Verbindung mit der teleologischen Auffassung der Vernunft als subjektive Bedingung des Erkennens verständlich machen. JENG, J.-J. Natur und Freiheit: Eine Untersuchung zu Kants Theorie der Urteilskraft, p. 32.

${ }_{43}$ Die innere Teleologie in der Spontaneität des Denkens bildet gleichsam eine gemeinsame epistemische Grundlage der KrV und KU. JENG, J.-J. Natur und Freiheit: Eine Untersuchung zu Kants Theorie der Urteilskraft, p. 211.
} 
conceito prévio, trata-se assim de uma concepção de espontaneidade idêntica a de finalidade sem fim, onde o produto é produzido por uma causalidade teleológica todavia sem telos prévio. É possivelmente por esse motivo que Kant afirme que a filosofia deve determinar os fins da razão humana, já que a subjetividade produz-se por espontaneidade. A espontaneidade, por isso, se adequa precisamente ao procedimento do juízo reflexionante de ser produzido sem conceito (para aplicação ao objeto). O juizo reflexionante tem por isso a forma de uma emergência.

A espontaneidade tem a sua dedução metafísica na razão, na terceira antinomia. Mas, apesar de ser uma ideia da razão, ela é aplicada às outras faculdades de conhecimento, trata-se dessa psicologia mínima de Kant em função da filosofia transcendental. $\mathrm{O}$ entendimento produz as categorias por espontaneidade, e daí em diante ele se torna uma faculdade de conceitos. Mas a faculdade superior que mais se adequa a forma da espontaneidade é a faculdade de julgar, não parece sem motivo que o erro se encontre nela. Nós buscamos mostrar que a ideia de espontaneidade é produzida pela razão, mas que as outras faculdades produzem por espontaneidade, e a que mais se caracteriza por ela é a reflexão como uma atividade incontornavelmente espontânea, talvez seja por isso que Kant afirme que os animais também fazem reflexão, mas guiada pelo instinto. 


\subsection{O caráter de produto natural livre}

A Analítica do juízo teleológico trata de justificar o emprego de teleologia no conceito de organismo, há aqui a concepção jurídica de dedução como procedimento de justificação. O $\$ 64$ introduz finalidade, técnica e liberdade na ideia de organismo. O $§ 65$ atribuirá essa tríade de conceitos a uma espécie de primado das partes sobre o todo e então surgirá a necessidade de introduzir o conceito de comunidade; e o $\$ 66$ trabalhará uma espécie de fundamentação a priori no conceito de sistema. A nossa interpretação do $\S 64$ então enfatizará o conceito de liberdade. Para Kant, um ser organizado deve ter como primeira exigência de conceitualização que a sua possibilidade de existência não seja pensada pela causalidade do entendimento, a causa eficiente, mas por uma causa através de conceitos, ou seja, a causalidade da razão, a liberdade. Aqui já se fala em liberdade como a causalidade da razão sobre a vontade. Kant então introduz um exemplo de finalidade e técnica, neste exemplo a liberdade está ausente. Trata-se do exemplo do hexágono desenhado na areia, ele cumpre a exigência de ser final e técnico quando penso a causa ou a "unidade do princípio de geração" (Einheit des Prinzips der Erzeugung), mas não livre, pois o hexágono não se produziu por si mesmo, mas por uma causa externa, um ser humano, sintetizada na expressão "vejo o rastro de homens" (vestigium hominis video). Assim pensada, há um problema com a finalidade, ela é uma causa exterior ao produto e conduz a alguma hiperfísica, não é portanto uma finalidade da natureza, mas uma técnica não-natural. Kant então introduz uma segunda condição, a ideia de "causa de si", que na sua filosofia pode apenas ser uma variação da ideia de liberdade. A árvore será o exemplo dessa espécie de liberdade natural, Kant nos remeterá a uma certa observação empírica de que a árvore é causa livre da sua espécie, dos seus indivíduos e de suas partes. 
Ora, uma série de comentadores de Kant pensam o organismo pelo conceito de autonomia $^{44}$, e ainda há os filósofos que tomam a autoprodução como autonomia $^{45}$, liberdade ${ }^{46}$, espontaneidade e vida ${ }^{47}$. Kant é o precursor dessa perspectiva que identifica liberdade, espontaneidade e vida, na qual o não-mecânico e assim a contingência estariam sob a tutela da terceira antinomia. Entre esses comentadores está Jyh-Jong Jeng, para quem o princípio transcendental da finalidade da natureza representa a natureza como um sistema produzido pela sua técnica, a qual é derivada da técnica do juízo reflexionante "mediante a heautonomia (autolegalidade) da faculdade de juízo reflexionante, a autonomia do entendimento e a autonomia da razão em si" ${ }^{48}$. Kant estaria então legitimando o emprego da ideia de liberdade na natureza:

A passagem da natureza à liberdade pode ser feita compreensível em verdade pela finalidade da natureza, na medida em que um novo conceito de uma natureza livre e inteligente deve ser admitido hipoteticamente. $^{49}$

A espontaneidade aparece nos $\S \S 64$ e 65 da Analítica da faculdade de juízo teleológico na definição de organismo: "uma coisa existe como fim da natureza se é

44 GENOVA, A. C. "Kant's epigenesis of pure reason”. Kant-Studien, Berlin, 65, p. 259-73, 1974; ZAMITTO, J. "Teleology Then and Now: the Question of Kant's Relevance for Contemporary Controversies over Function in Biology". In: Studies in History and Philosophy of Biological and Biomedical Sciences 37.4. 2006, 759.

${ }^{45}$ Cf. MORENO, A. e MOSSIO, M. Biological Autonomy: A Philosophical and Theoretical Enquiry; WEBER, A. e VARELA, F.J. "Life after Kant: Natural purposes and the autopoietic foundations of biological individuality" in Phenomenology and the Cognitive Sciences.

${ }^{46}$ Para Hans Jonas, o "metabolismo" (Stoffwechsel), enquanto "troca de matéria", une organismo e mundo externo, segundo Jonas, haveria no organismo uma espécie de dever de metabolizar que consistiria na liberdade do organismo: "Essa é a antinomia da liberdade na raiz da vida e em sua forma mais elementar, a do metabolismo mesmo." JONAS, H. Organismus und Freiheit: Ansätze zu einer philosophischen Biologie, p. 132.

${ }^{47}$ LEBRUN, G. Kant e o fim da metafísica

48 Dieses Weltprinzip vereinigt mittels der Heautonomie (Selbstgesetzlichkeit) der reflektierenden Urteilskraft die Autonomie des Verstandes und der Vernunft in sich. JENG, J-J. Natur und Freiheit: Eine Untersuchung zu Kants Theorie der Urteilskraft p. 5

49 Der Übergang von der Natur zur Freiheit kann zwar durch die Zweckmäßigkeit der Natur verständlich gemacht werden, indem ein neuer Begriff von der freien und verständigen Natur hypothetisch angenommen werden darf. JENG, J-J. Natur und Freiheit: Eine Untersuchung zu Kants Theorie der Urteilskraft p. 119. 
causa e efeito de si mesma (embora em duplo sentido)" ${ }^{\text {,5 }}$ Kant exemplifica essa espontaneidade através da árvore, nas observações de que "ela se autoproduz segundo a espécie" (erzeugt er sich selbst der Gattung nach); de que "uma árvore também se autoproduz como indivíduo" (erzeugt ein Baum sich auch selbst als Individuum); e de que "cada parte dessa criatura também se autoproduz" (erzeugt ein Teil dieses Geschöpfs auch sich selbst). Como se vê, Kant passou do paradigma técnico para o da espontaneidade, mas não excluiu aquele. Isso se pode confirmar no trecho sobre a autoprodução do indivíduo, no qual Kant reafirma a tese de que se deve pensar o organismo pelo conceito de produção, mas que no caso do organismo “é encontrada uma tal originalidade da capacidade de separação e formação nesse tipo de ser natural, de tal modo que toda arte permanece infinitamente distante" ${ }^{, 51}$.

A liberdade do juízo, segundo a sua dedução, é a finalidade sem fim, e como a liberdade é ideia da razão, então essa liberdade do juízo deve se limitar a uma finalidade espontânea, enquanto a da razão é uma finalidade intencional. Há aqui um parentesco lógico ou ainda mental entre espontaneidade e liberdade no conceito de fim, e talvez entre comunidade e sistema no conceito de totalidade, assim como na obra de arte um certo parentesco entre jogo e espontaneidade e vida no conceito de finalidade sem fim.

E então surge a questão: liberdade de que? Kant fala em "formação livre" (freie Bildung), mas se deve contar além de formas livres também relações e funcionamentos livres, ou seja, para a fisiologia e para a morfologia também se deve levar em conta alguma espontaneidade.

\footnotetext{
${ }^{50}$ ein Ding existiert als Naturzweck, wenn es von sich selbst (obgleich in zwiefachem Sinne) Ursache und Wirkung ist. KANT, I. Kritik der Urteilskraft, AA V: 370.

51 eine solche Originalität des Scheidungs- und Bildungsvermögens dieser Art Naturwesen anzutreffen, daß alle Kunst davon unendlich weit entfernt bleibt, KANT, I. Kritik der Urteilskraft, AA $\mathrm{V}: 370$.
} 
Lebrun identifica espontaneidade e vida, vejamos como isso é possível. $\mathrm{Na}$ "Mecânica" dos Princípios metafísicos da ciência da natureza, Kant define inércia como o contrário de vida. O conceito de inércia é derivado da categoria de substância, na medida em que o esquematismo da substância - a permanência - é pensada em sua possibilidade de construção, a permanência é tomada nessa obra como inércia da matéria, que é o estado de permanência de movimento ou repouso da matéria desde que não haja causa de mudança do estado, que é o princípio da Segunda Analogia.

Ora, na crítica dirigida a Newton e Kepler contra a concepção de inércia como força de permanência, e não como estado, Kant denuncia o animismo na concepção newtoniana, na medida em que inércia e vida seriam idênticas, o que não pode ser o caso na perspectiva kantiana, pois apenas seres vivos possuem força para se manter no mesmo estado ou alterá-lo. O problema da definição newtoniana de inércia, um certo vitalismo misturado a ela, leva Kant a definir vida, e neste o de liberdade:

A inércia da matéria é e significa nada senão sua ausência de vida como matéria em si mesma. Vida se chama a capacidade de uma substância de agir por si a partir de um princípio interno, de uma substância finita por si à mudança, e de uma substância material de determinar-se ao movimento ou repouso como mudança do seu estado. Ora, não conhecemos outro princípio interno de uma substância de mudar seu estado que o desejo e em geral nenhuma outra atividade interna senão o pensamento com o que aí depende, sentimento de prazer ou desprazer e apetite ou vontade. ${ }^{52}$

\footnotetext{
${ }^{52}$ Die Trägheit der Materie ist und bedeutet nichts anders, als ihre Leblosigkeit als Materie an sich selbst. Leben heißt das Vermögen einer Substanz, sich aus einem inneren Princip zum Handeln, einer endlichen Substanz, sich zur Veränderung, und einer materiellen Substanz, sich zur Bewegung oder Ruhe als Veränderung ihres Zustandes zu bestimmen. Nun kennen wir kein anderes inneres Princip einer Substanz, ihren Zustand zu verändern, als das Begehren und überhaupt keine andere innere Thätigkeit als Denken mit dem, was davon abhängt, Gefühl der Lust oder Unlust und Begierde oder Willen. KANT, I. Metaphysische Anfangsgründe der Naturwissenschaft, AA IV: 544.
} 
Essa definição de vida como "capacidade de uma substância de agir por si” a partir do "desejo" e pelo "pensamento" só pode ser compreendida pela ideia de liberdade, pois não há outra espécie de causalidade na filosofia kantiana. Com isso não se quer dizer que plantas e animais sejam capazes de autonomia moral, mas tão somente que esses organismos não são compreendidos pelo mecanismo e nem mais pela teologia e a única alternativa de causalidade para pensá-los é a liberdade transcendental derivada da $3^{\text {a }}$ antinomia. Ora, trata-se sempre de analogia e a liberdade transcendental é o ponto comum de todas as analogias do organismo.

É nesse mesmo sentido que no fim do $§ 65$, onde Kant examina os tipos de analogia disponíveis para pensar o organismo após uma nova rejeição da analogia mecânica, a saber, a analogia com a arte, o "análogo da vida" e a analogia política, em todas essas três analogias há sobre elas a forma transcendental da liberdade. A analogia com a arte é pensada como uma produção de algo a partir de uma razão exterior ao produto, na forma da liberdade técnica da Crítica do Gosto:

Do ponto de vista do direito, somente se deveria chamar de arte a produção de algo por meio da liberdade, isto é, por meio de um arbítrio que toma a razão por fundamento de suas ações. Pois, ainda que se goste de chamar o produto das abelhas (os favos de cera construídos com regularidade) de obra de arte, isto só acontece por analogia com a arte; assim que se considere, com efeito, que elas não fundam o seu trabalho em uma reflexão racional própria, diz-se que é um produto de sua natureza (do instinto), somente atribuído como arte ao seu criador. ${ }^{53}$

A analogia com a vida é pensada como uma produção na qual a liberdade é imanente ao produto, no sentido exposto acima. E a analogia política é pensada como produção de uma "organização" estatal a partir da comunidade de seres humanos livres:

${ }^{53}$ KANT, I. Crítica da faculdade de julgar, Trad. Fernando Costa Mattos, AA V: 303. 
De uma maneira diversa, pode-se lançar luz sobre uma certa conexão - que, em todo caso também se encontra mais na ideia do que na realidade - através de uma analogia com os referidos fins imediatos da natureza. Assim, no caso da transformação, recentemente empreendida, de um grande povo em um Estado, foi muito e apropriadamente utilizada a palavra "organização" para designar a instituição das magistraturas etc., e mesmo todo o corpo estatal. Pois nesse todo, evidentemente, nenhum membro deve ser um meio, mas sim ao mesmo tempo fim; e, na medida em que colabora para a possibilidade do todo, deve, por seu turno, ser determinado pela ideia do todo no que diz respeito a seu lugar e sua função. ${ }^{54}$

A analogia técnica será criticada, não completamente excluida, mas criticada no sentido kantiano de crítica como exame dos limites. O problema da analogia técnica é que ela introduz uma causalidade livre exterior ao produto. Kant resolverá esse problema com o seu conceito de "fim natural" (Naturzweck) definindo-o como coisa com "causa e efeito de si mesmo": "Eu diria provisoriamente que uma coisa existe como fim da natureza se é causa e efeito por si mesma (ainda que em duplo sentido)"55 Mas Kant não abandona a analogia técnica na medida em que pensa o organismo pela liberdade, elas são fundidas na "técnica espontânea da natureza", isto é, trata-se agora de pensar que o produto é livre porque a técnica livre é imanente a ele e não exterior. Gérard Lebrun interpretou a vida e a espontaneidade do organismo num sentido próximo ao de Hans Jonas. Este interpretou o metabolismo a partir da ideia de liberdade, e Lebrun apontou a liberdade vegetal precisamente na sua capacidade de assimilação e reprodução:

Vida é portanto espontaneidade. Mas, por isso mesmo, a consideração dos organismos vivos ou espontâneos vai chamar a atenção para um caractere comum a todos os corpos orgânicos ('vivos' ou não). As máquinas dotadas de vida ou movidas por representação são evidentemente bem mais do que simples máquinas; a explicação puramente artificialista de seu comportamento evidentemente não é mais satisfatória. Mas ela o seria para certos comportamentos desses

\footnotetext{
${ }^{54}$ KANT, I. Crítica da faculdade de julgar, Trad. de Fernando Costa Mattos, AA V: 375.

${ }^{55}$ KANT, I. Crítica da faculdade de julgar, Trad. Fernando Costa Mattos, AA V: 370-1.
} 
organismos não-vivos que são os vegetais? Por certos aspectos eles também não devem ser classificados entre as máquinas espontâneas? Certamente, esses organismos não têm comando interno e não possuem o mesmo grau de centralização. Mas sua capacidade de assimilação e de reprodução já os coloca infinitamente acima dos 'organismos' no sentido estritamente artificialista. ${ }^{56}$

Como se vê pela interpretação de Gérard Lebrun, a espontaneidade ou liberdade é um complemento à analogia técnica. A assimilação e reprodução são tratadas no $\$ 64$ no exemplo da planta, isto é, a epigênese vegetal pensada como uma técnica interna aos vegetais e livre de causa exterior, Kant exemplifica com as capacidades de regeneração espontânea e o caso do enxerto. O texto kantiano coloca problemas de interpretação muito difíceis, e Lebrun lida com esses problemas de maneira muito cuidadosa, por exemplo, a identificação entre vida e espontaneidade para pensar o reino vegetal sob a ideia de vida, essa inclusão não pode ser realizada apressadamente esquecendo que Kant ainda lidava com um problema de época que era o de limitar o conceito de vida apenas aos animais, excluindo as plantas pois estas não teriam capacidade de movimento espontâneo:

Qual é, para ele, o sentido exato da palavra vivo? Notemos primeiramente este traço essencial: vivo não é e nunca será, para Kant, co-extensivo a organizado. Todo corpo vivo é orgânico, mas nem todo corpo orgânico é vivo, 'pois a vida implica também uma vis locomotiva e não apenas motivos internos' (XXI, 65). Dito de outra maneira, Kant não é Lamarck; ele não pensa ainda em substituir à tripartição 'animal-vegetal-mineral', a bipartição ' $1^{\circ}$ corpos organizados vivos; $2^{\circ}$ corpos brutos e sem vida'; ele sempre se recusará a alargar o conceito de vida, cessando de conservar a 'vis locomotiva' como um de seus traços essenciais. ${ }^{57}$

Lebrun ainda lembrará da tentativa de estender a vis locomotiva às plantas nos Sonhos de um visionário. A reflexão de Kant aí é a de que os animais se

\footnotetext{
${ }^{56}$ LEBRUN, G. Kant e o fim da metafísica, p. 339.

${ }^{57}$ LEBRUN, G. Kant e o fim da metafísica, p. 337.
} 
locomoveriam porque seu estômago estaria sobre a terra e por isso a busca por alimento deveria ser em movimento do animal sobre a terra, enquanto que a planta poderia ser interpretada como estando em movimento sob a terra, pois seu estômago estaria em raizes subterrâneas. No Opus postumum Kant também fará outras tentativas de estender o conceito de vida às plantas, portanto este problema estava em sua consciência, mas a questão nunca foi resolvida por ele.

Ora, a introdução da ideia de espontaneidade e vida não carrega tantos problemas, mas outros comentadores defendem a introdução do conceito de autonomia na equação conceitual do organismo.

Nos opúsculos sobre o conceito de raça, a ideia de vida terá o sentido de sobrevivência como adaptação ao meio. Kant parece estar substituindo a metafísica da scala naturae pela fisiologia da adaptação. Há aqui o argumento de que a diferença dos particulares não é sem finalidade, ela é o produto da epigênese em função da adequação e conservação. A diferença entre as raças e entre os indivíduos tem a epigênese como uma das causas efetivas, ela combina (Zusammenpassung) o sistema ao contexto real da experiência da vida. Vida e adaptação correspondem à liberdade e autonomia do organismo na medida em que a vida é todo esse trabalho de autoconservação, o qual inclui a transformação do sistema em função da adaptação ao contexto, mistura-se aqui a definição prática da vida com a fisiológica.

A posição de Gerard Lebrun está interessada na crítica da teologia e no nascimento da biologia, o comentador francês tem como base o conceito de intenção, que se torna o ponto de virada da Crítica da faculdade de julgar. O conceito de intenção teria sido eliminado da representação da natureza, porque Lebrun entende o conceito de finalidade como finalidade sem fim, mais ou menos idêntica à noção de espontaneidade, a qual ele usa para identificar o conceito de vida e o de organismo 
(“espontaneidade: auto-elaboração, autoconservação",58), como Gerhard Lehmann e Felix Grayeff $(1951)^{59}$. Para Lebrun então a finalidade sem fim é sinônimo de espontaneidade, ou seja, é um meio termo entre a natureza e a liberdade, e ela ultrapassa o conceito tradicional de finalidade com intenção, a qual é um conceito específico da razão. A sua interpretação está correta quando identifica espontaneidade e vida, pois Kant ainda entende vida, com ligeiras variações, como animalidade, a possibilidade de agir por representações por conta da posse de uma alma. Lebrun aponta a origem dessa interpretação em Schelling, mas outra fonte sua foi Gerhard Lehmann:

Que Kant não tivesse como significado de espontaneidade apenas uma de tipo como se, mostra bem a Analítica (\$65) - certamente em primeira linha como descrição compreensiva do 'fenômeno originário' do organismo - na qual se diz que a natureza se auto-organiza, e em verdade não como análogo da arte, pois nesse caso o artista está fora do seu produto. ${ }^{60}$ Grifo nosso.

Gerard Lebrun nos mostra que para superar as ambiguidades entre técnica e mecanismo Kant deu abertura para a ideia de espontaneidade como sinônima de vida. O comentador francês opõe espontaneidade e intenção, a partir daquilo que Kant chama de natureza espontânea e natureza intencional (intentionalis), já a palavra intencionalidade (Intentionalität) aparece apenas no §75. A articulação entre organismo e liberdade é como se nota evidente, ela apareceu pela primeira vez na Primeira Introdução, na fórmula Forma finalis naturae spontanea para a finalidade da natureza, e deve ser contada como parte da conceitualização nos $\S \S 64$ e 65.

\footnotetext{
${ }^{58}$ LEBRUN, G. Kant e o fim da metafísica, p. 345.

59 "entre espontaneidade organizadora (do pensamento) e natureza organizadora" (zwischen organisierender Spontaneität (des Denkens) und organisierter Natur). GRAYEFF, F. Deutung und Darstellung der theoretischen Philosophie Kants, p. 3.

${ }^{60} \mathrm{Da}$ Kant habe keine bloße Als-Ob-Spontaneität im Sinne hat, zeigt wohl die - gewiß in erster Linie als Beschreibung des 'Urphänomens' Organismus aufzufassende - Analytik (§65), in der es heißt, die Natur organisiert sich selbst, und zwar nicht als Analogon zur Kunst, denn da ist der Künstler außerhalb seines Produkt. LEHMANN, G. Beiträge zur Geschichte und Interpretation der Philosophie Kants, p. 241.
} 


\section{CAPÍTULO 3. Finalidade, técnica e sistema}

\subsection{Introdução no sistema das faculdades pelos conceitos de finalidade, técnica e sistema}

O trio de conceitos 'finalidade, técnica e sistema' aparece pela primeira vez na primeira Introdução à Crítica da faculdade de julgar, e isso apesar de o conceito de técnica já ter aparecido na refutação da prova físico-teológica, e finalidade e sistema no Apêndice à dialética transcendental. Mas os três conceitos articulados e deduzidos simultaneamente é um feito das Introduções à terceira Crítica. O organismo é pensado a partir daqui como articulação entre técnica e sistema, na medida em que aqui a finalidade da técnica é o sistema. Ao final desse capítulo será mostrado que o conceito de sistema será responsável por possibilitar o pensamento da produção da finalidade interna, mas também o do parentesco entre os organismos. Todavia, a posição das Introduções é a de que o sistema não é causa, mas efeito, pois se trata da autonomia da faculdade de julgar na operação de reflexão e comparação de formas particulares para reuní-las segundo a finalidade em vista de um sistema. Como nós veremos no capítulo 4 e temos visto nos capítulos anteriores, a representação do organismo pela faculdade de julgar toma uma ordem inversa a da razão e exige a introdução de outros conceitos como o da finalidade segundo a espontaneidade, a técnica e a comunidade.

A terceira Crítica possui algo peculiar em relação a estrutura formal das outras duas críticas, ela possui três deduções: uma na Introdução para a finalidade em geral, outra para o juízo estético e uma terceira para o juízo teleológico. A dedução só é enunciada com clareza na Introdução publicada, mas não na primeira, a nossa opinião é que a ideia de introdução enciclopédica é a ideia estruturante e justificadora dos conceitos na primeira Introdução, e nela se pode notar pelo menos o aspecto 
jurídico da dedução transcendental. A nossa passagem pelas Introduções tem por objetivo introduzir o trio de conceitos 'finalidade, técnica e sistema', mas isso não é possível sem lidar com os elementos estruturantes do texto kantiano, por isso insistimos no tema da dedução e da introdução enciclopédica. Para a lógica do organismo, a causalidade pela ideia de sistema produz finalidade interna pela divisão de um fim em uma multiplicidade de fins internos, e possibilita a fórmula "tudo é meio e fim", é dessa maneira que a finalidade interna é introduzida no Apêndice à dialética transcendental a partir da inteligência divina, ao mundo teleológico, e a finalidade interna de cada organismo. A nossa leitura da primeira Introdução procura apresentar primeiramente os conceitos de finalidade, técnica e sistema em pé de igualdade, e, ao fim do capítulo, a finalidade interna é subordinada ao conceito de sistema segundo o processo de reprodução pela doutrina embriológica da préformação. Comecemos pela primeira Introdução.

Kant afirma que há apenas dois tipos de introdução: a introdução a uma teoria, e a introdução de uma teoria ou ciência num sistema de teorias ou de ciências, por exemplo, a introdução de um tratado de química a esta ciência e a introdução da química no sistema de todas as ciências da natureza: "Toda introdução de uma exposição é a introdução em uma teoria pré dada ou a introdução da teoria mesma em um sistema"61 A introdução em uma teoria é a introdução propedêutica, que é possivelmente o tipo de introdução da primeira e da segunda Críticas, e possivelmente da maior parte das obras de Kant que possuem uma introdução. A introdução de uma teoria num sistema de teorias é a introdução enciclopédica, que é a da terceira Crítica, a qual serviria "para indicar o lugar no conjunto de todas as

\footnotetext{
${ }^{61}$ Alle Einleitung eines Vortrages ist entweder die in eine vorhabende Lehre, oder der Lehre selbst in ein System. KANT, I. Erste Einleitung, AA XX: 241.
} 
teorias" ${ }^{\prime 62}$ Ou seja, esse tipo de introdução introduz uma ciência num sistema de ciencias para indicar o seu lugar no sistema, além disso tem também a função de indicar os limites de cada ciência, na medida em que compara essa nova ciência com as outras que estão no sistema.

Para a possibilidade de uma introdução enciclopédica é necessário que seja dado de antemão ao menos a ideia do sistema e as fontes de conhecimento que fundamentam essa ideia do sistema, ou seja, a nova teoria ou nova ciência terá de ser pensada no sistema e na crítica da razão. A introdução enciclopédica da faculdade de julgar vai ser feita então por um lado no sistema da filosofia (natureza e liberdade) e por outro lado no sistema da crítica (entendimento e razão): "A introdução da faculdade de julgar no sistema das faculdades puras de conhecimento por conceitos assenta inteiramente no seu princípio transcendental", que é o princípio da finalidade e da técnica da natureza e natureza como sistema. Esse princípio transcendental é aquilo que fundamenta a introdução da faculdade de julgar no sistema das faculdades superiores, ou seja, a faculdade entra no sistema porque agora ela possui um princípio de legislação, assim como as outras duas faculdades do sistema. Esse princípio que aqui está sendo pensado pelo conceito de introdução enciclopedica, na Introdução publicada, de 1790, vai ser pensado por uma dedução.

Kant começa a introdução enciclopédica pelo problema da introdução do conceito de técnica na filosofia como uma parte autônoma. Kant define sistema e crítica como duas atividades diferentes. Por sistema da filosofia deve-se entender a totalidade do conhecimento racional, e por crítica a investigação sobre a possibilidade do sistema da filosofia, na medida em que se testa e se esboça esse

\footnotetext{
${ }^{62}$ um ihr die Stelle in dem Inbegriffe der Lehren, mit welchen sie durch gemeinschaftliche Principien zusammenhängt, nach Grundsätzen anzuweisen. KANT, I. Erste Einleitung, AA XX: 241.
} 
sistema. A divisão do sistema tem que ser feita do ponto de vista formal e material: a parte apenas formal do sistema da filosofia se chama lógica, é formal porque se ocupa apenas com a forma do pensamento. A parte material que se ocupa com objetos pensados pela razão é o sistema real da filosofia, o qual se divide segundo a diferença de objetos em filosofia teórica e filosofia prática, ou filosofia da natureza e filosofia dos costumes. Após a divisão do sistema da filosofia em duas partes, Kant introduz o conceito de técnica como não fundando uma terceira parte autônoma do sistema da filosofia, mas como consequências das duas partes. Para Kant, há uma aparência de filosofia prática em algumas ciências teóricas, porque estas possuem proposições práticas. O seu posicionamento será o de estabelecer que essas proposições são práticas quanto a forma, mas não quanto ao conteúdo. Daí que a geometria possua proposições práticas quanto a forma, e também a física possua proposições práticas quanto a forma, assim como a dietética, a economia de estado, a prudência de estado, mas nenhuma delas possuem proposições práticas quanto ao conteúdo, ou seja, o conteúdo dessas proposições deveria ser a liberdade para que devessem ser consideradas como ciências práticas autônomas. Como isso não ocorre, essas ciências então pertencem a filosofia da natureza, mesmo possuindo proposições práticas, Kant então propõe que se mude o nome para proposiçoes técnicas, para corrigir o sentido das proposições práticas, e introduz a partir daqui a discussão sobre a técnica: "Todas as demais proposições de execução, qualquer que seja a ciência a que se ligam, podem, caso haja preocupação com a ambiguidade, ser chamadas de técnicas em vez de práticas." ${ }^{, 63}$ Portanto, para Kant, a técnica não vai ser um membro da divisão do sistema, a técnica será introduzida no sistema. Essa divisão originária do sistema é derivada da terceira antinomia. Até aqui trata-se somente das partes que

${ }^{63}$ KANT, I. Erste Einleitung, AA XX: 200. 
derivam necessariamente da divisão e constituem os membros necessários do sistema. E como é um sistema então é preciso que haja articulação entre as partes ou membros do sistema.

A verdadeira introdução e legitimação do conceito de técnica da natureza ocorrerá pelo sistema das faculdades superiores de conhecimento e não pelo caminho do sistema da filosofia. $\mathrm{O}$ argumento de Kant aqui é o de que se o entendimento legisla a natureza e a razão legisla a liberdade, então, se a faculdade de julgar tem que pertencer ao sistema das faculdades superiores de conhecimento, e estas faculdades são superiores porque legislam, então a faculdade de julgar também deve provar-se como legisladora. A elevação da faculdade de julgar ao estatuto de faculdade legislante assenta no seu parentesco com as outras duas, tal parentesco é a discursividade. Além disso, essa legislação não será sobre a natureza e nem sobre a liberdade, mas sobre a natureza como arte. Para chegar até aí, Kant antes apresenta a divisão tripartite das faculdades superiores: o entendimento, a razão e a faculdade de julgar. A divisão do sistema das faculdades é uma tricotomia, o que significa que deverá haver três críticas para que se acabe o sistema. Isso aparece um pouco mais a frente:

Agora, se o entendimento fornece a priori leis da natureza, ao passo que a razão fornece leis da liberdade, é de esperar-se, por analogia, que a faculdade de julgar, que proporciona a ambas as faculdades a sua interconexão, também forneça, do mesmo como aquelas, os seus próprios princípios a priori e, talvez, estabeleça o fundamento para uma parte especial da filosofia - ainda que esta somente possa, como sistema, possuir duas partes. ${ }^{64}$ Grifo nosso.

O sistema da filosofia tem duas partes, o sistema das faculdades superiores tem três partes, então falta uma terceira Crítica. O argumento de Kant é então sistemático, ou

${ }^{64}$ KANT, I. Crítica da faculdade de julgar, Trad. Fernando Costa Mattos, AA V: 202. 
seja, está faltando algo no sistema. O objetivo é a investigação de um princípio $a$ priori da faculdade de julgar, cuja justificação é o pertencimento à família das faculdades superiores, as quais possuem princípios desse tipo. Kant além disso afirma no final dessa citação que será investigado se esse princípio fundamenta uma parte especial da filosofia, mesma que ela possua apenas duas. Ou seja, está em jogo uma terceira parte do sistema, mas essa terceira parte não terá uma doutrina, portanto não haverá uma doutrina da arte e nem uma doutrina da vida.

Da primeira condição, o pertencimento ao sistema das faculdades surge a ideia de legislação, isto é, a de que a faculdade deve ser legisladora. De uma segunda condição surge a ideia de finalidade. A faculdade de julgar tem de aplicar conceitos, mas não é uma faculdade produtora de conceitos, tem de haver um conceito próprio a ela, mas ela nao é uma faculdade produtora de conceitos. É nesse sentido que a faculdade de julgar tem uma finalidade sem fim, ela precisa aplicar conceitos, mas na operação de relfexão ela não possui conceitos. Ora, se ela não tem conceitos, ela tem um procedimento sobre os conceitos, que é a subsunção.

Mas a faculdade de julgar é uma faculdade de conhecimento tão peculiar, e em nada autossuficiente, que ela não fornece nem conceitos, como o entendimento, nem ideias como a razão, visto ser uma faculdade que meramente subsume sob conceitos dados de outra procedência. ${ }^{65}$

Trata-se assim de uma faculdade que não produz conceitos e nem ideias, ela apenas subsume, então o princípio será um que a natureza seja submetida apenas à subsunção sem conceitos ou ideias.

Caso deva haver, pois, um conceito ou regra proveniente originariamente da faculdade de julgar, e, portanto, ele teria de ser um conceito de coisas da natureza na medida em que esta se orienta pela nossa faculdade de julgar, e portanto de uma natureza constituida de tal modo que nao se pode ter

${ }^{65}$ KANT, I. Crítica da faculdade de julgar, Trad. Fernando Costa Mattos, AA V: 202. 
qualquer conceito dela a nao ser enquanto seu arranjo se oriente por nossa faculdade de subsumir leis particulares dadas sob leis mais gerais. ${ }^{66}$

Portanto, será do procedimento de subsunção de leis particulares sob leis mais gerais que se perceberá a finalidade interna à faculdade de juízo relfexionante. E como dito antes sobre a introdução enciclopédica, o sistema das faculdades possui duas faculdades que legislam, por isso a terceira faculdade deverá legislar. Kant está buscando o princípio próprio da faculdade de julgar na atividade de subsunção das leis particulares sob leis mais gerais. A natureza tem que ter a forma da mera subsunção, que é pensada aqui como subsunção de leis particulares subsumidas sob leis mais gerais que não são dadas.

O juízo reflexionante como juízo sem conceito introduz a sua propriedade essencial sobre a representação, a de que ele tem um fim que não é determinado, daí a passagem ao conceito de finalidade da natureza. E na medida em que deve poder fazer esse conceito segundo uma finalidade então ele terá a aparência da técnica, a qual Kant chamará de procedimento técnico da faculdade de julgar. E por fim o ideal de conhecimento que ele deve perseguir sem nunca determina é o ideal do sistema da natureza.

Ainda no procedimento de introdução no sistema das faculdades superiores, Kant afirmar que se o determinar necessita de princípios, do mesmo modo o refletir necessitará de algum princípio. Kant distingue o refletir e o determinar em função da busca pelo princípio da reflexão. O determinar é subsunção do conceito dado como fundamento que se aplica a uma representação empírica. O refletir é comparar e reunir representações com outras representações ou com a sua faculdade de conhecimento. No geral então o refletir é comparar, e o ato de comparação terá a

${ }^{66}$ KANT, I. Crítica da faculdade de julgar, Trad. Fernando Costa Mattos, AA V: 202. 
posse justificada de um princípio transcendental sem o qual a experiência pela comparação não poderia sair do labirinto do múltiplo, isto é, a infinidade de formas empíricas.

O princípio do determinar, na verdade, os princípios, estão dados nos conceitos e esquemas que fundamentam a representação geral dos objetos. Portanto, se conceitos guiam a determinação, outros conceitos devem guiar a reflexão, daí a ideia de que se deve poder encontrar conceitos empíricos, em sua formulação mais básico o princípio da reflexão sobre a natureza é: "que para todas as coisas naturais se podem encontrar conceitos determinados empiricamente". Vê-se que ainda não se fala em sistema, mas apenas em conceito, pois se trata ainda do mínimo da indução, isto é, as comparações entre as formas particulares tem como finalidade a descoberta de conceitos comuns a elas, e o conceito de sistema será o ideal máximo de todas essas comparações.

Esse território livre das operações do entendimento se dá onde a intuição empírica é dada, mas não há conceito particular para ela, o conceito precisa ser descoberto. Nesse caso a reflexão precisa de um princípio transcendental que não apenas o esquematismo, porque estes se limitam ao uso das categorias. As categorias estão presentes em todas as representações empíricas, todo particular é pensado pela categoria de substância, mas as formas particulares que distinguem as substâncias entre si não são legisladas pelas categorias. As diferenças entre a substância Leopardus pardalis e a substância Leopardus pajeros devem ser descobertas empiricamente pela reflexão que é nesse caso o grau mais simples de indução. Aqui então não se trata das categorias, mas de conceitos empíricos não dados, é essa espécie de construção empírica do conceito que Kant chamará de procedimento técnico guiado por uma finalidade que é a descoberda do conceito. Esse conceito que 
precisa ser descoberto não pode ser baseado em outra lei empírica conhecida anteriormente, porque a reflexão se limitaria a uma mera comparação de formas empíricas, ela precisa comparar, mas tem de se elevar da comparação a conceitos e leis mais gerais, por isso precisa de um princípio transcendental para sair desse círculo vicioso da comparação. A comparação por si não daria conta de chegar ao sistema da natureza, porque ela mesma, ao cabo, pressupõe esse sistema:

que a natureza - também em vista de suas leis empíricas - tem observado uma certa economia adequada a nossa faculdade de julgar e uma uniformidade apreensível, e que essa pressuposição deve preceder toda comparação como princípio da faculdade de julgar a priori $^{67}$

O procedimento de subsunção sem conceito, que por sua vez se reduz a comparação em funçao de conceitualização, é a origem do princípio de finalidade da natureza, a sua dedução metafísica: "E aqui se origina o conceito de uma finalidade da natureza como um conceito que é próprio da faculdade de julgar reflexionante, e não da razão"68 A definição empregue em toda a obra de conformidade a fins ou finalidade é a daquilo cuja existência pressupõe uma representação: "denominamos conforme a fins aquilo cuja existência parece pressupor uma representação dessa mesma coisa"69. A existência da coisa pressupõe a representação dela, ou seja, a ideia de que um conceito é a causa da coisa, esse conceito é o seu fim. É a mesma definição dada no terceiro momento da Analítica do belo: "Se se quer definir o que é um fim segundo suas determinações transcendentais (...) então fim é o objeto de um conceito quando este é considerado a causa daquele" ${ }^{, 70}$ A diferença entre finalidade e fim, é que a finalidade tem uma aparência de teleologia ou ainda uma orientação por

\footnotetext{
${ }^{67}$ KANT, I. Erste Einleitung, AA XX: 213.

${ }^{68}$ KANT, I. Erste Einleitung, AA XX: 216.

${ }^{69}$ KANT, I. Erste Einleitung, AA XX: 216.

${ }^{70}$ KANT, I. Erste Einleitung, AA XX: 220.
} 
esta. O juizo reflexionante vai reunindo os particulares em direção ao sistema da natureza, e a natureza terá a aparência de ter um fim:

mas as leis da natureza, que são constituidas e referidas umas às outras como se a faculdade de julgar as tivesse projetado em função de sua propria necessidade, têm semelhança com a possibilidade das coisas que pressupõe uma representação dessas coisas como fundamento das mesmas. ${ }^{71}$ (Grifo nosso).

A faculdade de julgar então projeta (entworfen) uma unidade na natureza como se a natureza fosse produzida uma causa conceitual, isto é, como se a natureza tivesse um projeto, um fim supremo. Ao cabo, a faculdade de julgar fica aparentada à razão, e isso também parece estar dentro da tese de Kant de que ela é faculdade intermediária no parentesco ou afinidade entre a familia das faculdades superiores. Está finalidade elaborada pela introdução enciclopédica é meramente formal, pois as formas, apenas do ponto de vista da relação entre elas, são pensadas como finalizadas, ou seja, não é um objeto que é teleológico, mas a relação entre os objetos é que é pensada como se fosse conformes a fins: “Com isso, porém, essas formas mesmas não são pensadas como conforme a fins, mas apenas a relação delas entre si”

Essa comparação das formas das coisas particulares e função de conceitos comuns que introduz finalidade sem fim na representação reune estas mesmas formas particulares segundo uma unidade técnica segundo o procedimento técnico da faculdade de julgar reflexionante. Kant então introduz o terceiro nome desse mesmo princípio, "natureza como arte" ou "técnica da natureza".

Kant dá alguns esclarecimentos sobre o estatuto cognitivo do princípio: 1. ele não funda nenhuma teoria pois não contém conhecimento de objetos e suas propriedades ou seja não constitui os objetos, assim como a lógica; mas 2.

${ }^{71}$ KANT, I. Erste Einleitung, AA XX: 219. 
proporciona um princípio para a pesquisa da natureza (há uma oposição entre teoria e pesquisa); 3. não é lei objetiva, mas máxima para observar metodicamente e reunir as formas da natureza em um sistema regulativo da natureza; e 4. o sistema da filosofia não ganha parte nova, mas a filosofia teórica é ampliada pela crítica tão-somente, já que o princípio pertence apenas ao sistema da crítica das faculdades de conhecimento e não ao sistema da filosofia; e por fim é um princípio heurístico para a descoberta das conexões dentro do sistema pressuposto hipoteticamente. O estatuto regulativo é repetido a todo momento pois se tomamos a técnica como conceito determinante seremos obrigados a introduzir deus como causa dessa finalidade da natureza.

Na primeira apresentação da ideia de experiência como sistema é dada grande enfase ao conceito de experiência. Kant afirma que embora a experiência também constitua um sistema segundo leis transcendentais, ela também deve constituir um sistema segundo leis empíricas. O argumento aqui é o de uma sobra na experiência justificável pela limitação do nosso entendimento discursivo. Aqui aparece apenas a ideia de que o entendimento possui limitações e que as leis particulares sobram para que outra faculdade legisle sobre elas. Uma coisa que precisa ser esclarecida aqui é que Kant afirma que a natureza ou a experiência é sistema pelo entendimento, na verdade daqui não sai o conceito da "natureza como sistema", que é o conceito da faculdade de julgar, mas o da natureza pensada por um sistema de conceitos, as categorias constituem um sistema:

tal conceito é o conceito de uma experiencia como sistema segundo leis empíricas. Pois, embora esta constitua um sistema segundo leis transcendentais que contêm a condição de possibilidade da experiência em geral, é possível uma tão infinita diversidade de leis empíricas, e uma tão grande heterogeneidade de formas da natureza que pertenceriam à experiencia particular, que o conceito de um 
sistema segundo tais leis (empíricas) tem de ser inteiramente estranho ao entendimento ${ }^{72}$

A experiência como sistema para a faculdade de julgar é possivel porque as leis empíricas não pertencem ao entendimento, há aí uma lacuna de legislação que será um campo para a faculdade de julgar. A ideia de sistema é necessária para que as leis particulares se conectem em leis progressivamente mais gerais, a faculdade de julgar terá de produzir tais leis mais gerais a partir de leis particulares.

O fundamento para que deva haver sistema nesse dois sentidos é a "unidade da natureza", essa unidade é exigência da razão: "Pois isso é requerido pela unidade da natureza segundo um princípio da ligação completa de tudo aquilo que está contido nesse conjunto de todos os fenômenos." "73 É a razão que exige essa "ligação completa", pois o entendimento realiza a parte do sistema segundo leis transcedentais aplicadas ao conceito de matéria, e sobra a parte das formas particulares para a faculdade de julgar para que a natureza enquanto sistema progrida o máximo possível. Como justificação do princípio da experiência como sistema está o problema do labirinto do múltiplo, segundo o qual as faculdades de conhecimentos perder-se-iam no infinito de formas particulares e e leis particulares, é necessário então que haja um fio condutor para sair do labirinto.

Na Crítica da razão pura havia uma teoria da constituição dos objetos através de categorias e formas puras. Menos presa a uma teoria da constituição dos objetos pela representação, a Crítica da faculdade de julgar, sobretudo as Introduções, desenvolvem uma metodologia para sair do labirinto do particular pelo método do fio condutor para se orientar na infinitude de formas naturais. A questão é que para Kant

\footnotetext{
${ }^{72}$ KANT, I. Erste Einleitung, AA XX: 203.

${ }^{73}$ KANT, I. Erste Einleitung, AA XX: 203.
} 
a mesma metodologia, não chamamos isso de lógica transcendental, ou lógica do irracional, a mesma metodologia para a superação do labirinto do particular pelo fio condutor da sistematização empírica, portanto uma filosofia da pesquisa antes que da construção da natureza, dá a esta a forma técnica.

Na origem da ideia de fio condutor está a "filosofia da pesquisa" de Francis Bacon, uma referência pouco reconhecida para a terceira Crítica. Mas é Bacon ainda o filósofo da interpretação da natureza. A maior parte dos estudiosos reconhece na terceira Crítica uma transfiguração da monadologia leibniziana ${ }^{74}$, ou ainda da natura naturans espinozana, da alma do mundo platônica, uma crítica do hilozoísmo e da teleologia etc, mas pouco se fala sobre o tratamento dado ao empirismo pela lógica da reflexão empirista e a ideia de sistema que remonta à diairesis platônica. Uma das primeiras, senão a primeira obra de Francis Bacon levou o nome de Fio do labirinto ou fórmula da pesquisa (Filum Labyrinthi, sive Formula Inquisitionis, em inglês 'Thread of the Labyrinth, or Formula of Enquiry') (1606). É a partir dessas referências que Kant desenvolve a sua teoria da aparência técnica do juízo reflexionante pelo método de orientação da pesquisa pelo fio condutor que vai do múltiplo ao sistema. Para que o infinito de leis empíricas possam ser subsumidas a leis gerais, ou que o agregado de leis se torne sistema de leis é necessária a pressuposição do princípio transcendental da faculdade de julgar a natureza como sistema de leis empíricas. No parágrafo seguinte Kant explica porque é o principio da faculdade de julgar: “em sua legislação transcendental da natureza [o entendimento] abstrai de toda diversidade de leis empíricas possiveis; ele só leva em consideração, naquela, as condições de possibilidade de uma experiência em geral." ${ }^{75} \mathrm{O}$

74 MODEL, A. Metaphysik und reflektierende Urteilskraft bei Kant: Untersuchungen zur Transformierung des leibnizschen Monadenbegriffs in der 'Kritik der Urteilskraft'. Athenäum (1987)

${ }^{75}$ KANT, I. Erste Einleitung, AA XX: 210 
entendimento então deixa de lado o particular e só produz o universal, as leis e conceitos universais:

Somente a faculdade de julgar, que é obrigada a colocar as leis particulares sob leis superiores (ainda que sempre empíricas) também segundo aquilo que elas têm de diferente sob as mesmas leis naturais universais, precisa ter tal princípio como fundamento de seu procedimento. $^{76}$

A faculdade de julgar tem de acabar algo que o entendimento não é capaz de fazer, mas que é de algum modo continuação dele, a natureza como sistema. Essa tarefa é realizada com um princípio próprio, o qual tem apenas a forma de uma pressuposição de haver um sistema, de se erguer do particular ao universal.

A definição de natureza enquanto sistema é a mesma do Apêndice à dialética transcendental como sistema lógico pela divisão do conceito. A forma lógica de um sistema consiste na divisão de um conceito universal de tal modo que o particular é visto como contido sob o universal pela divisão deste em particulares. A subsunção no juízo determinante funciona à revelia desse procedimento, são conceitos universais que independem de classificação e especificação; a categoria de substância, por exemplo, vale para todos os objetos do sentido externo sem exceção. O sistema é o lado da divisão, técnica é o lado da montagem do quebra cabeças que foi dividido. Sistema é a divisão do universal em particulares, e esse processo Kant chama de especificação. A direção oposta, do particular ao universal, é a classificação: nós comparamos dois particulares e classificamos sob um conceito comum. A ideia aqui é a de que a faculdade de julgar quando vai classificar o particular na sua infinita diversidade, necessariamente pressupõe que a natureza se divide, se especifica a partir de um conceito universal formando um sistema. A

${ }^{76}$ KANT, I. Erste Einleitung, AA XX: 210. 
classificação empírica pressupõe a especificação a priori. Há aqui essa espécie de complementaridade entre juízo e razão, entre técnica da natureza e natureza enquanto sistema, e finalidade da natureza é essa adequação entre técnica e sistema, na medida em que o particular pressupõe a subsunção ao sistema, sistema é o fim do particular. Kant integra os princípios em uma formulação: “a natureza específica suas leis universais em leis empíricas conforme a forma de um sistema lógico em função da

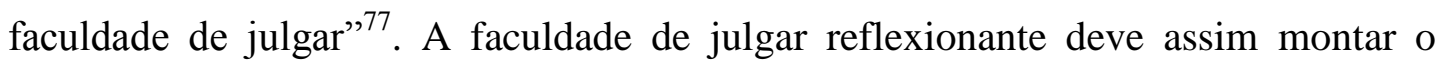
arranjo dos particulares através de comparação entre eles, mas a comparação não é suficiente e ela precisa pressupor um sistema. Como se vê, o característico da primeira Introdução é a articulação de conceitos que antes estavam sendo tomados de modo desarticulados, como é o caso de técnica e sistema na primeira Crítica, não que devessem estar, mas que a compreensão conceitual do organismo necessite desta articulação que a Introdução proporciona.

${ }^{77}$ KANT, I. Erste Einleitung, AA XX: 215. 


\subsection{Dedução da finalidade transcendental}

A primeira Introdução se divide entre o problema da passagem e o da introdução da faculdade de julgar no sistema da filosofia e das faculdades superiores de conhecimento, isto é, entre as faculdades legisladoras. O problema da legislaçao é o motivo de a segunda Introdução pensar uma dedução transcendental, ou seja, uma justificação da legislação da faculdade de julgar no princípio transcendental da finalidade. $O$ conceito de passagem tem essa função de conceito geral que a finalidade geral também tem como gênero das espécies finalidade estética e finalidade orgânica. É por isso que o tema da passagem está interligado ao da dedução do princípio. Colocando de lado o problema da passagem, o qual também é fundamental para pensar o organismo, a dedução da finalidade na Introdução se deve, segundo nossa opinião, à necessidade de as duas partes da Crítica em questão terem um tronco comum. Pela segunda Introdução, esse tronco comum é o conceito de "finalidade transcendental" e pela primeira Introdução eram os três conceitos simultaneamente articulados: finalidade, técnica e sistema.

O motivo da anterioridade da finalidade formal na primeira Introdução, e na segunda Introdução, que Kant também chama de finalidade transcendental, é devido ao fator sistemático, isto é, existem duas espécies distintas de finalidade que devem poder ser derivadas de uma única finalidade mais geral que as inferiores. Daí que as Introduções tenham como tarefa a introdução e dedução dessa finalidade universal. Tanto a introdução enciclopédica quanto a dedução transcendental tratam de justificar uma legislação, trata-se da legalidade do contingente que tratamos no primeiro capítulo. A primeira Introdução usou o procedimento da introdução enciclopédica, o que tornou a justificação deveras extensa, isso deve explicar o tamanho reduzido da segunda Introdução. Kant aqui descobre que só é preciso 
deduzir a finalidade geral, pois as duas espécies inferiores são o verdadeiro assunto da terceira Crítica $^{78}$ A simplicidade dessa Introdução é então devida a troca da introdução enciclopédica pela dedução transcendental. Kant começa pelo estabelecimento do sistema da filosofia em duas partes: filosofia teórica e filosofia prática, e passa ao acerto sobre o conceito de técnica. A segunda seção pensa o sistema pelo conceito de domínio, território e campo. Aqui já se trata do problema da dedução transcendental. A faculdade de julgar não possui domínio como entendimento e razão sobre natureza e liberdade, ela possui apenas um território onde ela não é legislante no sentido forte do termo, mas é legal. O princípio da finalidade não legisla determinantemente sobre um domínio, mas produz uma infinidade de leis particulares dentro de um território, o território das formas particulares encadeadas entre si.

A finalidade é a legislação das formas particulares pela autonomia da faculdade de julgar reflexionante. Como vimos, há teleologia regulativa pela sistematização da razão sobre o entendimento ou pela auto-produção do juízo reflexionante, e o princípio da finalidade formal ou transcendental é do segundo tipo. Kant começa a dedução transcendental alertando que não haverá teoria de objetos fundados no princípio da finalidade formal, mesmo que o princípio seja a priori e transcendental. A filosofia kantiana dos princípios de conhecimento se divide primeiramente em princípios a priori e princípios empíricos, e os princípios a priori se subdividem em princípios transcendentais e princípios metafísicos. Os princpios transcendentais são aqueles que possibilitam a experiência sem todavia ter qualquer coisa dela; os princípios metafísicos possibilitam a experiência tendo sido

${ }^{78}$ Cf. PETER, J. Das transzendentale Prinzip der Urteilskraft: eine Untersuchung zur Funktion und Struktur der reflektierenden Urteilskraft bei Kant, p. 83 
formulados a partir de um mínimo empírico. O princípio da finalidade é um princípio transcendental que possibilita a experiência, segundo Kant, o reconhecimento de que ele possibilita a experiência está nas máximas da sabedoria metafísica (Sentenzen der metaphysischen Weisheit) que expressam a atividade final da faculdade de julgar como o seu fato. O princípio, além disso, não pode ser deduzido da experiência porque esta não fornece a necessidade lógica expressa no princípio; e nem ter uma dedução psicológica, pois a finalidade só é possível pela introdução de um "dever ser" nas faculdades de conhecimento. Logo, ele carece de uma dedução transcendental (bedarf also auch einer transzendentalen Deduktion). ${ }^{79}$

A dedução transcendental do princípio da finalidade formal ou transncendetal será feito pela determinação da autonomia do entendimento e instituição da autonomia da faculdade de julgar, isto é, a limitação da autonomia do entendimento legitima a autonomia da faculdade de julgar, os limites legislativos de uma faculdade dão permissão para outra legislação. Precisamos então compreender a limitação da legislação do entendimento para então fazer a passagem para a legislação da faculdade de julgar. Da ideia de que o princípio é transcendental porque é a priori e possibilita a experiência Kant passa ao conceito de uma experiência necessária na medida em que fundada em leis em que a natureza é necessária. Para a outra legislação, Kant está certamente pensando que da experiência possível não se passa à necessidade mas à contingência:

Nós encontramos, nomeadamente, nos fundamentos da possibilidade de uma experiência primeiramente em verdade algo necessário, isto é, as leis universais sem as quais a natureza em geral (como objeto dos sentidos) não pode ser pensada, e essas assentam nas categorias aplicadas às condições formais de todas nossas intuições posssíveis, na medida em que elas são dadas a priori. ${ }^{80}$

\footnotetext{
${ }^{79}$ KANT, I. Kritik der Urteilskraft, AA V: 182.

${ }^{80}$ KANT, I. Kritik der Urteilskraft, AA V: 183.
} 
O entendimento tem autonomia e legisla sobre o conceito de "natureza em geral" (Natur überhaupt) como natureza necessária segundo o recorte da intuição a priori. Mas o conhecimento empírico introduzirá uma infinidade de elementos não antecipáveis pelo apriorismo do entendimento.

Ora, os objetos do conhecimento empírico, fora daquelas condições formais do tempo, são ainda determinados de muitos modos, ou, tanto quanto podemos julgar, determináveis de muitos modos ${ }^{81}$

A primeira abertura para a legislação da faculdade de julgar é assim o conhecimento empírico no reconhecimento de uma determinabilidade infinita do empírico, essa infinitude de determinações é possível numa outra concepção de natureza. Kant limita a concepção de natureza como "natureza em geral" ao entendimento, e a natureza legislada pela faculdade de julgar será aqui as naturezas especificamente-diversas (spezifisch-verschiedene Naturen, außerdem, was sie, als zur Natur überhaupt gehörig). Há aí então a ideia de uma natureza infinitamente diversificada fruto de causas igualmente infinitas que produzem as especificações da "natureza em geral” (Natur überhapt). Esse território não legislado pelo entendimento, no reconhecimento da especificação da natureza em geral, constituirá a legislação da faculdade de julgar nas leis empíricas ou leis particulares. Como o entendimento legisla segundo a necessidade e a legislação alternativa escapa ao entendimento, haverá então uma passagem para a legislação da contingência:

Portanto, deve-se pensar uma possibilidade de leis empíricas infinitamente múltiplas na natureza, as quais para a nossa inspeção são ainda contingentes (não podem ser conhecidas a priori); e em vista das quais se julga a unidade da natureza segundo leis empíricas, e a

${ }^{81}$ KANT, I. Kritik der Urteilskraft, AA V: 183. 
possibilidade da unidade da experiência (como sistema segundo leis empíricas) como contingente. ${ }^{82}$

Como se vê, conceitualmente Kant divide a natureza em duas, em geral e específica, necessária e contingente, e afirma que deve haver uma legislação contingente na outra parte conceitual e a faculdade de julgar deve tomar como seu território essa legislação contingente:

assim, a faculdade de julgar deve admitir como princípio a priori para seu próprio uso que existe para a inspeção humana o contingente nas leis naturais particulares empíricas e ainda uma unidade legal todavia não fundante mas pensável na ligação do seu multiplo em uma experiência possivel em si. ${ }^{83}$

Ora, a contingência nas leis empíricas e a necessidade no entendimento só podem ser conectadas se a faculdade de julgar toma a natureza em geral do entendimento como fim da sua reflexão rumo a subsunção. A faculdade de julgar procede originária então por uma finalidade não determinada mas refletida:

Consequentemente, dado que a unidade legal em um ligação, que conforme uma intenção necessária (uma carência) do entendimento, reconhecemos como ao mesmo tempo contingente em si, é representada como finalidade do objeto (aqui da natureza), então a faculdade de julgar, que é somente reflexionante em vista das coisas sob leis empíricas possíveis (a serem descobertas) deve pensar a natureza segundo um princípio da finalidade para as nossas capacidades de conhecimento, princípio que se expressa nas supracitadas máximas da faculdade de julgar. ${ }^{84}$

Kant termina a dedução limitando a autonomia da faculdade de julgar a uma heautonomia, uma legislação para si, e apresentando a sua lei, a lei da especificação da natureza. A faculdade de julgar reflexionante tem seu domínio, ou antes, seu território na natureza em espécie e não no geral. É a forma que dá a particularidade e

\footnotetext{
${ }^{82}$ KANT, I. Kritik der Urteilskraft, AA V: 183.

${ }^{83}$ KANT, I. Kritik der Urteilskraft, AA V: 183-4.

${ }^{84}$ KANT, I. Kritik der Urteilskraft, AA V: 184.
} 
espeficidade das coisas, a matéria é tomada aqui como o gênero informe e é legislado pelo entendimento. As formas particulares dão oportunidade para a heautonomia na "lei da especificação da natureza" (Gesetz der Spezifikation der Natur):

A faculdade de julgar tem assim também um princípio a priori para a possibilidade da natureza, mas apenas em sentido subjetivo, pelo qual prescreve uma lei não à natureza (como autonomia), mas a ela mesma (como heautonomia) para a reflexão sobre aquela, a qual pode-se nomear lei da especificação da natureza em vista das suas leis empíricas. ${ }^{85}$

A dedução assim foi feita em três partes: a prova de que o princípio é transcendental, a prova de que é necessário, a prova de que é lei. A primeira prova consistiu em distinguí-lo de princípios empíricos e metafisicos. Kant aí recusa outros tipos de dedução, ou seja, de justificação cética, dogmática, psicológica ou empírica etc, não dariam conta da questão. Na segunda prova, Kant alegou que a justeza e necessidade da dedução deve assentar na limitação do entendimento, na medida em que este produz leis universais que possibilitam os objetos da experiência e ainda precisa (bedarf) de algo mais, a possibilidade de solucionar esse grande problema (die Größe der Aufgabe) do entendimento justifica a aceitação do princípio: a ordenação das leis particulares que ele só pode conhecer contingentenmente, essas leis particulares possibilitam o progresso da experiência possível para as experiências particulares. A fundamentação da possibilidade da experiência pela necessidade deve ser completada por uma fundamentação da possibilidade da experiência pela contingência pela lei da especificação da natureza. A dedução transcendental da finalidade formal da natureza está em conformidade com a finalidade real da natureza que fundamenta a ideia de organismo, a diferença é que o a dedução do organismo introduz outros conceitos.

${ }^{85}$ KANT, I. Kritik der Urteilskraft, AA V: 186. 
Segundo Dieter Henrich, a dedução pretende ser uma prova, originalmente jurídica transferida para o sentido filosófico como um "método de justificação filosófica na forma e terminologia das deduções jurídicas" ${ }^{, 86}$ A dedução da finalidade interna real para a possibilidade de experiência do organismo na anatomia, história natural, fisiologia e outras ciências próximas consistiria, segundo a primeira Introdução, em uma exposição e uma dedução do conceito. A Crítica da faculdade de juízo teleológico deveria assim conter uma dedução transcendental do princípio da finalidade interna como fim real da natureza segundo a promessa da Introdução. Ao que tudo indica, o §66 é o que mais dá pistas sobre essa possível dedução, pois ele afirma que a necessidade contida no princípio deve ser fundamentada num princípio a priori. ${ }^{87}$ Não se deve esperar muita coisa dessa dedução, mas ela é sem dúvida fundamental, dado a situação de não fundamentação a que se poderia deixar o conhecimento dos organismos. A dedução kantiana, resumidamente, envolve o seguinte triângulo conceitual: uma (i) experiência dada em geral, mas com necessidade de fundamentação, uma (ii) dedução metafísica da origem a priori dos conceitos em função de uma (iii) dedução transcendental que fundamente a experiência sob os conceitos a priori da dedução metafísica. Experiência, origem e objetividade são então os problemas centrais da dedução.

A aparência de necessidade da experiência tem o entendimento como fundamento do argumento transcendental, e a aparência contingente da experiência terá a razão e a faculdade de julgar como fundamentos do argumento transcendental de justificação da teleologia. O conceito de constitutivo está ligado a essa

\footnotetext{
86 HENRICH, Dieter. "Kant's Notion of the Deduction". In: FÖRSTER, Eckart. Kant's Transcendental Deductions. The three 'Critiques' and the 'Opus Posthumum'. Stanford: Stanford University Press, 1989. p. 37.

${ }^{87}$ TANAKA, M. Kants Kritik der Urteilskraft und das Opus postumum: Probleme der Deduktion und ihre Folgen. Thesis, Philipps-Universität Marburg, 2004.
} 
necessidade de esquematismo, é o esquematismo que possibilita que o conceito seja constitutivo para o objeto como conexão de conceito a priori, esquema e forma empírica. As categorias na intuição são esquemas, assim como a substância é permanência na intuição, do mesmo modo as ideias são sistemas no entendimento. A impossibilidade de um esquematismo entre razão e intuição é o motivo da limitação a uma dedução analógica; aqui só é possível um esquematismo analógico entre razão e entendimento. A dedução do princípio do organismo não escapará a essa fórmula, pois, assim como nas Introduções tratava-se do problema da experiência do labirinto do múltiplo que precisava de dedução metafísica e transcendental, isto é, de conceito universal e portanto de origem a priori, que resolvesse o problema do labirinto da experiência, do mesmo modo, aqui também há um problema na experiência do organismo, que é a sua irredutibilidade ao mecanismo e à teologia, e daí a necessidade de dedução que justifique uma natureza pensada como autoprodução de sistemas particulares.

No $§ 64$ tratou-se de pensar que o organismo podia ser observado em sua epigênese como fim natural pela autoprodução da espécie, indivíduo e partes. No $\S 65$, a autoprodução do indivíduo exige que as partes se autoproduzam e produzam o indivíduo, como se verá, o conceito de comunidade deverá ser introduzido. Aqui Kant fala em uma derivação de um conceito determinado, o qual nós interpretaremos como a partir de um certo conceito de reciprocidade. No §66, essa derivação empírica da produção do indivíduo necessita da ideia de sistema, e daí se pode esperar que também a espécie necessite de sistema, e assim por diante. A nossa tese é de que essa reduzida formulação é compatível com a principal concepção de dedução transcendental. 
Essa dedução deveria legitimar ou deslegitimar a pretensão da história natural, da anatomia e da fisiologia de empregarem o conceito de finalidade ${ }^{88}$. Em Kant a dedução se diferencia conforme a pretensão a ser examinada. Por exemplo, na primeira Crítica a dedução consistia em justificar a pretensão de conceitos puros terem uso empírico, daí o problema da possibilidade da experiência e da fundamentação da objetividade, pois são essas funções que os conceitos puros alegam uma fundamental pretensão. E no juízo estético a pretensão era outra, pois são juízos particulares com pretensão de universalidade, assim era esta pretensão que deveria ser deduzida. A dedução do $\$ 66$ se distingue da dedução da seção V da segunda Introdução pela ausência do esquematismo analógico. O esquematismo das ideias da razão consiste na máxima divisão, a qual, possibilita parentesco completo das partes e portanto sistema, o contrário, uma divisão incompleta, não constituiria nenhum sistema. Ao aplicar-se o esquematismo ao problema do organismo, a função da divisão máxima é a de possibilitar a distribuição completa de fins no organismo, a qual é reconhecida na definição "tudo é fim e meio, nada é em vão". Segundo a nossa tese, a localização dos conceitos na dedução da finalidade interna objetiva da natureza é a seguinte:

\footnotetext{
${ }^{88}$ Hoje nós poderíamos transportar a intenção de Kant ao nosso contexto e dizer que os argumentos transcendentais são necessários para que o biólogo se encoraje a utilizar alguma teleologia. Há atualmente uma série de esforços dos filósofos contemporâneos de legitimar de um modo ou de outro, com argumentos empíricos, metafísicos e lógicos, o emprego da teleologia na biologia. Lembremos aqui primeiramente dos kantianos e aristotélicos. Mas também o metafísico N. Hartmann, o filósofo analítico alemão Stegmüller, o biólogo da "síntese evolucionária", Mayr, pela ideia de teleonomia cunhada por Pittendrigh, mas também Nagel, Monod (pela ideia de teleonomia no nível químico da biologia molecular, portanto um argumento físico), e tantos outros por conceitos como o de emergência, função, auto-organização etc. A questão ainda vive, mas voltemos ao nosso problema.
} 


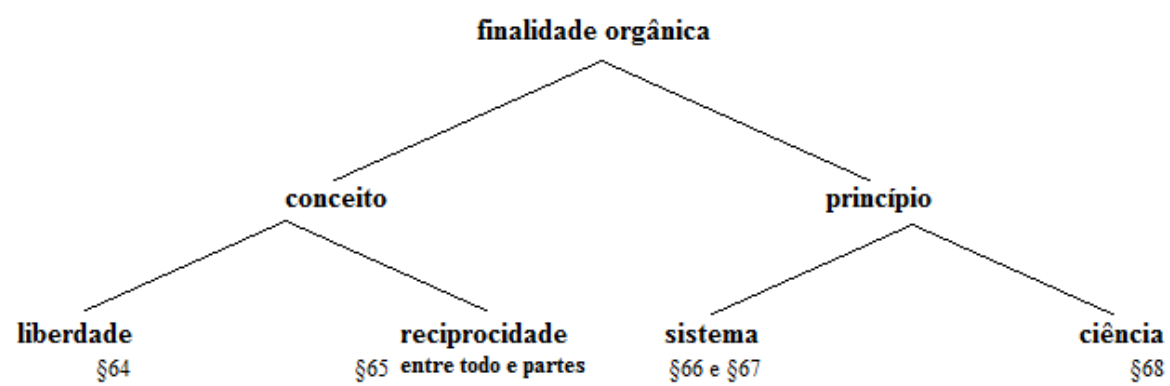

A exposição da finalidade interna começa pela experiência. Ela consiste em observar que, entre os objetos naturais, o caráter próprio da organização natural é que ela tenha sido produzida antes de tudo pela própria natureza, daí as cuidadosas incursões da filosofia kantiana do orgnanismo na ideia de liberdade na natureza. Ainda dentro da exposição, a possibilidade de organização da própria natureza tem de ser pensada pelo fio condutor que começa nas partes, caso contrário a organização teria de ser pensada exclusivamente a partir de uma unidade intencional. A finalidade da natureza ganha então um conceito determinado através dos conceitos de comunidade e sistema. $\mathrm{O}$ último passo consistia em generalizar a finalidade interna a todas as partes do organismo. Ora, segundo o esquematismo analógico da unidade sistemática, isso só é possível dividindo o conceito maximamente a todas as partes. Com isso, Kant deduz o princípio, pois ele funciona de modo completo no organismo, e essa completude é garantida pela ideia de sistema:

Uma ideia deve fundamentar a possibilidade do produto da natureza. Mas porque essa ideia é uma unidade absoluta da representação, e inversamente a matéria é uma multiplicidade de coisas que não possibilita nenhuma unidade determinada de composição, portanto, se aquela unidade da ideia deve servir como fundamento de determinação a priori de uma lei natural da causalidade de uma tal forma dos compostos, então o fim da natureza deve ser estendido a tudo o que assenta em seu produto. ${ }^{89}$

\footnotetext{
${ }^{89}$ Eine Idee soll der Möglichkeit des Naturprodukts zum Grunde liegen. Weil diese aber eine absolute Einheit der Vorstellung ist, statt daß die Materie eine Vielheit der Dinge ist, die für sich keine
} 
O prncípio da unidade sistemática, na qual assenta a dedução, garante que tudo deve ser tomado como meio e simultaneamente fim no organismo:

Por exemplo, sempre pode-se conceber muitas partes (como os pêlos, os ossos e os cabelos) em um corpo animal como concreções somente segundo leis mecânicas. Mas a causa, a qual conduz a matéria dirigida e a modifica e forma e por fim deposita em seu lugar de pertencimento, deve ser sempre julgada teleologicamente, pois tudo nele deve ser considerado como organizado, e por isso tudo também internamente é órgão. ${ }^{90}$

O essencial na dedução do conceito de fim da natureza é então a fundamentação na ideia de sistema. Segundo Kant, porém, a ideia de sistema conduz a razão a tomar a natureza toda como um sistema. A estratégia de Kant no §67 será a de rejeitar a finalidade externa como sistema de fins da natureza, e então ampliar a finalidade interna do organismo a toda a natureza. O último parágrafo da Analítica da faculdade de juízo teleológico, que é o último parágrafo da dedução transcendental, trata de um tema igualmente importante na dedução. Trata-se da condição de que um tal conceito possibilite alguma ciência. Como na exposição transcendental do espaço e tempo eram a base para a geometria e a física mecânica, e segundo os Prolegômenos, as categorias eram condição prévia da ciência da natureza, aqui igualmente se deve discutir a possibilidade de a finalidade ser condição de alguma ciência.

A dedução transcendental então não se limita a fundamentar a possibilidade da experiência e a sua objetividade, mas também deve mostrar que tais conceitos

bestimmte Einheit der Zusammensetzung an die Hand geben kann: so muß, wenn jene Einheit der Idee sogar als Bestimmungsgrund a priori eines Naturgesetzes der Kausalität einer solchen Form des Zusammengesetzten dienen soll, der Zweck der Natur auf alles, was in ihrem Produkte liegt, erstreckt werden. KANT, I. Kritik der Urteilskraft. AA V: 377.

${ }^{90}$ Es mag immer sein, daß z.B. in einem tierischen Körper manche Teile als Konkretionen nach bloß mechanischen Gesetzen begriffen werden könnten (als Häute, Knochen, Haare). Doch muß die Ursache, welche die dazu schickliche Materie herbeischafft, diese so modifiziert, formt, und an ihren gehörigen Stellen absetzt, immer teleologisch beurteilt werden, so, daß alles in ihm als organisiert betrachtet werden muß, und alles auch in gewisser Beziehung auf das Ding selbst wiederum Organ ist. KANT, I. Kritik der Urteilskraft. AA V: 377. 
possibilitam essa ou aquela ciência. No §65, Kant afirmava que os "seres organizados são então os únicos na natureza" que devem ser pensados como fins da natureza e possibilitam o "fundamento de uma teleologia para a ciência da natureza" ${ }^{91}$. No $§ 66$ é afirmado que a anatomia faz uso do princípio teleológico, e no §68 a discussão se dá entorno da ciência da natureza e da física, e ainda aparecerá a descriação e a história da natureza na Metodologia da faculdade de juízo teleológico. O esforço de Kant foi o de mostrar que a crítica da teleologia tem como objetivo a fundamentação de alguma ciência empírica. No caso da anatomia, está já fazia um uso absolutamente inevitável da finalidade interna, faltava-lhe uma dedução.

${ }^{91}$ KANT, I. Kritik der Urteilskraft. AA V: 296. 


\subsection{Sistema como princípio transcendental da pré-formação e reprodução}

O conceito de sistema tem como função conectar um organismo individual a todos os organismos como um sistema completo. Segundo o conceito lógico de divisão que constitui a ideia de sistema, na qual o conceito é distrubuído entre as partes através da divisão a mais completa possível, ao transpôr-se essa lógica para o pensamento sobre o organismo, tem-se que a forma originária da organização se propaga a todos os seres organizados como uma reprodução de formas gerais sobre formas particulares. A teleologia da história natural kantiana tem portanto como conceito central o de parentesco, que é por sua vez o conceito que possibilita o máximo de unidade sistemática.

Segundo o Prefácio dos Princípios metafísicos da ciência da natureza, devese entender "história natural como uma exposição sistemática das coisas naturais em diversos tempos e lugares" ${ }^{92}$. Ora, essa sistematização temporal que define a história natural é necessariamente uma história do parentesco dos seres organizados. Kant procura dar justificação a duas teleologias diferentes para a natureza: a teleologia do parentesco para a história da natureza e a teleologia da finalidade interna para a anatomia, fisiologia ou física do organismo e para a descrição da natureza toda.

A terceira teleologia da natureza é rejeitada, trata-se da finalidade externa, a qual, se por um lado, é rejeitada na natureza, por outro lado é admitida na transição para a liberdade. O fim definitivo ou escopo da natureza - o qual deveria poder ser conhecido para a admissão da natureza como sistema de fins externos - não é encontrado na natureza, mas na liberdade prática. Além disso, a representação da natureza como finalidade interna tem a função de confirmação externa no argumento

${ }^{92}$ KANT, I. Metaphysische Anfangsgründe der Naturwissenschaft, AA IV: 468. 
moral da existência de deus. Esses argumentos são desenvolvidos estritamente na Crítica da faculdade de julgar.

Os Opúsculos sobre as raças, onde Kant elabora outras reflexões sobre a história natural, limitam-se a desenvolver uma doutrina do parentesco das raças humanas, todavia o parentesco é ampliado a todos os seres organizados no Apêndice à dialética transcendental e no $\$ 80$ da terceira Crítica, é então com essa doutrina do parentesco completo cujo fundamento é a ideia de sistema que nos ocupamos nessa seção. Em Kant, o princípio do parentesco aparece primeiramente nos Opúsculos sobre as raças $(1775,1785$ e 1788), cuja finalidade seria precisamente a de provar o parentesco entre as raças em uma única espécie, a humana; ele também aparece em outras obras, mas nós nos limitaremos ao $\$ 80$ da Crítica da faculdade de julgar e ao Apêndice à dialética transcendental da Crítica da razão pura, onde Kant apresenta uma dedução do princípio.

O principal problema deste Apêndice é a dedução transcendental das ideias puras da razão. Essa dedução é reconhecidamente um problema, porque Kant afirma no fim da primeira parte que é impossível uma dedução transcendental das ideias da razão, e no começo da segunda parte ele afirma que é necessário fazer uma dedução. Com isso, os comentadores entram em polêmica se há ou não aí uma dedução. Nós seguimos, nesse ponto, a posição de Mario Caimi, que é um defensor da dedução transcendental das ideias. ${ }^{93}$

O Apêndice traz uma articulação entre entendimento e razão. O entendimento é encarrregado da reflexão sobre os particulares da natureza, e isso necessariamente deve pressupor o princípio transcendental da razão da unidade sistemática da

${ }^{93}$ CAIMI, M. "Über eine wenig beachtete Deduktion der regulativen Ideen”, in: Kant-Studien, Bd. 86, Hft. 3 (1995), 308-320. 
natureza. $\mathrm{O}$ entendimento aqui não está refletindo para não violar a distinção entre fenômeno e númeno e se preparar para a formação de conceitos, ele está refletindo em vista da produção de conceitos na classificação. Lebrun dá o nome de "reflexão metodológica" a essa atividade:

a reflexão lógica, tomando consciência do ato de comparar, faz com que ele se torne 'begreiffen', mas sem prejulgar nada ainda quanto à relação possível a um objeto -- a reflexão transcendental, por seu lado, é somente o 'estado de espirito no qual nós primeiramente nos preparamos para descobrir as condições subjetivas que nos permitem chegar a conceitos'; enfim a reflexão metodológica supondo a natureza unificada como um sistema, não funda nenhuma teoria e tampouco como a lógica contém um conhecimento de objetos e de sua natureza. $^{94}$

A reflexão metodológica dá então um passo que a reflexão lógica e a transcendental não davam, formar conceitos empíricos, porque, segundo a formulação desse problema na primeira Crítica, todas as condições para a formação de conceitos empíricos estariam dadas, e a última seria a natureza como um sistema. A reflexão lógica proporciona algo para a formação de conceitos, e a reflexão metodológica proporcionaria essa ideia de unidade sistemática. Trata-se de uma operação do entendimento, pois a reflexão definida no capítulo sobre a Anfibolia é apenas um estado da mente, o que se pode dizer, um estado do entendimento em atividade lógica e metodológica para a formação de conceitos empíricos. Aqui não há o juízo reflexionante, mas apenas o entendimento em articulação com a razão e o seu princípio transcendental.

Isso significa que para Kant - nesse Apêndice - a indução pela lógica geral não é suficiente para a produção de conceitos empíricos, são necessários ainda princípios transcendentais da lógica transcendental. Em outras palavras, não faria

${ }^{94}$ LEBRUN, G. Kant e o fim da metafísica, p. 377. 
sentido classificar sem a pressuposição da unidade da natureza como um princípio transcendental. O princípio da unidade sistemática, o qual funda a ideia de parentesco, é uma ideia regulativa. Kant as explica no início do Apêndice, onde ele distingue dois tipos de uso de ideias e conceitos. O uso certo é o uso imanente: o uso imanente das categorias é constitutivo e o uso imanente das ideias não pode ser constitutivo, tem de se limitar a ser apenas regulativo. $\mathrm{O}$ uso regulador se dá na medida em que a razão não se refere a objetos, mas apenas ao entendimento e regula a sua atividade, colocando ordem e unidade coletiva. Isso é apenas subjetivo, e esta subjetividade assenta na operação de pensamento na medida em que não são os objetos que possuem essa ordem, mas o entendimento é que é obrigado a operar segundo uma ordem: "A razão nunca se reporta diretamente a um objeto, mas apenas ao entendimento e, por intermédio deste ao seu próprio uso empírico." 95 Que ordem é essa que a razão impõe ao entendimento? Kant primeiro introduz uma analogia ótica na qual as ideias regulariam o entendimento como o foco imaginário dirige uma imagem. O foco imaginário seria o ponto de fuga da perspectiva onde todos os pontos da imagem estariam em convergência em um ponto de fuga atrás do espelho, além da imagem. $\mathrm{O}$ entendimento estaria aí tomando em consideração o múltiplo, e esse múltiplo deve convergir para o foco imaginário, que é a ideia da razão. Kant então vai tratar isso como sistema, a regulação conceitual ou a direção ótica seriam então a sistematização do entendimento:

Se considerarmos em todo o seu âmbito os conhecimentos do nosso entendimento, encontramos que a parte de que a razão propriamente dispõe e procura realizar é a sistemática do conhecimento, isto é, o encadeamento a partir de um princípio. ${ }^{96}$

\footnotetext{
${ }^{95}$ KANT, I. Crítica da razão pura, trad. M. P. Santos e A. F. Morujão, A 644 / B672.

${ }^{96}$ KANT, I. Crítica da razão pura, trad. M. P. Santos e A. F. Morujão, A 645 / B673.
} 
Essa é a única utilidade possível para as ideias, isto é, sistematizar subjetivamente o conhecimento, isso porque a ideia reguladora corresponde ao todo e o entendimento corresponde às partes, onde o todo determina o lugar das partes. Kant primeiro buscou explicar pelo foco imaginário e a convergência sobre ele, agora a explicação das ideias reguladoras não se dá pela noção de convergência, mas pelo conceito de determinação a priori das partes:

Esta unidade da razão pressupõe sempre uma ideia, a da forma de um todo do conhecimento que precede o conhecimento determinado das partes e contém as condições para determinar a priori o lugar de cada parte e sua relação com as outras." $" 97$

Kant acentua a ideia de sistema e agregado, o diferencial aqui é que entra o fator "conhecimento"; em primeiro lugar, explicou-se pela ideia de convergência sobre um ponto de foco, em segundo, pela estruturação das partes, e por fim pela ideia de que o conhecimento se torna perfeito contra o conhecimento imperfeito do agregado:

Esta ideia postula, por conseguinte, uma unidade perfeita do conhecimento do entendimento, mercê da qual, este não é apenas um agregado acidental, mas um sistema encadeado segundo leis necessárias. ${ }^{98}$

As ideias regulativas dirigem o entendimento, assim como na ótica, os conceitos do entendimento têm de convergir para um ponto ou foco imaginário que são as ideias regulativas, e na medida em que as ideias são tomadas como o todo que estrutura as partes determinando o lugar onde cada parte deve estar e os tipos de relações entre as partes, então aí há um sistema entre entendimento e razão, o que por sua vez é o tipo de conhecimento perfeito ("uma unidade perfeita do conhecimento"). Kant termina essa parte do Apêndice que explica o uso regulativo pelo uso hipotético

\footnotetext{
${ }^{97}$ KANT, I Crítica da razão pura, trad. M. P. Santos e A. F. Morujão, A 645 / B673

${ }^{98}$ KANT, I.Crítica da razão pura, trad. M. P. Santos e A. F. Morujão, A 645 / B673.
} 
da razão. O uso hipotético da razão, ainda vai ter essa ideia de convergência a um ponto, e da relação todo/partes e agregado/sistema, mas aqui a ideia vai ser tomada como hipótese. A ideia já foi o focus imaginarius, já foi o todo, o sistema, mas agora ela é hipótese e será com ela que Kant terminará essa parte sobre uso regulativo e imanente. Aqui aparece a faculdade de julgar determinante apenas, o empirico nao vai ficar a cargo da reflexionante, mas do entendimento no ato lógico de produção de conceitos empíricos.

Se a razão é a faculdade de derivar o particular do geral, então o geral ou já é dado e certo em si, pelo que só exige a faculdade de julgar para operar a subsunção e o particular é desse modo determinado necessariamente, e é o que eu denomino o uso apodítico da razão; ou o geral só é considerado de maneira problemática e é uma simples ideia. $^{99}$

Se há então certeza sobre o universal, a faculdade de julgar determina o objeto, no caso em questão isso não é possível, assim o juízo determinante é retirado dessa operação e entra o entendimento fazendo outra coisa que não a determinação com a faculdade de julgar. Essa outra coisa que o entendimento está fazendo é a reflexão em articulação com as hipóteses da razão. Trata-se de uma espécie de indução, Kant quase não usa a palavra indução nesses textos, a única vez que aparece indução é na Lógica Geral onde ele define as inferências da faculdade de julgar do particular ao universal como analogia e indução. O exemplo de inferência indutiva da multiplicidade de forças a uma força fundamental seria um tipo de indução em articulação com o uso hipotético da razão. A questão é que Kant quase não emprega a palavra indução, mas ela certamente está por trás dessas comparações entre particulares. Na primeira Crítica é a razão que conjectura as hipóteses, porque Kant está lidando com o uso de ideias:

${ }^{99}$ KANT, I Crítica da razão pura, trad. M. P. Santos e A. F. Morujão, A 649 / B677. 
o particular é certo, mas a generalidade da regra relativa a esta consequência é ainda um problema; então aferem-se pela regra diversos casos particulares, todos eles certos, para saber se se deduzem dela e se parecer que dela derivam todos os particulares que se possam indicar, conclui-se a universalidade da regra e, a partir desta, todos os casos que não forem dados em si mesmos. ${ }^{100}$

Kant está lidando com o problema da indução, ela não é explicitada, mas está presente na anatomia comparada, pois é pela lógica indutiva na comparação dos particulares que a anatomia comparada e a história natural desenvolvem os seus conhecimentos. É nesse sentido que na terceira Crítica o juízo reflexionante compara os particulares para a produção de conceitos comuns e deve pressupor a ideia de sistema da razão. Aqui também se encontra uma cooperação entre indução e ideia. Através da indução a partir de casos particulares, a razão introduz ideias que têm o valor de hipóteses. Se há a aparência de que esses particulares estão sendo derivados desse universal admitido problematicamente. O problemático é a ideia de sistema, ou seja, nunca se provará que a natureza seja um sistema, sempre se deverá tomar o sistema como hipótese e problema, de qualquer forma, a unidade sistemática possui a utilidade de dar um princípio para o entendimento.

Após a explicação sobre o uso regulativo da razão, Kant ainda trata dos princípios lógicos e transcendentais que formam a unidade sistemática na razão para o uso regulativo do entendimento. O princípio da unidade sistemática, do qual o parentesco é um princípio de acabamento da unidade entre homogeneidade e variedade, é uma ideia regulativa. Kant nos alerta sobre isso o tempo todo, daí a importância de se compreender as partes da dedução desde o estatuto regulativo até o esquematismo analógico.

${ }^{100}$ KANT, I. Crítica da razão pura, trad. M. P. Santos e A. F. Morujão, A 647 / B675. 
Kant distingue entre princípio lógico e princípio transcendental para limitar os princípios transcendentais à razão, pois se a unidade sistemática e os seus três princípios fossem princípios transcendentais do entendimento então a natureza seria tomada constitutivamente como sistema. O primeiro princípio é o princípio da homogeneidade, o qual deve ser tomado como aquele que mais define a unidade sistemática. A homogeneidade também significa o gênero superior formado ascendendo de espécies mais baixas para espécies mais altas até gêneros e gêneros mais altos:

que as diversas espécies se devam apenas considerar como determinações diversas de um pequeno número de gêneros, e estes, por sua vez, derivados de classes mais elevadas, etc., e que se deva, portanto, procurar uma certa unidade sistemática de todos os conceitos empíricos possíveis. ${ }^{101}$

O principio da homogeneidade é assim essa busca por uma unidade no múltiplo em função da ascenção de espécies a gêneros superiores:

O princípio lógico dos gêneros supõe pois um princípio transcendental para poder ser aplicado à natureza. Segundo esse mesmo princípio, na diversidade de uma experiência possível deverá supor-se necessariamente uma homogeneidade. ${ }^{102}$

O segundo princípio da unidade sistemática, o princípio de especificação, se contrapõe ao primeiro, o que deve indicar como os dois estão por isso em unidade. Trata-se aqui do duplo interesse da razão por extensão e conteúdo. Nesse momento Kant ainda está chamando um de princípio dos gêneros e o outro de princípio das espécies. O primeiro postula identidade e esse postula multiplicidade e diversidade das coisas, apesar de pertencerem a algum gênero. Gênero e espécie estão conectados. Quem postula essa multiplicidade e diversidade é a razão, e o

\footnotetext{
${ }^{101}$ KANT, I. Crítica da razão pura, trad. M. P. Santos e A. F. Morujão, A 651 / B679.

${ }^{102}$ KANT, I. Crítica da razão pura, trad. M. P. Santos e A. F. Morujão, A 654 / B682.
} 
entendimento tem de considerar as coisas empíricas no máximo de diferenças possíveis entre elas:

Ao princípio lógico dos gêneros, que postula identidade, contrapõe-se um outro princípio, o das espécies, que requer a multiplicidade e diversidade das coisas, apesar da sua concordância no mesmo gênero, e prescreve ao entendimento estar tão atento às espécies como aos gêneros. ${ }^{103}$

A razão postula o princípio da espécie, o qual significa que o entendimento tem de estar atento a multiplicidade e diversidade das coisas, mas isso em concordância com o gênero. A razão tem aí dois interesses antagônicos que precisam ser equilibrados. O interesse da razão no gênero é o "interesse da extensão", a razão busca a máxima extensão através de um conceito universal. E o interesse da razão na espécie é o "interesse do conteúdo" através da "multiplicidade das espécies". Kant aqui dá uma expressão muito sintética, dificil de entender: "muito sob o conceito" e "muito no conceito", esse muito sob o conceito seria a extensão e o muito no conceito, muito no mesmo conceito, o conteúdo. Ou ele representa coisas e tem conteúdo; ou as coisas estão representadas sob ele, e isso é extensão. Isso é um procedimento da lógica, o principal aqui é que a razão pode ter um interesse em direção a extensão ou ao conteúdo, e esses dois interesses da razão se limitam reciprocamente se forem tomados como uma dupla.

O interesse da razão pelo conteúdo tem como princípio lógico a especificação, e essa especificação não tem fim pois, não é possivel saber até onde pode ir essa divisão do ponto de vista lógico. Disso resulta que sempre haverá subespécies, porque a divisão se abre ao infinito. Daí a lei lógica da especificação de que sempre haverá sub-espécies menores. A lei transcendental da especificação seria a

${ }^{103}$ KANT, I. Crítica da razão pura, trad. M. P. Santos e A. F. Morujão, A 654 / B682. 
prescrição ao entendimento de sempre buscar espécies menores, há pouca diferença entre o lógico e o transcendental. Ao que parece, se trata de pensar que a divisão lógica indefinida prescreve a busca por espécies sempre menores. Essa lei transcendental da especificação é apenas ideal, e não real, pois a lógica não determina a divisão toda, a divisão é indeterminada e se pode tampouco derivá-la da experiência, é impossível obter esse infinito de dados empíricos, então o princípio é transcendental e na verdade orienta a "especificação empírica".

O terceiro e último princípio é o do parentesco, Kant primeiramente o define assim: "lei da afinidade de todos os conceitos [lógica], lei que ordena uma transição contínua de cada espécie [transcendental] para cada uma das outras por um acréscimo gradual da diversidade." ${ }^{104}$ A afinidade então é primeiramente o gradualismo no diverso. Logo após, o parentesco é definido não pela graduação ou continuidade das formas e conceitos, mas pela origem comum, e sobretudo nesse caso, ele é além de afinidade, parentesco. Por trás disso há a ideia de que se a continuidade é completa então deve haver uma origem comum, e se houvessem saltos entre as espécies nesse caso a origem não seria comum, ou seja, não pode haver vazio na cadeia para que ela seja contínua e constitua um princípio transcendental de afinidade e parentesco. A origem comum, que garante o parentesco contínuo, assenta na ideia de divisão sem salto de um único conceito, caso a divisão fosse feita a partir de dois conceitos distintos então haveria salto na cadeia. A continuidade pressupõe um tronco comum. "Essa lei lógica do contínuo de espécies (das formas lógicas) pressupõe uma lei transcendental (lei do contínuo na natureza)."105 A busca por proximidades de espécies na experiência tem de pressupor

\footnotetext{
${ }^{104}$ KANT, I. Crítica da razão pura, trad. M. P. Santos e A. F. Morujão, A 658 / B686.

${ }^{105}$ KANT, I. Crítica da razão pura, trad. M. P. Santos e A. F. Morujão, A 660 / B688.
} 
que a natureza seja contínua, com afinidade ou parentesco, apenas como ideia regulativa da razão para o entendimento. Kant apresenta os três princípios em outra ordem, a ordem de uso desses princípios na experiência: primeiro multiplicidade, depois afinidade e por fim unidade (homogeneidade/gênero). A explicação dessa ordem é a classificação, isto é, em vista da classificação na experiência se lida primeiro com os particulares, com a multiplicidade, a qual é o primeiro princípio, após a classificação os indivíduos estão postos sob uma mesma espécie, portanto em continuidade, em afinidade ou parentesco, e daí nós vamos ascendendendo até a unidade sistemática completa, no gênero mais alto. A ordem de uso na experiência dos princípios da unidade sistemática também parece obedecer a ordem das operações lógicas do entendimento. O princípio da multiplicidade e a operação de comparação, o parentesco e a reflexão que possibilita os conceitos comuns, e por fim a unidade dada pela terceira operação, a abstração.

Os três princípios da razão preparam o campo para o entendimento antecipando-o uma unidade sistemática ideal da natureza. Essa idealidade assenta na concepção de uso regulativo da razão, como descrevemos atrás. Ao fim da primeira parte do Apêndice, Kant trata da dedução da unidade sistemática. Mario Caimi toma a afirmação de Kant de que "sem que se possa realizar uma dedução transcendental dos mesmos, pois em vista das ideias é sempre impossível"106 como uma mera advertência, e que haveria assim uma dedução analógica. A ideia de sistema seria um “análogo de esquema", e a sistematização seria algo análogo ao esquematismo, daí a possibilidade de pensar uma dedução. O esquema aqui seria o "máximo da divisão", uma divisão máxima que produz a especificicação e o parentesco completo, portanto sistema no sentido máximo:

${ }^{106}$ KANT, I. Crítica da razão pura, Trad. M. P. Santos e A. F. Morujão, A 664 / B 692. 
No entanto, embora não se possa encontrar na intuição nenhum esquema para a unidade sistemática completa de todos os conceitos do entendimento, pode e deve encontrar-se um análogo desse esquema, que é a ideia do máximo da divisão e da ligação do conhecimento do entendimento num único princípio. ${ }^{107}$

A analogia com o esquema aqui se dá na medida em que a divisão é máxima, então o oposto é eliminado, e haveria um análogo de determinação:

o máximo e o absolutamente completo podem conceber-se de maneira determinada, porque se puseram de lado (weggelassen) todas as condições restritivas que promovem a diversidade indeterminada. ${ }^{108}$

Esse máximo da divisão elimina o diverso indeterminado, então tudo é determinado como dentro de um único sistema, portanto todo o diverso estaria sob um mesmo conceito. $\mathrm{O}$ entendimento pensa a natureza como um sistema onde tudo teve origem a partir de um conceito, é nesse sentido que sistema é uma ideia da razão que serve como esquema, sem todavia ser esquema de verdade. Essa analogia entre sistema e esquema é possivel porque o entendimento constitui um objeto para a razão, como a sensibilidade para o entendimento. Sistema é como um grande esquema que não determina a natureza, mas permite pensar ela como uma totalidade.

Do ponto de vista lógico, sistema é a divisão de um gênero em espécies, subespécies e assim por diante até os indivíduos; e sistema, do ponto de vista transcendental, é a divisão de um todo em partes e a determinação da localização e relação das partes. O essencial então na ideia de sistema é a divisão lógica: "A forma lógica de um sistema consiste na divisão de um dado conceito universal". Pela divisão se pode pensar, enquanto ideia, a construção de um sistema, o todo que precede as partes: "divisão como construção de um sistema". Pela ideia de divisão

${ }^{107}$ KANT, I. Crítica da razão pura, trad. M. P. Santos e A. F. Morujão, A 665 / B693.
${ }^{108}$ KANT, I. Crítica da razão pura, trad. M. P. Santos e A. F. Morujão, A 665 / B693. 
máxima se pode pensar que poderia haver uma construção microscópica do sistema através de partes sempre divididas ao máximo. Segundo Kant, a divisão é tarefa do juízo disjuntivo: “A divisão da esfera de um conceito é naturalmente uma ação do juízo e exatamente do juízo disjuntivo.”

O princípio da unidade sistemática e a sua dedução são parte preparatória para a dedução transcendental das três ideias puras da razão especulativa. A dedução destas consiste em colocar as três ideias como gênero supremo da unidade sistemática. Kant parece estar pensando em quatro esquemas, o da unidade sistemática no seu esquema da divisão completa do gênero em espécies e indivíduos. O esquema da psicologia é o da divisão do gênero supremo alma em infinitas faculdades. O esquema da cosmologia é o da divisão infinita do gênero mundo em infinitas partes, o que torna a pesquisa empírica uma tarefa infinita. Por fim, a teologia tem como esquema a divisão do gênero razão divina e sua intenção única em infinitos fins distribuídos maximamente ao mundo, o qual por esse motivo pode ser pensado como teleológico. Como se sabe, essa é apenas a solução da primeira Crítica, pois a finalidade será derivada do procedimento técnico da faculdade de julgar reflexionante na terceira Crítica, o qual não é necessário nessa exposição. Do ponto de vista conceitual, o Apêndice nos indica que o parentesco transcendental da natureza tem a função de introduzir continuidade nas formas e por isso semelhança através de transição gradual de uma forma a outra.

A origem histórica do conceito de parentesco parece estar em Platão, na ideia de divisão na diairesis, como se pode notar em Kant na sua definição de sistema lógico como tendo a forma da divisão do gênero. Mas tal concepção também se encontra em Aristóteles, em Plotino na ideia de cadeia do ser segundo a clássica obra 
de Lovejoy, na árvore de Porfírio ${ }^{109}$, e na modernidade na ideia de cadeia dos seres em Leibniz, Bonnet, Linneu etc. Kant toma a ideia como princípio meramente heurístico e regulativo, e afirma que se deve tomar a natureza pela continuidade das formas, mas a experiência que temos é a da descontinuidade. Trata-se por isso de um princípio meramente ideal quando tomado pela divisão máxima, Kant não é um defensor da metafísica da cadeia dos seres, apesar de afirmar uma ideia de parentesco completo em algumas passagens, como no $\S 80$, por exemplo, onde ele afirma que se pode pensar um "parentesco completamente conectado" (durchgängig zusammenhangende Verwandtschaft) de todos os organismos.

Mas a Metodologia da faculdade de juízo teleológico, da qual esse parágrafo é uma das partes iniciais, é muito pouco explicada pelos comentadores da terceira Crítica. A ideia geral de metodologia nas Críticas é a de que ela é o método para se produzir ciência a partir dos elementos deduzidos nas Analíticas e Dialéticas. Para o problema da Crítica da razão pura, isto é, o da metafísica como ciência, Kant estabelecerá que a metafísica especulativa não pode construir as suas ideias, mas pode sistematizar e simbolizar. A sistematização é uma etapa anterior à construção, pois é necessário que se conheça a quantidade, a qualidade e a ordem dos elementos antes que se passe à construção, a metafísica especulativa permece por isso limitada à sistematização e não pode passar à construção.

O método para o juízo teleológico é o da reflexão ou comparação, como isso foi desenvolvido desde a Introdução, e a metodologia não foge a essa configuração. Antes de entrarmos na questão do "parentesco efetivo" no $\S 80$ - pois até o momento tratamos do parentesco como princípio transcendental - vejamos então como se

${ }^{109}$ PANCHEN, A. L. Classification, evolution and the nature of biology, Cambridge University Press, NY, 1992. p. 16. 
encaminha a questão dessa Metodologia. A Metodologia tem como questão principal a passagem à construção ou sistematização da ciência. Para a matemática e a física mecânica a construção é o seu método, para a filosofia, ao contrário, a construção não é possível, pois seus conceitos são oriundos da razão, daí a Metodologia Transcendental da razão pura ter como meta a investigação sobre o sistema da razão pura. A Metodologia da faculdade de juízo teleológico não escapa a essa questão, é por esse motivo que Kant se pergunta pela localização da teleologia nas ciências. A teleologia não produz ciência objetiva, no máximo uma crítica da faculdade e da passagem entre as duas partes da filosofia, ou seja, a teleologia produz conhecimento das nossas capacidades e da articulação do sistema. Ela ainda é essencial à descrição e história da natureza.

Além da problemática da telologia como ciência, outro elemento estruturador de toda essa Metodologia é a antinomia entre mecanismo e teleologia. A oposição entre os dois princípios cobre todos os seus parágrafos, do $\$ 80$ até os últimos onde ocorre a passagem para a moral pela via da ético-teologia, onde a teleologia da natureza resolve o conflito entre mecanismo e o deus moral. Ora, o problema com o qual o $\$ 80$ lida é o da explicação, isto é, o mecanismo é o único conceito que pode explicar a natureza, e a teleologia não pode explicá-la, mas a explicação mecânica tem um limite que é o de não poder explicar os organismos, porque possuem um caráter teleológico, daí a necessária subordinação do mecanismo à teleologia regulativa. O motivo desse tema é o problema da teleologia como ciência. A teleologia enquanto teoria da natureza não é ciência, mas tem emprego nas ciências. O mecanismo e o princípio teleológico deverão então ser conciliados aqui em vista de um deficit científico do mecanismo. Kant exemplificará essa conciliação por um 
projeto de época bastante conhecido que articulava história natural e anatomia comparada:

É louvável, mediante uma anatomia comparada, percorrer a grande criação de naturezas organizadas para ver se não se encontra nela, inclusive segundo o princípio da geração, um sistema de semelhanças; sem necessariamente permanecer no mero princípio de ajuizamento (que não soluciona nada na inspeção da sua geração) e desistir covardemente de toda pretensão de inspeção da natureza nesse campo. A concordância de tantas espécies animais em um certo esquema comum, que parece estar na base não apenas de seu esqueleto, mas também na ordenação das partes restantes, onde uma simplicidade admirável do esboço pôde produzir uma tão grande multiplicidade de espécies pelo encurtamento de uma parte e alongamento da outra, pela envolvimento [Einwickelung] de uma parte e pelo desenvolvimento [Auswickelung] de outra parte deixa cair na mente um raio de esperança mesmo que fraco de que se poderia chegar aqui a algo com o princípio do mecanismo da natureza, sem o qual em geral não poderia existir nenhuma ciência da natureza. ${ }^{110}$

A pretensão de explicação mecânica pela anatomia comparada tendo como base a sua redução da multiciplicidade de espécies a um esquema comum, e a partir daí vislumbrando o parentesco e deste a unidade de todos os seres vivos, gera um pretenso conhecimento do sistema de todos os organismos através do mecanismo da natureza. Pretensão certamente ilegítima segundo o criticismo kantiano, pois o ser humano deveria ter um outro tipo de entendimento ou de intuição para alcançar uma explicação mecânica dessa magnitude para a história natural, mesmo que pelo método comparativo e indutivo da anatomia comparada. Nesse ponto, a explicação mecânica deve se articular com o princípio teleológico e passar a pensar o parentesco completo como produto de uma organização originária, conceito que Kant toma como absolutamente necessário à história da natureza dos organismos:

Ora, o arqueólogo da natureza fica nesse ponto livre para deixar originar toda aquela grande família de criaturas (pois assim deveríamos representá-las se o parentesco completo deve ter um

${ }^{110}$ KANT, I. Kritik der Urteilskraft, AA V: 419. 
fundamento) a partir dos rastros das suas antigas revoluções segundo todo conhecido e conjecturável mecanismo. ${ }^{111}$

A grande maioria daqueles que tratam da questão, põe no centro da história natural o conceito de espécie segundo a regra de Buffon, isto é, a interfertilidade entre indivíduos que assegura o pertencimento à mesma espécie, e portanto dá a unidade natural para a espécie, isto é, há a reprodução e propagação das formas se os descendentes são férteis entre si. Ora, não parece que esse seja o princípio da história natural em geral, antes parece que o problema das raças - que elas devam ser submetidas a uma única espécie - é que exige a "regra buffoniana" da interfertilidade, ou seja, a interfertilidade é necessária apenas para o conceito de espécie. A história natural kantiana não se reduz ao conceito de espécie, pois no seu sentido mais ampliado possível ela deve ser uma história do parentesco completo.

O argumento do Apêndice à dialética transcendental, assentava na dedução da ideia de sistema e na dedução transcendental da ideia de deus, o que consiste na utilidade da máxima determinação, e ela se dá no princípio do parentesco. Nesse caso, o parentesco pode ser pensado apenas pela razão segundo a lógica da divisão do conceito. Posteriormente, na terceira Crítica, a faculdade de julgar trará a possibilidade de pensar a natureza como autoprodutora das espécies, indivíduos e partes. Nos opúsculos a causa do parentesco era a providência da natureza, ou uma técnica da natureza em Sobre o uso dos princípios teleológicos na filosofia, e nesse caso não houve o argumento de utilidade da máxima determinação, pois o parentesco foi introduzido por outro motivo, a saber, a unidade da espécie humana e a evidência física da interfertilidade entre as diferentes raças humanas.

${ }^{111}$ KANT, I. Kritik der Urteilskraft, AA V: 419. 
$\mathrm{O}$ argumento do $\$ 80$ sobre a teleologia é relativo ao mecanismo da natureza, sem dúvida, um mecanismo físico-químico como matriz não poderia ser causa de parentesco, porque, segundo o $\S 65$, um relógio não pode ser causa produtora autônoma de outro relógio. Não se deve portanto transformar a semelhança em parentesco, este necessita de uma causa teleológica. A metodologia mecanicista pela via da anatomia comparada pretendia encontrar uma unidade mecânica, e é daí que surge o problema do parentesco no §80. Ele está aqui em função do mecanismo, o que por sua vez é o problema da metodologia da teleologia como ciência. A anatomia comparada pretendeu alcançar aquilo que Kant chama de construção, certamente não do mesmo modo que a matemática o faz de modo absolutamente a priori, mas pesquisando o esquema da construção por uma via empírica. A posição de Kant a esse respeito é a de que por mais que haja progresso em analogias mecânicas, ainda haverá perenemente um deficit (Verlust) científico que deverá ser suprido pelo princípio teleológico na hipótese de uma organização originária produtora do parentesco completo.

A terceira Crítica emprega expressões que sugerem as noções de autoprodução (Sie organisiert sich vielmehr selbst) e reprodução (nach einerlei Exemplar im Ganzen) ${ }^{112}$ para refletir o organismo. Os $\S \S 64$ e 65 apresentam o processo de geração como autoprodução, por causa da introdução da epigênese de Blumenbach na sua doutrina. Todavia, a doutrina que Kant utiliza nos escritos sobre as raças consiste em refletir sobre uma certa reprodução de formas, e para isso é empregado o vocabulário da conhecida doutrina moderna da pré-formação dos organismos. Ao contrário daquela, a doutrina da autoprodução aponta - dentro do

\footnotetext{
${ }^{112}$ Sie organisiert sich vielmehr selbst, und in jeder Spezies ihrer organisierten Produkte, zwar nach einerlei Exemplar im Ganzen, aber doch auch mit schicklichen Abweichungen, die die Selbsterhaltung nach den Umständen erfordert. KANT, I. Kritik der Urteilskraft, AA V: 374.
} 
amplo conceito de heautonomia da faculdade de julgar - para uma individuação orgânica, na medida em que as formas ou sistemas tornam-se particulares através da epigênese. Com a lógica da reprodução se passa o inverso, pois ela introduz formas repetidas no sistema de estruturas externas e internas do organismo, fornecendo-lhe caracteres universais empíricos. Essa forma de produção orgânica será exposta na seguinte ordem: desde a concepção kantiana de reprodução como repetição, em seguida a função da reprodução na produção do sistema da natureza, após isso, é mostrado que a causa física da reprodução são os germes, e por fim, a causalidade filosófica dos germes é a causa final.

O conceito de reprodução orgânica é próximo do de reprodução da dedução transcendental das categorias, onde Kant estabelece uma dependencia das sínteses de apreensão, reprodução e recognição, isto é, o objeto reproduzido na imaginação é determinado pelo entendimento. Kant não usa o conceito de reprodução em nenhum outro sentido que o de repetição ou o de "retornar" (zurückrufen), ou relembrar: “produção (invenção) ou reprodução (recordação)" (Production (Dichtung) oder Reproduction (Erinnerung) $)^{113}$. Kant usa a palavra reprodução num único sentido, e por isso Erzeugung tem de ser traduzido como geração, não se trata apenas de um acerto de palavras, mas de precisão na teoria.

O conceito de reprodução é central, então, para pensar o conceito de raça, pois o seu conceito depende da repetição de caracteres infalíveis que seguem a divisão da espécie, sem a repetição da divisão não se poderia “fazer nenhum conceito seguro" (keinen sicheren Begriff machen) ${ }^{114}$ de raça. A palavra reprodução ocorre apenas em três ocasiões nesses opúsculos. No primeiro deles, o Das diversas raças

\footnotetext{
${ }^{113}$ KANT, I. Metaphysik Zweiter Theil, AA XVIII: 618.

${ }^{114}$ KANT, I Bestimmung des Begriffs einer Menschenrace, . AA VIII: 92.
} 
humanas (1775), o reproduzir aparece como wieder hervorzubringen. Nesse mesmo opúsculo também se encontram as expressões "pré-determinado" (vorher bestimmt), "pré-formado" (vorgebildet) e "pré-colocado" (vorher gelegen), é evidente que se trata de um vocabulário preformacionista. A tese de Kant sobre as raças é que as cores das raças já eram pré-formadas e que elas se desenvolveram por pressão da natureza externa e se estabilizaram em quatro cores por conta de quatro grandes regiões da Terra:

Ar, sol e nutrição podem modificar um corpo animal no seu desenvolvimento, mas essa mutação não proporciona simultaneamente uma força geradora que seria capaz de se reproduzir [wieder hervorzubringen] a si mesma sem essa causa, pois o que deve se propagar, também deve ter já pré-existido na força geradora como prédeterminado a uma evolução ocasional conforme o meio ambiente no qual a criatura pode adaptar-se e no qual ela deve conservar-se constante. $^{115}$

A palavra reprodução não ocorre no segundo escrito sobre as raças, o opúsculo Determinação do conceito de raça humana (1785), mas aparece duas vezes em Sobre o uso dos princípios teleológicos em filosofia (1788). Nesse, assim como no escrito de 1775 , a reprodução não significa somente geração, mas também repetição de formas e caracteres: "Uma forma [orgânica] que na propagação é reproduzida [reproducirt] apenas esporadicamente" ${ }^{" 16}$ A terceira e última ocasião de uso da palavra se dá como "novamente reproduzido" (wieder reproducirt). O contexto em que aparece se dá na recusa de aceitar o reaparecimento de formas

\footnotetext{
${ }^{115}$ Luft, Sonne und Nahrung können einen thierischen Körper in seinem Wachsthume modificiren, aber diese Veränderung nicht zugleich mit einer zeugenden Kraft versehen, die vermögend wäre, sich selbst auch ohne diese Ursache wieder hervorzubringen; sondern was sich fortpflanzen soll, muß in der Zeugungskraft schon vorher gelegen haben, als vorher bestimmt zu einer gelegentlichen Auswickelung den Umständen gemäß, darein das Geschöpf gerathen kann, und in welchen es sich beständig erhalten soll. KANT, I. Von den verschiedenen Racen des Menschen, . AA II: 435.

${ }^{116}$ Eine Gestalt, die in der Fortpflanzung nur bisweilen den Charakter der nächsten Eltern und zwar mehrentheils nur einseitig (Vater oder Mutter nachartend) reproducirt, ist kein Merkmal, daran man den Abstamm von beiden Eltern kennen kann, z. B. den Unterschied der Blonden und Brunetten. KANT, I. Über den Gebrauch teleologischer Prinzipien in Philosophie, . AA VIII: 165.
} 
antigas, a sua hipótese é que deve estar havendo desenvolvimento completo de todos os germes: (alten Formen wieder reproducirt werden) ${ }^{117}$. O opúsculo de 1785 não usa uma única vez a palavra reprodução, mas aparece uma vez "regenerar" (wieder genesen), a qual se insere dentro da noção de reprodução. A ideia de reprodução está dentro da teoria kantiana da hereditariedade, na qual formas "herdam e transmitem" (anerbt und nachartet) em uma série que vai dos gêneros às espécies, raças, variedades, famílias e indivíduos. Kant está pensando o sistema natural pelos conceitos de sistema da lógica transcendental, isto é, os conceitos de especificação, parentesco e classificação.

Ainda no opúsculo de 1785, as formas adquiridas e que por isso são "apenas contingentemente impressas" (nur zufällig eingedrückt) no organismo não se reproduzem, pois elas não eram pré-formadas e então não pertencem ao sistema originário, pois é preciso que se manifeste como "hereditário e da natureza mesma no nascimento" 118 para que haja reprodução de formas pré-formadas no nascimento. O conceito de raça é o da reprodução dos caracteres raciais como "transmissão infalível” " (unausbleibliche Anartung): "O conceito de raça é portando o da divisão de classe de animais de um único tronco na medida em que é hereditariamente infalível" ${ }^{119} \mathrm{Na}$ história kantiana da natureza, as raças são as classes inferiores reproduzidas sob a classe da espécie, e por trás desse fenômeno está a ideia de que as partes divididas do sistema se reproduzem. As formas (os sistemas particulares na terceira Crítica) que se "transmitem infalivelmente" vêm do topo do sistema, ou do

\footnotetext{
${ }^{117}$ KANT, I. Über den Gebrauch teleologischer Prinzipien in Philosophie, . AA VIII: 176.

118 ob sie erblich und von der Natur selbst in der Geburt. KANT, I. Bestimmung des Begriffs einer Menschenrace, AA VIII: 93.

${ }^{119}$ Der Begriff einer Race ist also: der Klassenunterschied der Thiere eines und desselben Stammes, so fern er unausbleiblich erblich ist. KANT, I. Bestimmung des Begriffs einer Menschenrace, AA VIII: 92.
} 
gênero superior, e as formas que se "transmitem" falivelmente vêm de baixo, das partes particulares do sistema.

A multiplicação, propagação, ou na linguagem da primeira Crítica, a especificação, se dá pela diversidade de fins de cada espécie e variação, o que tem como fim último a conservação do sistema vivo inteiro. O "sistema natural" (Natursystem) ou "sistema físico" (physisches System) divide-se em gêneros e espécies segundo a "lei comum de propagação" (Fortpflanzung) segundo a mesma força de geração e por isso são indivíduos e classes em parentesco. Deve-se relembrar aqui que a interfertilidade é limitada ao parentesco na espécie.

Além disso, o conceito de espécie é submetido àquilo que Kant chama de "tronco" ou "fillo" (Stamm), e a articulação deste último com o das raças serve para fundamentar essa teoria da geração baseada na ideia de germe (como partícula e não como embriões de indivíduos infinitamente embutidos) e as disposições originárias. O germe é uma organização, e por isso um sistema, por exemplo, em uma das definições que lhe é dada em oposição às doenças: "Mas essas não precisam de nenhuma organização" (Aber diese bedürfen keiner Organisation). O germe é uma organização e um sistema com uma "capacidade pré-determinada" (vorher bestimmte Fähigkeit) de produzir uma adaptação ao meio-ambiente pelo desenvolvimento de uma forma cuja finalidade é conservar a vida o mais natural e o menos artificial possível. Se o meio-ambiente provoca modificação no organismo, mas essa modificação não se reproduz, então não haviam germes e disposições para ela.

Nesse capítulo, partiu-se do conceito de sistema no sentido ideal até as partes dos organismos que são os germes, os quais também são sistemas. Buscamos mostrar que a finalidade interna produzida pela ideia de sistema se dá do todo para as partes 
mínimas do organismo, portanto, desde a população de indivíduos até os tecidos e ossos dos indivíduos. O capítulo seguinte mostrará que o conceito de sistema não é suficiente, apesar de ser fundamental. 


\section{CAPÍTULO 4. Finalidade, técnica e comunidade}

Em uma Kant-Studien dos anos setenta, Antony Genova defendeu a tese de que os conceitos fundamentais para pensar o organismo seriam os de "autonomia, comunidade e reflexividade" 120 . Por sua vez, John Zammito, seguindo essa leitura, fez nela a seguinte alteração: "espontaneidade, comunidade e reflexividade"121. Um problema se põe nessa interpretação na medida em que o conceito de reciprocidade presente no $\$ 65$ da terceira Crítica é derivado primeiramente do próprio conceito de causa final, o que leva outros comentadores a uma posição oposta que nega a presença do conceito de comunidade ${ }^{122}$. Mas buscaremos mostrar que a analogia kantiana da organização político-jurídica do Estado, usada para iluminar a ideia de organismo, faz inequivocamente uso do conceito de comunidade em articulação com o de sistema. O capítulo, assim, se limita a discutir apenas os conceitos de reciprocidade e comunidade no $\$ 65$, dentro da nossa tese de que os conceitos de sistema, técnica, finalidade, liberdade e contingência são essenciais para a representação do organismo, além dos conceitos de reciprocidade e comunidade que buscamos discutir.

Antes de adentrarmos no uso kantiano desses dois conceitos, seria interessante atentarmos para o profícuo emprego que se fez na história da filosofia desde a Antiguidade até a Idade Moderna. Para isso, usamos o Historisches Wörterbuch der Biologie de Georg Toepfer, que é uma útil referência nas pesquisas históricas sobre os conceitos fundamentais da biologia. Segundo Toepfer, a palavra latina "reciprocus" significava originalmente "retornar reciprocamente ao mesmo

\footnotetext{
${ }^{120}$ (Genova, 1974)

121 (Zammito, 2003)

122 (Köchy, 2004)
} 
caminho" no sentido de um movimento de vai e vem de um corpo, como por exemplo o da água na maré. Posteriormente, ela foi transferida desse contexto físico às relações sociais e aqui significou mutualidade, permuta ou negociação entre pessoas, e aparecerá ainda em sentido biológico no século XVII. A palavra alemã "reciprocidade" (Wechselseitigkeit) será muito empregue no pensamento biológico do século 18, a sua origem é a palavra "reciprocidade" (Reziprozität) empregada por Wedel (Physiologia medica) em 1680.

Mas Toepfer acredita que o conceito já existia desde a Antiguidade. Em Hipócrates se trataria do conceito de simpatia ou compaixão entre as partes, na medida em que a medicina hipocrática entendeu a doença como desarmonia das partes. Segundo o autor ainda, a origem da reciprocidade estava antes no pensamento antigo sobre as unidades sociais que no organismo vivo mesmo, e isso já se encontrava nos pré-socráticos, e no romano Menenius Agrippa (503 a. C.). Mas também Platão, Aristóteles, Cícero, Sêneca e Marco Aurélio pensaram a essência do Estado como corpo vivo, e em todos esses autores Toepfer parece encontrar algum germe da ideia de reciprocidade. No contexto natural, além de Hipócrates, em Aristóteles haveria uma "causalidade recíproca" (allelon aitia) entre alma e corpo. Na Idade Média, Marcílio de Padua em 1324 falava em comunicação recíproca das partes (mutuo communicantibus et ad totum). Segundo Toepfer, também o mecanicismo de Descartes era pensado pela reciprocidade de todo e partes (la disposition de ses organes, que se raportent (...) tous l'un à l'autre). G. W. Wedel usa em 1680 o substantivo Reziprozität para a relação dos espíritos vitais (spiritus) e partes corporais (reciprocatio \& quidam circulus), e também de coração e artérias (perpetua est reciprocatio \& communio cordis cum arteriis). $\mathrm{O}$ autor indica ainda que Berkeley atribui o conceito de reciprocidade à Hipócrates: "Em tal 
reciprocidade, Hipócrates supôs a maneira de agir da natureza”. Charles Bonnet, o leibniziano que teria levado a scala naturae às últimas consequências, também fez uso do conceito de reciprocidade para pensar o organismo, o que também se encontrará em Hegel.

Segundo Toepfer, o conceito de reciprocidade no contexto do organismo em Kant teria se originado de Boerhaave através de seus alunos M. E. Boretius e J. C. Bohlius que lecionaram a fisiologia de Boerhaave em Königsberg à época de Kant nos cursos de Medicina (Physiologiam ad Boerhavium). Após Kant, o conceito ainda foi usado por Xavier Bichat em 1801 como "comunicação" e "consenso" (Tous les médecins ont connu le consensus singulier que existe entre tous nos organes) e simpatia entre as partes do organismo. Também Lamarck e Barthez da biologia, e os filósofos Fichte, Schelling e Hegel empregaram tal conceito. O enorme verbete Wechselseitgkeit $^{123}$ do Dicionário Histórico de Biologia de Georg Toepfer é excepcional. Toepfer acredita que Wechselwirkung é completamente diferente de Wechselseitigkeit, o primeiro diria respeito a categoria apenas, mas o autor não faz maiores explicações a não ser alegar o estatuto constitutivo do primeiro.

\subsection{A finalidade interna assentada na reciprocidade}

O nosso texto visa tão somente reconhecer, mas não explorar exaustivamente o modo como Kant poderia ter pensado a reciprocidade no organismo, o que demandaria um estudo das fisiologias de Blumenbach e Boerhaave. Kant emprega uma série de conceitos a priori na ideia de organismo, como os de sistema, comunidade, liberdade, finalidade, técnica e contingência. $O$ conceito de comunidade

${ }^{123}$ (Toepfer, 2011, p. $738-763$ ) 
é fundamental para pensar a epigênese, sobretudo, a epigênese vegetal. Comentadores como Rachel Zuckert e Jennifer Mensch acreditam que o conceito de sistema seria suficiente para pensar o organismo. Ora, mas em nenhuma das definições de sistema que Kant nos apresenta na primeira ou na terceira Crítica o conceito de reciprocidade tomou parte de modo explícito da definição: o todo estruturador das partes; a convergência das partes ao foco imaginário; o sistema como subordinação de classes sob classes em unidade, parentesco e espécie. Kant chega muito perto de introduzir alguma noção de reciprocidade nas definições de sistema da primeira Critica, por exemplo, no Apêndice à Dialética Transcendental, onde é afirmado que o todo deve "determinar a priori para cada parte o seu lugar e relação às restantes" (jedem Teile seine Stelle und Verhältnis zu den übrigen a priori zu bestimmen - A645/B673), e na Arquitetônica onde é afirmado que o todo deve determinar "o lugar das partes entre si" (die Stelle der Teile untereinander A832/B860), pois aí está envolvida a ideia de que em um edifício absolutamente todas as partes devem se conectar e possuir fins e aplicações. Kant está aí muito próximo da arquitetônica de Lambert, autor que se dedicou muito mais que aquele a uma espécie de teoria dos sistemas, Kant porém se dedicou mais ao problema da filosofia como sistema.

Como se vê, Kant pensa as partes do sistema como tendo relação a todas as outras partes, de modo muito semelhante à reciprocidade entre as partes, todavia nesse caso ainda produzidas pelo todo. A terceira Critica terá como novidade a produção do todo pela comunidade das partes. A rigor, se deveria derivar o conceito de reciprocidade da terceira categoria de relação, e, por sua vez, da disjunção lógica pensada pelo entendimento como comunidade e reciprocidade por conta da coordenação entre as partes e não da disjunção lógica tomada pela razão na ideia de 
sistema, a qual implica em subordinação entre as partes. Comunidade e reciprocidade então aparecem juntas na Analítica da primeira Crítica, pois se originam em torno da disjunção, então, por que estariam separadas na terceira Crítica?

Na lógica geral, Kant afirma que o juízo disjuntivo assenta, além de na extensão e no conteúdo, sobretudo na exclusão dos membros, como na operação lógica atualmente considerada como 'ou exclusivo' ${ }^{124}$. Ao que parece, a mesma atitude do entendimento na divisão lógica é posta em prática no pensamento da divisão das coisas, onde o entendimento pensa as partes das coisas excluindo-se mutuamente, e daí a categoria de reciprocidade, que se produz no ato do entendimento de ontologizar, isto é, considerar como coisas os membros excludentes da disjunção, e assim tais membros são tomados como em comunicação, comunidade ou reciprocidade, por conta da exclusão e da extensão na mesma esfera:

O mesmo procedimento do entendimento quando representa a esfera de um conceito dividido, ele considera também se pensa uma coisa como divisível, e, como os membros da divisão no primeiro caso excluem-se entre si e ainda em uma esfera estão conectados, assim ele representa para si as partes do último enquanto tal - cuja existência (como substâncias) cada uma compete excluindo-se das restantes ainda como ligadas em um todo. ${ }^{125}$

A reciprocidade está, assim, primeiramente associada ao procedimento lógico de exclusão na operação lógica de disjunção, pois na medida em que os membros se excluem mutuamente são pensados em reciprocidade. Essa mesma operação de exclusão pode ser vista na passagem da Metafísica dos Costumes que tomamos como chave para compreender a nota de rodapé do $\$ 65$, mas também no antagonismo da sociável insociabilidade. Na Metafísica dos Costumes, Kant afirma que pessoas ou

\footnotetext{
${ }^{124}$ (Longuenesse, 2011, p. 24)

125 Kant, I. KrV, B113.
} 
grupos em influência recíproca uns contra os outros (im wechselseitigen Einflusse gegen einander) necessitam de leis. Neste caso, se trata da ideia de uma comunidade de oposição das partes, e Kant assume que emprega o conceito de comunidade na sua filosofia do direito e do social, mas em sua filosofia do organismo o conceito é introduzido lateralmente, através de uma nota de rodapé muito negligenciada pelos comentadores.

A possibilidade de pensar o "fim natural" exige os conceitos de comunidade e sistema, pois na medida em que a natureza é autoprodutora surge então a necessidade de introduzir os conceitos de causa de si, espontaneidade e liberdade, e tal autoprodução será pensada por Kant em duas operações de reciprocidade. Primeiramente, na ordem de introdução do conceito, se trata da produção recíproca entre o todo e as partes. Ora, a possibilidade de pensar essa reciprocidade exige a independência das partes em relação ao todo (para que este seja efeito das partes) e consequentemente a produção recíproca das partes, como se elas não dependessem do todo, elas então têm de poder ser pensadas como ideia como se fossem produzidas por interação. A estrutura argumentativa é então como se segue:

1. o todo deve ser a causa das partes (Kunstprodukt)

2. as partes devem ser a causa recíproca de si mesmas

3. as partes devem ser a causa do todo

Logo, o todo e as partes são reciprocamente causa e efeito (Naturprodukt)

Ora, o exemplo imediato dessa reciprocidade encontra-se nos fins materiais, no 'prático (da arte)', no exemplo onde o lucro é causa da casa e esta é causa do lucro. Trata-se da finalidade material como no momento lógico da relação na 
analítica do belo, a matéria da causa final (o fim propriamente dito), e não apenas a forma de finalidade (o simples caráter de conformidade a fins de algo). A casa deveria ser pensada como meio para a obtenção do fim que é o lucro, mas o meio tem de estar de tal maneira contido na causa final que ele se torna simultaneamente fim. Kant transporta essa reciprocidade teleológica para o pensamento do objeto segundo os conceitos de todo e partes. Como é possível uma tal reciprocidade final entre todo e partes necessária à autoprodução do organismo?

A possibilidade de pensar o organismo pela própria natureza e não por uma técnica extra mundana, isto é, por uma produção autônoma da natureza, exige uma ideia de causa final pensada primeiramente por um certo conceito de reciprocidade, e em segundo lugar, um conceito ausente, mas em parte sugerido, de comunidade, o qual será discutido a frente. Deste modo, dentre os passos da argumentação kantiana, nós destacamos então os enunciados: no §64, "é causa e efeito de si mesmo" (von sich selbst Ursache und Wirkung ist); e no §65, "para si mesmo reciprocamente como causa e efeito" (zu sich selbst wechselseitig als Ursache und Wirkung). A mudança se dá, como é evidente, na introdução do conceito de "reciprocidade" (wechselseitig) para pensar a autoprodução. Kant afirma que "nós encontramos" uma tal reciprocidade no "prático (nomeadamente da arte)" (Praktischen (nämlich der Kunst)). Tal modelo de causa final estabelece primeiramente uma reciprocidade entre produto e produtor, isto é, uma reciprocidade pelo rendimento como causa e efeito da casa, há assim uma finalidade recíproca. A reciprocidade é uma característica inerente à técnica na medida em que os artefatos são produzidos tendo em vista uma retorno útil ao produtor.

Kant então aplica esse outro modelo ao organismo, diferente do modelo da primeira Crítica no qual as partes eram produzidas pelo todo em uma única direção. 
O resultado é que se pode pensar o organismo como produção recíproca entre o todo e as partes: "Pois só de tal modo é possível que inversamente (reciprocamente) a ideia do todo determine por isso a forma e a ligação de todas as partes." ${ }^{126}$ Assim, será da aplicação da ideia de finalidade recíproca às partes que Kant introduzirá implicitamente via analogia o conceito de comunidade.

A partir da composição da causalidade que vai do todo para as partes (sistema) e da causalidade que vai da comunidade das partes para o todo, Kant alcança a reciprocidade teleológica que ele havia definido no início do $\$ 65$. O organismo ganha então a sua "derivação de um conceito determinado" a partir da mesma reciprocidade entre todo e partes que havia no modelo do prático da técnica da construção da casa em vista do rendimento financeiro.

Quanto à possibilidade de derivar reciprocidade de sistema, se bem que a ideia de sistema também tenha origem na disjunção, e segundo Köchy, reciprocidade tenha feito parte do conceito de sistema após Kant no século XIX, em Kielmeyer, por exemplo, e por isso se poderia pensar que Kant estaria ampliando o conceito de sistema através do conceito de reciprocidade, isso com o objetivo de pensar o sistema orgânico, essa hipótese todavia deve ser tomada com cautela, pois Kant geralmente enfatiza, na ideia de sistema, a subordinação entre todo e partes ou entre gênero e espécie e muito pouco a coordenação entre as partes, a qual é necessária para a reciprocidade ou comunidade. Se em Kant não está claro se sistema deve possuir os conceitos de subordinação e coordenação, em Lambert isso é assumido explicitamente, mas ainda não sabemos se Kant leu o seu Fragment einer Systematologie (1767 1771), ou se a própria Arquitetônica lambertiana já continha essas idéias:

${ }^{126}$ (Kant, KU, AA V: 373) 
§40. Um sistema deve em geral ser adequado não apenas em si, mas também em cada parte nas suas intenções particulares, por isso se deixa pensar facilmente uma diferença entre a intenção do sistema todo e as intenções de cada parte do mesmo. Igualmente se faz concebível que as intenções das partes são tanto coordenadas (zusammen geordnet) como subordinadas (untergeordnet) entre si, e daí são por um lado recíprocas e por outro estão em dependência unilateral. ${ }^{127}$

De qualquer forma, ainda que a coordenação entre as partes também exista na idéia kantiana de sistema, como sugerimos acima, ainda assim a afirmação de Kant no $§ 65$ de que a unidade sistemática não deve ser tomada como causa porque isso constituiria um "produto da arte" e não um "produto da natureza", e junto a isso a própria analogia político-jurídica, nos obrigam a admitir essa reciprocidade como ligada ao conceito de comunidade e finalidade.

127 (Lambert, 1784, p. 409) 


\subsection{Finalidade interna assentada na comunidade}

Quanto ao conceito de comunidade, então, o essencial consiste em pensar que o julgamento de uma coisa como fim natural deve responder às condições anteriormente expostas sobre o todo e as partes. A primeira é que o todo seja causa 
das partes, pois respondendo a essa exigência, a coisa pode ser julgada como teleológica e produto de uma técnica. Ora, a segunda condição (zweitens dazu erfordert), exigida para que se pense o organismo como produto da natureza, é que a finalidade seja produzida das partes para o todo. O tipo de totalidade que se constitui a partir do múltiplo, Kant a nomeia comunidade, e é com uma interpretação do conceito de comunidade que lidamos agora. Essa linha interpretativa remonta a Hegel, e posteriormente foi defendida por Philonenko, Genova e Zammito. A nossa posição é que se Kant emprega o sentido prático de comunidade, e não apenas o sentido teórico da terceira analogia da experiência, então, não é impossível que ele também empregue o conceito de comunidade no campo intermediário que se constitui a terceira Crítica. Segundo Zammito:

Arthur Genova identifica três elementos cruciais no conceito de epigênese em sua forma acabada no século XVIII: autonomia, comunidade e reflexividade. Nos meus termos, eu gostaria de ressaltar a radicalidade da emergência substituindo autonomia por espontaneidade. Por comunidade Genova entende a mutualidade de causa e efeito e de partes e todo que é central à noção de forma orgânica, especialmente como Kant articulou-a. ${ }^{128}$

Na sua interpretação do conceito kantiano de organismo, Alexis Philonenko acentua o $\S 64$, e sobretudo a autoprodução das partes na epigênese vegetal. Para Philonenko, Kant estaria lidando com a clássica questão da scala naturae, na medida em que o reino vegetal seria o intermediário entre o reino mineral mecânico e o reino animal, Kant assim teria começado pelo vegetal como primeira oposição ao mecanismo da natureza e a passagem desse ao organismo. Além disso, a planta seria

128 Zammito, J. (2007) "Kant's Persistent Ambivalence toward Epigenesis, 1764-90" in Understanding Purpose: Kant and the Philosophy of Biology, Edited by Philippe Huneman, New York: University of Rochester Press. p. 54. 
uma comunidade, porque haveria nela possibilidade quase infinita de enxerto, enquanto que nos animais o enxerto seria extremamente limitado, pelo menos pela "autoajuda da natureza" (Selbsthülfe der Natur):

a árvore nos põe em presença de uma relação dinâmica, tanto mais interessante na medida em que a árvore é uma totalidade e não uma unidade. Essa totalidade evoca a noção de comunidade humana onde cada um serve a cada um sem deixar de ser um indivíduo ${ }^{129}$

Philonenko distingue essa forte unidade na organização animal, e apesar de o autor não ter apercebido, se trata da ideia de sistema. E as plantas poderiam ser tomadas por este motivo pela categoria de comunidade. A comunidade também caracteriza a capacidade de adaptação dos organismos ao meio, é nesse sentido que Philonenko afirma que as plantas evocam "o movimento e a dialética da comunidade humana", possivelmente pelo componente de conflito e exclusão mútua que há na comunidade e no antagonismo social, e que Kant transforma em "colaboração" (Mitwirkung) pela introdução da finalidade recíproca:

É suficiente observar que no texto do $\$ 65$ Kant fala de força formadora (bildende Kraft) e que na nota ele fala de transformação (Umbildung). A grande novidade fichteana está na redefinição da propriedade e na reflexão sobre o trabalho. Como foi dito no $\$ 2$, o ser organizado - a árvore descrita por Kant - evoca o movimento e a dialética da comunidade humana. ${ }^{130}$

A "transformação de um grande povo em um Estado" refere-se, assim, ao processo de auto-organização de um Estado. Vejamos como povo e Estado estão presentes na filosofia prática de Kant. No $§ 90$ da terceira Crítica, Kant discute o argumento moral

${ }^{129}$ PHILONENKO, A. "Kant et la philosophie biologique”, in Études Kantiennes, p. 121.
${ }^{130}$ PHILONENKO, A. "Kant et la philosophie biologique", in Études Kantiennes, p. 122. 
da existência de deus oriundo da segunda Crítica - dado que a teleologia da terceira proporciona tão-somente a sua "confirmação desejada" - e para tal o estatuto da analogia é passado em revista, dado que a analogia transfere determinações entre objetos e conceitos distintos, tal transferência tem de ser sempre limitada. O exemplo dado é o da analogia do conceito teórico de comunidade ao campo prático:

Assim, segundo a analogia com a lei de igualdade de ação e reação na atração e repulsão dos corpos entre si, também posso pensar a comunidade de membros de um ser comum segundo regras do direito, mas não transferir aquelas determinações específicas (a atração ou repulsão material) a essas regras e aplicar aquelas determinações aos cidadãos para constituir um sistema que se chama Estado. ${ }^{131}$

Essa transferência do conceito de comunidade ao domínio prático se encontra na Metafísica dos Costumes. A primeira parte da Doutrina do Direito, o direito privado, traz uma série de ocorrências do conceito de comunidade, Kant fala em coexistência de liberdades e na "posse comum" do solo como "comunidade originária", a comunidade de posse. Não é o caso de desenvolver exaustivamente o assunto aqui, mas a segunda parte, o direito público, começa pensando-o pela ideia de sistema. $\mathrm{O}$ $\S 43$ da Metafísica dos Costumes começa com um trabalho de justificação do direito público. Ao que parece, o argumento do ponto de vista jurídico é o de que pessoas ou povos em "influência recíproca" (comunidade) "necessitam" (bedürfen) de direito público (sistema):

O conjunto de leis que necessitam de uma proclamação universal para produzir um estado jurídico é o direito público. Esse é, portanto, um sistema de leis para um povo, isto é, para uma multidão de homens, ou para uma multidão de povos, os quais, se estão uns contra os outros em influência recíproca, necessitam do estado jurídico no qual eles se

131 Kant, I. KU, AA V: 465. 
submetem a uma vontade unificadora, uma constituição (constitutio), de tal modo que o jurídico torne-se compartilhado. ${ }^{132}$

Do ponto de vista da lógica transcendental, o que está por trás é portanto a articulação entre comunidade e sistema, na medida em que uma comunidade de pessoas ou de povos necessitam de um sistema de leis político-jurídicas. Esse emprego da categoria de comunidade na filosofia política de Kant está completamente de acordo com o seu uso transcendental na terceira analogia da experiência. A comunidade de substâncias significa que elas ocupam o mesmo tempo e espaço e exatamente por isso estão em influência recíproca, comércio, contato, reciprocidade etc. Trata-se de duas espécies de comunidade que constituem uma. A primeira é a comunidade temporal fundada na percepção da duração das substâncias. Kant exemplifica com o seu argumento de que se passamos da percepção da Lua a Terra continuamente e inversamente, e se elas continuam a durar no tempo, então elas existem no mesmo tempo. A comunidade espacial é baseada na impossibilidade de percepção do espaço vazio, se não há espaço vazio entre as substâncias então elas estão no mesmo espaço, em contato e portanto em influência recíproca. Por isso, uma comunidade espaço temporal de substâncias. O direito privado parte da ideia de indivíduos que vivem no mesmo espaço, a "comunidade originária" da Terra, e por isso estão em reciprocidade e daí a necessidade de um direito privado para que não se confunda o "meu e o teu". Nós buscamos então apresentar esses pontos: 1. que os conceitos de comunidade e sistema estão presentes na doutrina do direito de modo a

\footnotetext{
${ }^{132}$ (Der Inbegriff der Gesetze, die einer allgemeinen Bekanntmachung bedürfen, um einen rechtlichen Zustand hervorzubringen, ist das öffentliche Recht. - Dieses ist also ein System von Gesetzen für ein Volk, d. i. eine Menge von Menschen, oder für eine Menge von Völkern, die, im wechselseitigen Einflusse gegen einander stehend, des rechtlichen Zustandes unter einem sie vereinigenden Willen, einer Verfassung (constitutio), bedürfen, um dessen, was Rechtens ist, theilhaftig zu werden). (Kant, MS, AA VI: 337.) Traduzimos Menge por multidão seguindo a tradução de G. Lebrun em Kant e $o$ fim da metafísica de um outro texto de Kant que não a Metafísica dos Costumes, nos pareceu fazer mais sentido pensar comunidade por multidão antes que por quantidade ou número.
} 
dar uma unidade complexa entre povo e Estado; 2. que comunidade e sistema estão presentes na nota de rodapé que reproduzimos abaixo completamente, na qual Kant afirma que a "transformação de um grande povo em um Estado" é uma analogia que “pode dar luz" aos fins naturais através de uma "certa ligação" encontrada no organismo estatal:

Pode-se, inversamente, dar luz a partir de uma certa ligação que todavia é encontrada também mais na ideia que na realidade através de uma analogia com os imediatamente nomeados fins naturais. Assim, tem-se servido muito adequadamente da palavra organização em uma recentemente empreendida transformação completa de um grande povo em um Estado na instituição de magistraturas etc e mesmo para o completo corpo do Estado. Pois cada membro deve ser em verdade em tal todo não apenas meio, mas simultaneamente também fim, na medida em que colabora para a possibilidade do todo, e a ideia do todo é determinada por conta do lugar e função de cada parte. ${ }^{133}$

A comunidade no organismo se limita a três passagens da Analítica do juízo teleológico: a autoprodução das partes no §64, importante para a concepção hegeliana do vegetal (“as partes, que existem como indivíduos": Enzyklopädie, §349); a produção recíproca das partes no §65; e a definição de orgão, não como instrumento, mas como “orgão produtor" em reciprocidade ainda no §65. De modo distinto ao parentesco, que produz as partes por divisão do sistema, a produção por comunidade se dá por reciprocidade. Com isso, não se nega o parentesco, mas apenas se integra ao fio condutor do sistema, o qual vai do todo para as partes, o sentido

\footnotetext{
${ }^{133}$ Man kann umgekehrt einer gewissen Verbindung, die aber auch mehr in der Idee als in der Wirklichkeit angetroffen wird, durch eine Analogie mit den genannten unmittelbaren Naturzwecken Licht geben. So hat man sich bei einer neuerlich unternommenen gänzlichen Umbildung eines großen Volks zu einem Staat des Worts Organisation häufig für Einrichtung der Magistraturen usw. und selbst des ganzen Staatskörpers sehr schicklich bedient. Denn jedes Glied soll freilich in einem solchen Ganzen nicht bloß Mittel, sondern zugleich auch Zweck und, indem es zu der Möglichkeit des Ganzen mitwirkt, durch die Idee des Ganzen wiederum seiner Stelle und Function nach bestimmt sein. (Kant, KdU, AA 05: 375)
} 
oposto, da comunidade, das partes ao todo. Comunidade é contato por conta de coexistência, isto é, compartilhar o mesmo espaço. Ora, o objeto natural é refletido pela unidade técnica na medida em que possui uma forma, mas a forma técnica é produto das partes, enquanto a forma sistemática é produto do todo sobre as partes.

É muito provável que a unidade distributiva e a comunidade não exijam uma forma especial nos objetos, mas apenas contato entre as partes, por isso nesse sentido não constituiriam um sistema, as comunidades são sem forma, mero agregado, mas suas partes estão ao menos em causalidade recíproca. Portanto, quando Kant afirma que as partes têm de produzir reciprocamente umas às outras, isso só parece ser possível se comunidade e técnica estiverem presentes simultaneamente na representação do organismo, de tal modo que a produção da forma pela técnica da natureza ocorra pela heautonomia das partes: "as partes do mesmo liguem-se assim para a unidade de um todo de tal modo que elas sejam umas das outras causa e efeito recíprocos da sua forma." (Kant, KU, V: 373). Constitui-se assim uma outra teleologia pela ideia de uma autoprodução das partes onde cada parte é fim. Kant está pensando segundo uma analogia política onde cada membro é fim e colabora ou concorre (Mitwirkung) na produção do Estado.

A maior parte dos comentadores têm negligenciado a nota de rodapé que nos baseamos para introduzir o conceito de comunidade. No livro Kant's Theory of Biology, nenhum dos artigos aborda a analogia política do $§ 65$, e mencionamos aqui apenas de passagem três, os de Luca Illeterati, Angela Breitenbach e Ina Goy, pois esses três abordam as analogias desse parágrafo, mas excluem de seus estudos a analogia político-jurídica da nota de rodapé. Por sua vez, Angela Breitenbach, em seu livro Die Analogie von Vernunft und Natur: Eine Umweltphilosophie nach Kant, faz um longo estudo sobre as analogias do organismo. A autora passa pela crítica de 
Kant à prova analógica no $\$ 90$ da terceira Crítica, e segundo nosso ponto de vista, a autora não compreendeu o argumento de Kant (Breitenbach, 2009, p. 74). A ideia central ali é a de limitar a analogia, assim, o que Kant está proibindo de se transferir do físico para o político jurídico é justamente o que ela está transportando, ou seja, a atração e repulsão recíprocas, o que se está autorizando é a transferência do conceito de comunidade para o sistema jurídico. Além disso, a autora analisa essa analogia do $\S 90$, mas não a conecta com a analogia política da nota do $\S 65$. Breitenbach ainda faz uma pequena discussão onde ela critica o ponto de vista de Georg Sans, autor que também parece defender o conceito de comunidade na ideia de organismo (Breitenbach, 2009, p. 107). Segundo a autora, como a finalidade não poderia ser conhecida categorialmente, mas apenas analogicamente, não poderia haver uma categoria como a de comunidade no organismo, mas, como mostramos, a comunidade é introduzida através da analogia político-jurídica, a qual é posta de lado pela grande maioria dos comentadores.

Como conclusão, no $§ 65$ Kant emprega a palavra "desvio" para se referir a certos efeitos da autoprodução. Ao que parece, a epigênese proporcionaria também alguma espécie de desvio adequado à adaptação ao meio. Tendo empregado a palavra "desvio" (Abweichung) nas duas partes da sua filosofia, na teórica ela significa desvio de direção, e alguns comentadores remontam ao conceito de clinamen, e na filosofia prática, os desvios morais. A enciclopédia de Zedler traz o seguinte: “Anomalia é a declinação de uma palavra em seu acidente da regra comum ou paradigma."134 O desvio significa no organismo uma pequena liberdade absolutamente necessária à autoconservação. A epigênese é, assim, a produção do

\footnotetext{
${ }^{134}$ (Zedler, 1732, p. 1581.) (Anomalia ist die Abweichung eines Worts in seinen Accidentibus von den gemeinen Regeln oder Paradigmatibus.)
} 
particular segundo a heautonomia da faculdade de julgar fundada na lei da especificação da natureza. $\mathrm{O}$ organismo encontra uma pequena liberdade de se desviar do padrão. Ao contrário, a pré-formação é a reprodução do universal, e, é isso que se intenta mostrar, tudo isso ocorre em simultaneidade, ou seja, na medida em que a heautonomia das partes em comunidade recíproca produzem um todo e esse todo retorna como causa das partes subordinadas ao sistema o organismo é simultaneamente comunidade, técnica e sistema. Portanto, a recirocidade oriunda da finalidade, segundo a analogia com o 'prático da arte', está em ligação com a comunidade das partes, segundo a analogia política da auto-organização do Estado.

\section{CONCLUSÃO:}

A tese buscou resolver uma série de impasses entre os comentadores da teoria kantiana do organismo, os quais tendem a acentuar demasiadamente um conceito ou outro, e acabam pecando em análise. Para isso, buscamos uma posição que articulasse a totalidade dos conceitos envolvidos no pensamento sobre o organismo. Tal posição consistiu em tomar o fio condutor da produção da finalidade interna que define o organismo pelos processos de epigênese e pré-formação. Atualmente, três comentadores têm posições significativas em relação a epigênese e pré-formação. Para John H. Zammito - o autor mais citado sobre o objeto em questão e o que mais 
se aproxima da verdade - epigênese e pré-formação estão sendo articuladas na filosofia kantiana: "eu defendo que Kant nunca foi completamente um epigeneticista porque ele temia suas implicações materialistas" ${ }^{\text {"135 }}$

Um segundo autor bastante importante aqui é Peter McLaughlin ${ }^{136}$, o qual alinha Kant aos teóricos da epigênese, mas explica a concepção kantiana de epigênese a partir da ideia de reprodução, seguindo uma terminologia de época originada a partir de Buffon. Segundo McLaughlin, o primeiro a empregar sistematicamente o conceito de reprodução foi Buffon $^{137}$. Mas se trata de outro problema em Kant, pois Buffon tem uma teoria materialista da geração, e ela tem de responder ao problema da reprodução. Mas Kant tem uma teoria teleológica, e a reprodução não é o seu problema, mas sim o da naturalização da teleologia. O autor faz um uso mais fraco da ideia de reprodução, ele a toma como questão geral da biologia: "Na Analítica, Kant procura derivar as consequências metodológicas da introdução na biologia de um conceito geral de reprodução de um sistema orgânico pela introdução do conceito de finalidade objetiva."138 Mas o paradigma kantiano, como nós mostramos em nossa tese, não é apenas o da reprodução, mas também o da autoprodução. Peter McLaughlin chega mesmo a usar a expressão "auto-reprodução"

\footnotetext{
${ }^{135}$ ZAMMITO, J. "Epigenesis in Kant: Recent reconsiderations" in Studies in History and Philosophy of Science 58 (2016), p. 85.

${ }_{136}$ McLAughlin, P. Kant's Critique of Teleology in Biological Explanation: Antinomy and Teleology.

137 'The term 'reproduction' was introduced in the early 18th century to denote the regeneration of lost or mutilated organs in the salamander and other amphibians and retained this meaning up to the beginning of the 19th century. It was apparently Buffon who first extended the meaning to include propagation as well. For Buffon "reproduction" was the most general common trait of animals and plants. In the second volume of his Histoire naturelle after a discussion of the commonalities of animal and vegetable kingdoms (Chapt. 1), he takes up "Reproduction en générale" (Chapt. 2) before he turns to the particular kinds of reproduction: "De la nutrition \& de developpement" (Chapt. 3) and "De la génération" (Chapt. 4). His point of departure for the entire discussion is of course the regenerative capacities of the polyp." MCLAUGHLIN, P. Kant's Critique of Teleology in Biological Explanation: Antinomy and Teleology, p. 19

${ }_{138}$ McLAUGHLin, P. Kant's Critique of Teleology in Biological Explanation: Antinomy and Teleology, p. 40.
} 
(self-reproduction), o que é sinal de um efetivo problema de interpretação do texto kantiano.

Tobias Cheung toma o caminho inverso acentuando o preformacionismo ${ }^{139}$. Apesar de o autor deixar claro que Kant rejeitava a "preformação individual", a sua interpretação não é segura, a palavra epigênese não aparece uma única vez em seu texto. Cheung está seguindo e acentuando a interpretação de McLaughlin, autor que interpretou a Analítica pelo conceito de reprodução ${ }^{140}$. Segundo Cheung:

Kant nomeia esse modo de reprodução posteriormente de propagação (Fortpflanzung). Como primeira característica do corpo organizado, ela introduz a problemática central dos seus fenômenos, isto é, a reprodução contínua de uma forma de ordenação nos indivíduos através dos indivíduos mesmos. Nessa perspectiva, para Kant, a árvore existe sempre como árvore na árvore. Ela é como corpo organizado um corpo reprodutivo. Isso o que nela é organizante, é reprodutivo, e isso o que nela é organizado, é condição da capacidade para reprodução. ${ }^{141}$

Como se vê, trata-se de uma interpretação exclusivamente preformacionista, e, segundo a tese que apresentamos, uma posição incorreta. A maneira correta de interpretar a ideia kantiana de organismo é pela conciliação das duas teorias embriológicas, e pela articulação de conceitos a priori provenientes das três

\footnotetext{
${ }^{139}$ CHEUNG, T. "Der Baum im Baum: Modellkörper, reproduktive Systeme und die Differenz zwischen Lebendigen und Unlebendigen bei Kant und Bonnet.” In E.-O. Onnasch (Ed.), Kants Philosophie der Natur: ihre Entwicklung im 'Opus postumum' und ihre Wirkung (pp. 25-49). Berlin, de Gruyter.

${ }^{140}$ Cf. a nota da página 31, onde Cheung indica o seu débito com McLaughlin, mas também o seu desconhecimento de que a palavra Reproduktion nunca teria sido usada em contexto biológico por Kant, mas apenas para a sua teoria da imaginação: "Para a interpretação das três características como modos de reprodução ver também McLaughlin 1989, 43. Kant utiliza a expressão 'reprodução' apenas em um lugar na primeira parte da Crítica do Juízo (KdU §59, AA 5.352), para rejeitar uma "lei da associação da imaginação' (...)" CHEUNG, T. "Der Baum im Baum.” p. 31. Também nos cursos de metafísica a palavra reprodução é reservada à imaginação: "Experiência é conhecimento de objetos que estão presentes nos sentidos. Imaginação é intuição também sem presença do objeto, e essa intuição chama-se objeto, então, um fantasma, o qual pode ser uma produção (invenção) ou reprodução (memória) de uma intuição tida anteriormente." (Erfahrung ist Erkentnis der Gegenstände, die den Sinnen gegenwartig sind. Einbildung ist Anschauung auch ohne Gegenwart des Gegenstandes, und diese Ansch das Object heißt alsdann ein Phantasma, welches eine Production (Dichtung) oder Reproduction (Erinnerung) einer Vorher gehabten Anschauung seyn kann.) KANT, I. AA XVIII, Metaphysik Zweiter Theil, 618.

${ }^{141}$ CHEUNG, T. "Der Baum im Baum." p. 32.
} 
faculdades superiores de conhecimento. É o caso, por exemplo, da interpretação que reduz o organismo à sistema. A ideia de sistema não é idêntica à de finalidade, é preciso preservar a independência da ideia de sistema para que faça sentido, por exemplo, a possibilidade de pensar a gravidade apenas pela ideia de sistema independentemente de finalidade. Daí que reduzir a ideia de organismo à de sistema sem introduzir o conceito de fim e o de divisão e distribuição é uma explicação incompleta. O mesmo vale para o conceito de técnica, o qual deve ser pensado em oposição ao de sistema, como um procedimento que procede de modo inverso ao da divisão, ele é a busca por uma unidade indeterminada, a qual serve como base conceitual para a epigênese. Portanto, uma interpretação que amplie o número de conceitos de reflexão do organismo é preferível àquelas que busquem reduzí-lo a um único conceito essencial.

\section{BIBLIOGRAFIA:}

I. Bibliografia primária

KANT, I. Kritik der Urteilskraft, Suhrkamp, Frankfurt am Main, 1997. . Kritik der reinen Vernunft, Suhrkamp, Frankfurt am Main, 1997. . Metaphysische Anfangsgründe der Naturwissenschaft, Meiner Verlag, Hamburg, 1997. Opus postumum Akademie-Ausgabe, Vol. 21 e 22, Berlin Walter de Gruyter, 1968.

. "Berliner Physik" e "Danziger Physik", Akademie-Ausgabe, Vol. 29, Berlin Walter de Gruyter, 1968. 
Reflexionen zur Physik und Chemie, Akademie-Ausgabe, Vol. 14, Berlin

Walter de Gruyter, 1968.

. Vorlesungen über Metaphysik und Rationaltheologie, Akademie-Ausgabe,

Vol. 28, 2,1, e Vol. 28, 2,2, Berlin Walter de Gruyter, 1968.

BAUMGARTEN, A. G. Metaphysik, trad. do latim G. F. Meier, Dietrich Scheglmann, Jena, 2004.

Philosophia Generalis, Olms Verlag, Hildesheim, 2002.

WOLFF, C. Einleitende Abhandlung über Philosophie im allgemeinen, trad. G.

Gawlick e L. Kreimendahl, Frommann Holzboog Verlag, Stuttgart, 2006.

II. Bibliografia secundária

ADICKES, E. Kant als Naturforscher. BD. I e II, Walter de Gruyter, Berlin, 1924.

ALLISON, H. “Kant's Antinomy of Teleological Judgment”. In: Guyer, Paul (ed.): Kant's Critique of the Power of Judgment. Lanham, MD. 2003. . Essays on Kant, Oxford University Press, 2012.

BACIN, S; FERRARIN, A; La ROCCA, C e RUFFING, M. (eds.) Kant und die Philosophie in weltbürgerlicher Absicht, Akten des XI. Internationalen KantKongresses. I-V-Walter de Gruyter, 201

Balan, Bernard, "Anatomy" in Encyclopedia of the Enlightment ed. Michel Delon, Vol. I, Routledge, London, 2013.

BARTLETT, S. J e SUBER, P. Self-Reference: Reflections on Reflexivity. MARTINUS NIJHOFF PUBLISHERS, DORDRECHT, BOSTON, LANCASTER, 1987. 
BERG, H. Kant on Proper Science: Biology in the Critical Philosophy and the Opus Postumum, Vrije Universiteit, 2011.

BREITENBACH, A. "Two views on nature: A solution to Kant's antinomy of mechanism and teleology", British Journal for the History of Philosophy, 16:2, $351-369$.

Die Analogie von Vernunft und Natur, de Gruyter

BAEUMLER, A. Das Irrationalitätsproblem in der Ästhetik und Logik des 18. Jahrhunderts bis zur Kritik der Urteilskraft, Max Niemeyer, Tübingen, 1967.

BAUER-DREVERMANN, I. "Der Begriff der Zufälligkeit in der Kritik der Urteilskraft." In: Kantstudien 56, S. 497-504. 1965

BREIDENBACH, O. "Die Geburt des Lebendigen Embryogenese der Formen oder Embryologie der Natur?-Anmerkungen zum Bezug von Embryologie und Organismustheorien vor 1800." in Biologisches Zentralblatt, 114, 191-199, 1995.

BODEMER, C. "Regeneration and the decline of preformationism in eighteenthcentury embryology". in Bulletin of the History of Medicine, 38, 20-31, 1964.

BOMMERSHEIM, Paul, "Der vierfache Sinn der inneren Zweckmäßigkeit in Kants Philosophie des Organischen.” Kant-Studien, Issue 1-3 (November 2009). Pages 290-309.

. "Der Begriff der organischen Selbstregulation in Kants Kritik der Urteilskraft." In: Kantstudien 23, S. 209-220. 1919

BUSCHE, H. "Kants Deduktion des Zweckmäßigkeitsprinzips aus der reflektierenden Urteilskraft.” In: G. Funke (Hg.), Akten des 7. Internationalen Kant-Kongresses Mainz 1990. 
CAIMI, M. “Über eine wenig beachtete Deduktion der regulativen Ideen”, in: KantStudien, Bd. 86, Hft. 3 (1995), 308-320.

CALOSI, C. e GRAZIANI, P. (eds.) Mereology and the Sciences: Parts and Wholes in the Contemporary Scientific Context. Springer International Publishing, 2014.

CANGUILHEM, G. Idéologie et rationalité dans l'histoire des sciences de la vie, Vrin, Paris, 1981. La Connaissance de la vie, Paris, J. VRIN, 1989.

CHEUNG, T. Die Organisation des Lebendigen: Zur Entstehung des biologischen Organismusbegriffs bei Cuvier, Leibniz und Kant, Campus Verlag, 2000.

CHEUNG, T. "From the organism of a body to the body of an organism: occurrence and meaning of the word 'organism' from the seventeenth to the nineteenth centuries”. BJHS 39(3): 319-339, September 2006.

CHEUNG, T. "Der Baum im Baum: Modellkörper, reproduktive Systeme und die Differenz zwischen Lebendigem und Unlebendigem bei Kant und Bonnet.” In E.-O. Onnasch (Ed.), Kants Philosophie der Natur: ihre Entwicklung im 'Opus postumum' und ihre Wirkung (pp. 25-49). Berlin, de Gruyter.

DEMAREST, B. “Kant's epigenesis: specificity and developmental constraints". Springer, HPLS (2017) 39:3.

DÖRFLINGER, B. Das Leben theoretischer Vernunft, de Gruyter, Berlin, 2000.

DUCHESNEAU, F. Leibniz: le vivant et l'organisme, VRIN, Paris, 2010. . "HALLER ET LES THÉORIES DE BUFFON ET C. F. WOLFF

SUR L'ÉPIGENÈSE”. in History and Philosophy of the Life Sciences, Vol. 1, No. 1 (1979), pp. 65-100. 
. "Du modèle cartésien au modèle spinoziste de l'être vivant." in

Canadian Journal of Philosophy, Vol. 3, No. 4 (Jun., 1974), pp. 539-562.

Duchesneau, F e Justin E. H. Smith The Leibniz-Stahl Controversy. Yale University Press, 2016.

DÜSING, K. “Teleologie und natürlicher Weltbegriff. Untersuchungen zu Strukturen der alltäglichen Erfahrungswelt.” In: Neue Hefte für Philosophie 20, S.31-59. 1981

. Die Teleologie in Kants Weltbegriff. Bonn, 1986

. "Beauty as the Transition from Nature to Freedom in Kant's Critique of Judgment.” In: Noûs 24, S. 79-92. 1990

EMUNDTS, Dina, Das Problem der Organismen in Kants Kritik der Urteilskraft und im Nachlasswerk, in Kant und die Berliner Aufklärung, Band IV, org. Gerhardt, V., Horstmann, R., Schumacher, R,. de Gruyter, Berlin, 2001.

ENSKAT, R. (eds.) Wissenschaft und Aufklärung. VS Verlag für Sozialwissenschaften, 1997.

ENSKAT, R. Bedingungen der Aufklärung: Philosophische Untersuchungen zu einer Aufgabe der Urteilskraft. Velbrück Wissenschaft 2008

FELLBAUM, A. "Kants Organismusbegriff und seine Transformation in der Naturphilosophie F. W. J.Schellings" in Archiv für Begriffsgeschichte, Vol. 47 (2005), pp. 215-223

FRIEDLANDER, E. Expressions of Judgment: An Essay on Kant's Aesthetics. Harvard University Press, 2015.

FÖRSTER, E. Kant's final synthesis: an essay on the Opus postumum. Harvard University Press, 2000. 
FRIEDMAN, M. Kant's Construction of Nature: A Reading of the Metaphysical Foundations of Natural Science. Cambridge University Press, 2013.

FUGATE, C. D. The Teleology of Reason: A Study of the Structure of Kant's Critical Philosophy. Walter de Gruyter, Berlin/Boston, 2014.

GAISSINOVICH, A. E. "Le rôle du Newtonianisme dans la renaissance des idées épig[enetiques en embryologie du XVIIIe siécle.” In Actes du XIe Congress International d'Histoire des Sciences (Vol. 5, pp. 105-110). 1968.

GENOVA, A. C. "Kant's epigenesis of pure reason". Kant-Studien, Berlin, 65, p. 259-73, 1974.

GIANNOTTI, José Arthur. "Kant e o espaço da história universal". In: Discurso. Departamento de Filosofia da FFLCH da USP, São Paulo, v. 32, p. 193-234, 2002.

GINSBORG, H. "Two Kinds of Mechanical Inexplicability in Kant and Aristotle". In: Journal of the History of Philosophy 42.1. 2004, 35-7.

GINSBORG, H. The Normativity of Nature: Essays on Kant's Critique of Judgement. Oxford University Press, UK, 2015.

GLOY, K. "Organologische Technik oder technische Natürlichkeit? Das Programm einer Einheit von Technik und Natur." In: Deutsche Zeitschrift für Philosophie 40, S. 490-502. 1992.

GOTTELF, A. Teleology, First Principles, and Scientific Method in Aristotle's Biology. Oxford University Press, 2012.

GOY, I. e WATKINS, E. Kant's Theory of Biology, De Gruyter, 2013.

GOY, I. Kants Theorie der Biologie: Ein Kommentar. Eine Lesart. Eine historische Einordnung. Walter de Gruyter, 2016. 
GUYER, P. Kant's Critique of the Power of Judgment: Critical Essays. Rowman \& Littlefield Publishers, Maryland, 2003.

HALL, B. The Post-Critical Kant: Understanding the Critical Philosophy through the Opus Postumum. Routledge, 2014.

HEIDEMANN, D.H. (ed.) Teleology. Walter de Gruyter · Berlin · New York, Kant Yearbook, 1/2009.

HENRICH, Dieter. "Kant's Notion of the Deduction". In: FÖRSTER, Eckart. Kant's Transcendental Deductions. The three 'Critiques' and the 'Opus Posthumum'. Stanford: Stanford University Press, 1989.

HÖFFE, O. (org.) Immanuel Kant: Kritik der Urteilskraft, Akademie Verlag, Berlin, 2008.

HUNEMAN, P. La critique du jugement biologique et l'a-métaphysique du vivant, in Recht und Frieden in der Philosophie Kants, Band 3, org. Rohden, V., Terra, R. R., Almeida, G. A., Ruffing, M., de Gruyter, 2008, Berlin. Métaphysique et Biologie: Kant et la constitution du concept d’organisme. Kimé, Paris, 2008.

Understanding Purpose: Kant and the Philosophy of Biology, University of Rochester Press, 2007.

INGENSIEP, H. W. Die biologischen Analogien und die erkenntnistheoretischen Alternativen in Kants Kritik der reinen Vernunt $B \S 27$, Kant-Studien 85. Jahrg., Walter de Gruyter 1994, S. 381-393.

. "Organism, epigenesis, and life in Kant's thinking e Biophilosophy between transcendental philosophy, intuitive analogy, and empirical ontology.” Annals of the History and Philosophy of Biology, 11, 59-84, 2006. 
ISHIKAWA, F. Kants Denken von einem Dritten: das Gerichtshof-Modell und das unendliche Urteil in der Antinomielehre. Verlag Peter Lang, Frankfurt am Main, 1990.

JENG, J-J. Natur und Freiheit: Eine Untersuchung zu Kants Theorie der Urteilskraft, Editions Rodopi B.V., Amsterdam - New York, NY 2004.

JONAS, H. Organismus und Freiheit. Ansätze zu einer philosophischen Biologie. Vandenhoeck \& Ruprecht in Göttingen.

KAULBACH, F. "Kants Metaphysik der Natur, Weltidee und Prinzip der Handlung bei Kant." in Zeitschrift für philosophische Forschung, Bd. 30, H. 3 (Jul. Sep., 1976), pp. 329-349

KLIMMEK, N. F. Kants System der transzendentalen Ideen. Walter de Gruyter • Berlin · New York, 2005.

Kreines, J. (2005). The inexplicability of Kant's Naturzweck: Kant on teleology, explanation and biology. Archiv für Geschichte der Philosopohie, 87, 270311.

KROHN, W.; KÜPPERS, G.; NOWOTNY, H. (eds.) Selforganization: Portrait of a Scientific Revolution. Springer, 1990.

KUGELSTADT, M. Synthetische Reflexion: zur Stellung einer nach Kategorien reflektierenden Urteilskraft in Kants theoretischer Philosophie, Walter de Gruyter, Berlin, 1998.

KÖCHY, K. et al. Annals of the History and Philosophy of Biology, Volume 11 (2006) Universitätsverlag Göttingen, 2007.

LEBRUN, G. Kant e o fim da metafísica, trad. Carlos Alberto Ribeiro de Moura, $1^{\text {a }}$ edição, Martins Fontes Editora, São Paulo, 1993. 
LEHMANN, Gerhard. Beiträge zur Geschichte und Interpretation der Philosophie Kants, de Gryuter, Berlin, 1969.

Lenoir. (1989). The strategy of Life: Teleology and mechanism in nineteenth-century biology, 1982; 2nd ed. Chicago/London: University of Chicago Press.

LORD, B. Kant's Productive Ontology: Knowledge, Nature and the Meaning of Being. THESIS, University of Warwick, Department of Philosophy, 2003.

Lovejoy, A. O. The Great Chain of Being: A Study of the History of an Idea. Harvard University Press, 1936.

LÖW, R. Die Philosophie des Lebendigen. Der Begriff des Organischen bei Kant, sein Grund und seine Aktualität. Suhrkamp, Frankfurt, 1980.

MAKKREEL, R. A. "Regulative and Reflective Uses of Purposiveness in Kant". In: H. Robinson (Ed.), System and Teleology in Kant's Critique of Judgment. Spindel Conference 1991. The Southern Journal of Philosophy XXX, Supplement, S. 49-63. 1991

MARQUES, U. R. A. (org.) Kant e a Biologia. Barcarola, São Paulo, 2012.

MARQUES, A. Organismo e sistema em Kant. Editorial Presença, Lisboa, . A razão judicativa, Imprensa Nacional-Casa da Moeda, 2004.

MARTINS, C. A. "Die Antinomie zwischen Mechanismus und Finalismus in den spekulativen Überlegungen über die Natur", Studia Philosophica Kantiana $2 / 2013$

McLAUGHLIN, P. Kant's critique of teleology in biological explanation: Antinomy and teleology. Lewiston: Mellen. (1990).

MENSCH, J. Kant's Organicism: Epigenesis and the Development of Critical Philosophy. University of Chicago Press, 2013. 
MENZER, P. Kants Lehre von der Entwicklung in Natur und Geschichte, Druck und Verlag von Georg Reimer, Berlin, 1911.

MODEL, A. Metaphysik und reflektierende Urteilskraft bei Kant Untersuchungen zur Transformierung des leibnizschen Monadenbegriffs in der Kritik der Urteilskraft, Frankfurt am Main, Athenaüm, 1987.

MODEL, A. "Kant und die Medizin der Aufklärung" IN Sudhoffs Archiv, Bd. 74, H. 1 (1990), pp. 112-116

MORAN, K. A. Community and Progress in Kant's Moral Philosophy. The Catholic University of America Press, 2012.

MÜLLER-SIEVERS, H. Self-generation: Biology, philosophy and literature around 1800. Stanford: Stanford University Press, 1997.

Panchen, A. L. Classification, evolution and the nature of biology, Cambridge University Press, NY, 1992.

PETER, J. Das transzendentale Prinzip der Urteilskraft: eine Untersuchung zur Funktion und Struktur Der Reflektierenden Urteilskraft Bei Kant, Walter de Gruyter, 1992.

PIMENTA, P. P. G. "Reflexão e finalidade: a finitude da razão na Crítica do Juízo teleológico de Kant." in Discurso. Departamento de Filosofia da FFLCH da USP, São Paulo, v. 32, p. 193-234, 2002.

Pinto-Correia, C. (1997). The ovary of eve: Egg and sperm and preformation. Chicago/ London: University of Chicago Press.

POLLOK, K.. Kants 'Metaphysische Anfangsgründe der Naturwissenschaft': Eine Kritischer Kommentar, Hamburg, Felix Meiner Verlag, 2001.

PUECH, Michel. Kant et la causalité: étude sur la formation du système critique. Paris, Vrin, 1990. 
QUARFFOOD, M. Transcendental Idealism and the Organism, Akademitryck AB, Edsbruk, 2004.

Richards, R. A. Biological Classification: A Philosophical Introduction. Cambridge University Press, Cambridge, 2016.

SCHLÜTER, Hermann: Die Wissenschaften vom Leben zwischen Physik und Metaphysik. Auf der Such nach dem Newton der Biologie im 19. Jahrhundert (Schriften zur Naturphilosophie, Bd. 1), Weinheim 1985.

RAEDLER, S. Kant and the Interests of Reason. Walter de GruyteR, Berlin, 2015.

RANG, B. "Naturnotwendigkeit und Freiheit.” In: Kantstudien 81, S. 24-56. 1990

RIEDEL, M. Urteilskraft und Vernunft. Kants ursprüngliche Fragestellung, Frankfurt a.M. 1989

ROHS, P. "Kants Prinzip der durchgängigen Bestimmung alles Seienden." In: Kantstudien 69, S. 170-180. 1991

. "Die Vermittlung von Natur und Freiheit in Kants Kritik der Urteilskraft".

In: G. Funke (Hg.), Akten des 7. Internationalen Kant-Kongresses Mainz Bonn, Bd. I, S. 213-234. 1990.

SCHÜSSLER, I. "Le problème de la nature organique dans la Critique de la faculté de juger de Kant.” In Kant Actuel: Hommage à Pierre Laberge, VRIN, Paris, 2000.

SCHIEMANN, G. “Totalität oder Zweckmäßigkeit? Kants Ringen mit dem Mannigfaltigen der Erfahrung im Ausgang der Vernunftkritik”. In: Kantstudien 83, S. 294-303. 1992

SIMON, J. "Teleologisches Reflektieren und kausales Bestimmen”. In: Zeitschrift für philosophische Forschung 30, S. 369-388.1976 
SHELL, S. M. The Embodiment of Reason: Kant on Spirit, Generation, and Community. University of Chicago Press, 1996.

SLOAN, P. "Preforming the categories: Kant and eighteenth-century generation theory." Journal of the History of Philosophy, 2, 229-253, 2002.

TANAKA, M. Kants Kritik der Urteilskraft und das Opus postumum: Probleme der Deduktion und ihre Folgen. Thesis, Philipps-Universität Marburg, 2004.

TERRA, Ricardo. Passagens: estudos sobre a filosofia de Kant, Editora UFRJ, 2003.

Teufel, T. (2014). The impossibility of a 'Newton of the blade of grass' in Kant's teleology. In O. Nachtomy, \& J. E. H. Smith (Eds.), The life sciences in early modern philosophy (pp. 47-61). Oxford: Oxford University Press.

TIPTON, J.A. Philosophical Biology in Aristotle's Parts of Animals. Springer International Publishing, 2014.

TONELLI, G. "La formazione del testo della 'Kritik der Urteilskraft"” in Revue Internationale de Philosophie, Vol. 8, No. 30 (4) (1954), pp. 423-448

TUSCHLING, B. “System des transzendentalen Idealismus bei Kant? Offene Fragen der - und an die - Kritik der Urteilskraft" In: Kantstudien 86, S. 196-210. 1995.

UNGERER, E. Die Teleologie Kants und ihre Bedeutung für die Logik der Biologie, Verlag von Gebrüder Borntraeger, Berlin, 1922.

Vicq-d'Azyr, Felix. Discours sur l'anatomie in Oeuvres de Vicq-D'Azyr, Imprimerie de Baudouin, Paris, 1805, Tomo IV.

VUILLEMIN, J. Physique et Metaphysique Kantiennes. PUF, 1987.

WUBNIG, J. “The epigenesis of pure reason.” Kant-Studien, 60, 147-152, 1968/69. ZAMITTO, J. “Teleology Then and Now: the Question of Kant's Relevance for Contemporary Controversies over Function in Biology”. In: Studies in 
History and Philosophy of Biological and Biomedical Sciences 37.4. 2006, 759.

"'This inscrutable principle of an original organization': epigenesis and 'looseness of fit' in Kant's philosophy of science". Stud. Hist. Phil. Sci. 34 (2003) 73-109. . "Epigenesis in Kant: Recent reconsiderations" in Studies in History and Philosophy of Science 58 (2016) 85-97, 2016.

ZANNETTI, Veronique, Die Antinomie der teleologischen Urteilskraft, KantStudien 83. Jahrg., Walter de Gruyter 1993, S. 341-355.

ZEDLER, J. H. Grosses vollständiges Universal-Lexicon Aller Wissenschafften und Künste, Halle, 1732 - 1754.

ZUCKERT, R. Kant on Beauty and Biology: An Interpretation of the 'Critique of Judgment'. Cambridge University Press, 2007.

ZUMBACH, C. The Transcendent Science: Kant's Conception of Biological Methodology, Martinus Nijhoff Publishers, Hague, 1984. 